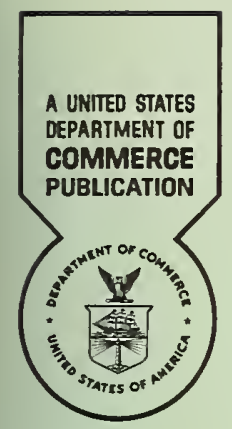

National Burexy of ctandard's

Library, E-01 Adnin. Bldg.

\title{
BIBLIOGRAPHY ON THE
}

\section{HIGH TEMPERATURE CHEMISTRY}

\section{AND PHYSICS OF MATERIALS}




\section{NATIONAL BUREAU OF STANDARDS}

The National Bureau of Standards ' was established by an act of Congress March 3, 1901. Today, in addition to serving as the Nation's central measurement laboratory, the Bureau is a principal focal point in the Federal Government for assuring maximum application of the physical and engineering sciences to the advancement of technology in industry and commerce. To this end the Bureau conducts research and provides central national services in four broad program areas. These are: (1) basic measurements and standards, (2) materials measurements and standards, (3) technological measurements and standards, and (4) transfer of technology.

The Bureau comprises the Institute for Basic Standards, the Institute for Materials Research, the Institute for Applied Technology, the Center for Radiation Research, the Center for Computer Sciences and Technology, and the Office for Information Programs.

THE INSTITUTE FOR BASIC STANDARDS provides the central basis within the United States of a complete and consistent system of physical measurement; coordinates that system with measurement systems of other nations; and furnishes essential services leading to accurate and uniform physical measurements throughout the Nation's scientific community, industry, and commerce. The Institute consists of an Office of Measurement Services and the following technical divisions:

Applied Mathematics-Electricity-Metrology-Mechanics-Heat-Atomic and Molecular Physics-Radio Physics "-Radio Engineering "-Time and Frequency "-Astrophysics "-Cryogenics."

THE INSTITUTE FOR MATERIALS RESEARCH conducts materials research leading to improved methods of measurement standards, and data on the properties of well-characterized materials needed by industry, commerce, educational institutions, and Government; develops, produces, and distributes standard reference materials; relates the physical and chemical properties of materials to their behavior and their interaction with their environments; and provides advisory and research services to other Government agencies. The Institute consists of an Office of Standard Reference Materials and the following divisions:

Analytical Chemistry-Polymers-Metallurgy_-Inorganic Materials_Physical Chemistry.

THE INSTITUTE FOR APPLIED TECHNOLOGY provides technical services to promote the use of available technology and to facilitate technological innovation in industry and Government; cooperates with public and private organizations in the development of technological standards, and test methodologies; and provides advisory and research services for Federal, state, and local government agencies. The Institute consists of the following technical divisions and offices:

Engineering Standards-Weights and Measures - Invention and Innovation - Vehicle Systems Research-Product Evaluation-Building Research-Instrument Shops-Measurement Engineering-Electronic Technology-Technical Analysis.

THE CENTER FOR RADIATION RESEARCH engages in research, measurement, and application of radiation to the solution of Bureau mission problems and the problems of other agencies and institutions. The Center consists of the following divisions:

Reactor Radiation-Linac Radiation-Nuclear Radiation-Applied Radiation.

THE CENTER FOR COMPUTER SCIENCES AND TECHNOLOGY conducts research and provides technical services designed to aid Government agencies in the selection, acquisition, and effective use of automatic data processing equipment; and serves as the principal focus for the development of Federal standards for automatic data processing equipment, techniques, and computer languages. The Center consists of the following offices and divisions:

Information Processing Standards-Computer Information - Computer Services - Systems Development-Information Processing Technology.

THE OFFICE FOR INFORMATION PROGRAMS promotes optimum dissemination and accessibility of scientific information generated within NBS and other agencies of the Federal government; promotes the development of the National Standard Reference Data System and a system of information analysis centers dealing with the broader aspects of the National Measurement System, and provides appropriate services to ensure that the NBS staff has optimum accessibility to the scientific information of the world. The Office consists of the following organizational units:

Office of Standard Reference Data-Clearinghouse for Federal Scientific and Technical Information "-Office of Technical Information and Publications-Library-Office of Public Information-Office of International Relations.

Headquarters and Laboratories at Gaithersburg, Maryland, unless otherwise noted; mailing address Washington, D.C. 20234.
Located at Boulder, Colorado 80302. 


\title{
BIBLIOGRAPHY ON THE HIGH TEMPERATURE CHEMISTRY AND PHYSICS OF MATERIALS
}

\author{
April, May, June \\ 1969
}

\author{
J. J. Diamond, Editor \\ Institute for Materials Research \\ National Bureau of Standards \\ Washington, D. C. 20234
}

Under the auspices of the

International Union of Pure and Applied Chemistry

Commission on High Temperatures and Refractories

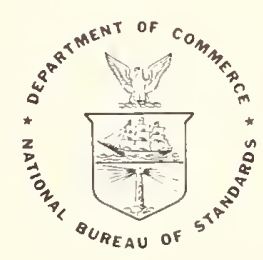

U. S, National Bureau of Standards, Special Publication 315-2

Nat. Bur. Stand. (U.S.), Spec. Publ. 315-2, 74 pages (July 1969) CODEN : XNBSA

Issued July 1969 
VAATIONAL B'RE-'US OF STAMDAFIDS

FEB 271970

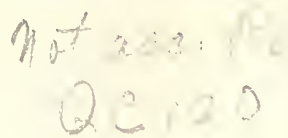

$N_{0}, 3 / 5-2$

1964

enter 1 .

Library of Congress Catalog Card Number: 77-600413 


\section{Contributors}

\section{PART I. Compiled by}

N. F. H. Bright, Department of Energy, Mines and Resources, Ottawa, O ntario, Canada. J. J. Diamond, National Bureau of Standards, Washington, D. C., U.S.A.

H. Flood, Norwegian Institute of Technology, Trondheim, Norway.

M. Foex, C.N.R.S., Super-Refractories Laboratory, Odeillo, France.

M. G. Hocking, Imperial Ccllege of Science and Technology, London, England.

H. Mii, University of Nagoya, Nagoya, Japan.

H. Nowotny, University of Vienna, Vienna, Austria.

A. Wittmann, Vienna Institute of Technology, Vienna, Austria.

\section{PART II. Compiled by}

L. Brewer, University of California, Berkeley, California, U.S.A. 


\section{Contents}

\section{PART I. Solids and Liquids}

A. Devices for achieving temperatures above $1500{ }^{\circ} \mathrm{C}$

B. Devices for measuring and controlling temperatures above $1500{ }^{\circ} \mathrm{C}$

C. Devices for physical measurements at temperatures above $1000{ }^{\circ} \mathrm{C}$

D. Thermodynamic properties, at temperatures below $1000{ }^{\circ} \mathrm{C}$, of materials which melt above $1500{ }^{\circ} \mathrm{C}$

E. Properties, at temperatures above $1000{ }^{\circ} \mathrm{C}$, of materials which melt above $1500{ }^{\circ} \mathrm{C} \ldots \ldots$

a. Metallic materials _.

b. Non-metallic materials _-_. 9

c. Mixed materials _-_- 15

F. Properties, at temperatures above $1000{ }^{\circ} \mathrm{C}$, of materials which melt below $1500{ }^{\circ} \mathrm{C} \ldots$

a. Metallic materials _- 15

b. Non-metallic materials _- 17

c. Mixed materials _-_-_-_- 21

G. Phase equilibria above $1000{ }^{\circ} \mathrm{C}$

$\mathrm{H}$. Reactions at temperatures above $1000{ }^{\circ} \mathrm{C}$

I. Books _-_

\section{PART II. Gases}

A. Spectroscopy of interest to high temperature chemistry

B. Reactions between gases and condensed phases 
This is one of a series of current-awareness bibliographies on high-temperature chemistry and physics published under the auspices of the Commission on High Temperatures and Refractories of the International Union of Pure and Applied Chemistry. The first issue covered the period October-December 1957 and, with several changes in title, format and content, the series has appeared quarterly since that time. It acquired its present format and status as a National Bureau of Standards publication with the issue covering the fourth quarter of 1968 .

It is compiled by an International Working Group on Bibliographies, attached to the Commission, consisting of about fifteen scientists . Part I is compiled by the Contributors scanning the pertinent journals published in their countries and in some cases, of adjacent countries, while the literature of other countries is covered by the editor, mainly from published lists of tables of contents. Part II is obtained by searching Chemical Abstracts.

With very few exceptions, abbreviations of journal names follow the usage of Chemical Abstracts. Journal names using non-Roman alphabets are transliterated when the original is being referenced. In those cases were translation journals are referenced its name and pagination are used.

All titles are translated into English. Translations are by the contributors, the editor, Chemical Abstracts, or those published in table of contents lists. 

Bibliography on the High Temperature Chemistry and Physics of Materials

$$
\begin{aligned}
& \text { April, May, June } 1969 \\
& \text { J. J. Diamond, Editor }
\end{aligned}
$$

The bibliography consists of references to research involving temperatures above $1000{ }^{\circ} \mathrm{C}$, which were noted by the Contributors during the above three-month period. Since this is intended primarily as a current-awareness bibliography, there is no cross-referencing or indexing. This issue contains about 700 references roughly grouped under fifteen subject headings .

Key words: Bibliography, high temperature; chemistry, high temperature; high temperature chemistry; materials properties; research at high temperatures; thermophysical properties.

\section{Part I. SOLIDS AND LIQUIDS}

A. Devices for achieving temperatures above $1500^{\circ} \mathrm{C}$

1. A laboratory arc melter

S. Arajs and G. P. Wray (E. C. Bain Lab., U. S. Steel Res. Ctr., Monroeville, $\mathrm{Pa}$. )

Carbon 2, 518-20 (1969)

2. Direct determination of oxygen in oxide materials

W. Koch and H. Lemm (Chem. Lab., August Thyssen-Hütte AG, DuisburgHamborn, Germ.)

Arch. Eisenhüttenw. 39, 823-27 (1968)

3. An apparatus for floating zone melting of refractory metals by electron bombardment

K. Masumoto and Y. Tamura (Nat. Res. Inst. Met., Meguro-ku, Tokyo)

Nippon Kinzoku Gakkai Shi 32 [11], 1121-27 (1968)

4. Centrifugal liquid wall furnace

B. Selton and J. A. Sheward (Nat. Phys. Lab., Teddington, U. K.)

J. Mater. Sci. 4, 302-09 (1969)

5. Obtention of nigh temperatures from combustion products for heat and electric power plants with magnetohydrodynamic generators

B. Ya. Shumyatski, L. K. Khokhlov, A. G. Sokolskii and A. P. Rogachev

Teplofiz. Vys. Temp. $\underline{Z}[2], 342-48$ (1969) 
B. Devices for measuring and controlling temperatures above $1500{ }^{\circ} \mathrm{C}$

1. Pt metals in the measurement of temperature: The new international temperature scale of 1968

C. R. Barber

Platinum Metals Rev. 13, 65-67 (1969)

2. Radiation pyrometers as high temperature control sensors in the iron and steel industry

L. C. Bogan and J. Mills (BHP Res. Lab., Shortland, Solomon)

Austra1. J. Instrum. Control 25 [1], 35 (1969)

3. Sound ways to measure temperature

L. C. Lynnworth (Panametrics, Inc., Waltham, Mass.)

Instrum. Technol. 16 [4], 47-52 (Apri1 1969)

4. Oxide thermistor for use to $2500 \mathrm{~K}$

E. G. Wolff (Avco Space Systems Div., Lowell, Mass. 01851)

Rev. Sci. Instr. 40 [4], 544-49 (1969)

5. A Rh-Pt probe for flame velocity measurement

Anonymous

Platinum Metals Rev. 13, 56 (1969)

6. Thermocouples under neutron bombardment

Anonymous

Platinum Metals Rev. 13, 64 (1969)

C. Devices for physical measurements at temperatures above $1000^{\circ} \mathrm{C}$

1. An electron beam technique for measuring thermal conductivity

R. D. Allen (Donald W. Douglas Labs., Richland, Wash.)

Am. Ceram. Soc. Bull. 48 [6], 614-17 (1969)

2. Vacuum chamber for an $x$-ray diffractometer for investigating hightemperature processes

V. I. Babenko, V. V. Levitin, V. A. Kravchenko and A. A. Serebrennikov Pribory Tekh. Eksper. [1], 189 (1969)

3. Determination of the impact strength of carbon-graphite materials at high temperatures

V. N. Barabanov, V. I. Strokov and G. G. Zaitsev

Zavod. Lab. 35 [3], 338-40 (1969)

4. Thermobalance protection from corrosive atmospheres

N. Birks and N. Tattam (Met. Dept., Univ. of Sheffield, U. K.)

J. Sc1. Instr. (Ser. 2) 2 , 628-29 (1969)

5. Furnaces with low thermal gradients for molten salt spectropnotometry C. R. Boston and G. P. Smith (Oak Ridge Nat. Lab., Oak Ridge, Tenn.)

J. Sci. Instr. (Ser. 2) 2 , 543-46 (1969) 
C. 6. Thermodynamic properties of metal oxides from emf measurements using solid electrolytes

G. G. Charette (Univ. of Toronto, 1967)

Dissertation Abstr. 29B [8], 2823-24 (1968-69)

7. Determination of vaporization rate of liquids and solids at low vapor pressures

H. Cordes and N. Cammenga

Z. Phys. Chem. (Frankfurt am Main) 63 [5-6], 280-96 (1969)

8. Potassium resistance test for refractories intended for use in blast furnaces

M. Esnoult and A. Auerbach (Res. Lab. I'Electro-Refract., 84 Le Pontet, Fr.)

J. Iron Steel Inst. (London) 374 (1969)

9. A 77-1300 $\mathrm{K}$ single crystal $\mathrm{x}$-ray specimen chamber

P. C. Gehlen (Battelle Mem. Inst., Columbus, Ohio 43201)

Rev. Sci. Instr. 40 [5], 715-18 (1969)

10. Liquid encapsulation technique for determination of melt vapour pressures

S. E. R. Hiscocks

J. Sci. Instr. (Ser. 2) 2 , 417-18 (1969)

11. Surface-tension techniques for molten salts

G. J. Janz, J. Wong and G. R. Lakshminarayanan (Rensselaer Polytech. Inst., Chem. Dept., Troy, N. Y. 12181)

Chem. Instrum. 1 [3], 261-72 (1969)

12. A vacuum hot-press for toxic materials

J. W. Kelly (Australian A.E.C., Lucas Heights, N.S.W.)

J. Sc1. Instr. (Ser. 2) 2, 369-70 (1969)

13. Universal machine for testing materials at temperatures up to $2000{ }^{\circ} \mathrm{C}$

M. V. Klassen-Neklyudova and 5 others

Zavod. Lab. 35 [4], 507-08 (1969)

14. Application of beam-bending method to measurement of glass viscosity in the range of $10^{7}-10^{16}$ poises

K. Kobayashi and R. Yokota (Ctr. Res. Lab., Tokyo Shibaura Elect. Co., Kawasaki, Japan)

Yogyo Kyokai Shi $\underline{76}$ [875], 218-23 (1968)

15. Improved methods of determining thermal effects during thermographic analysis in the range -180 to $1600{ }^{\circ} \mathrm{C}$

V. Z. Kolodyazhnyi, A. I. Zhemarkin and A. M. Kuchumov (Kurnakov Gen. \& Inorg. Chem. Inst., Moscow)

Zh. Neorg. KhIm. 14 [4], 1057-61 (1969) 
C. 16. System for investigation of vaporizability of high-melting metals and alloys

N. S. Kudryavtsev and L. I. Ivanov

Zavod. Lab. 35 [3], 368-69 (1969)

17. System for dynamic measurement of hardness at temperatures up to $2700{ }^{\circ} \mathrm{C}$ in vacuum

A. A. Kulbakh, V. M. Shchavelin and N. A. Evstyukhin

Zavod. Lab. 35 [3], 360-61 (1969)

18. Recording the electrical resistance of a specimen during testing for fatigue in vacuo at high temperature M. G. Lozinski1, V. A. Marichev, V. V. Afonskaya and A. V. Klimov Zavod. Lab. 35 [3], 341-42 (1969)

19. High temperature isoteniscope for serial measurements

D. K. W. Schulze

Chem. Tech. (Berlin) 21 [4], 232-33 (1969)

20. System for measuring the hardness of alloys at high temperatures

P. I. Talanov, N. N. Yakushin, Yu. E. Abramenko and L. N. Mikhalchenko

Zavod. Lab. 35 [3], 358-59 (1969)

21. On the dilatometer for studying sintering process and its applications

K. Tamura and Y. Muramatsu (Nat. Res. Inst. Met., Meguro-ku, Tokyo) Rept. Nat. Res. Inst. Met. 11 [4], 85-92 (1968)

22. A steady-state gas-liquid metal diffusion celI

L. R. Vel ho, N. M. El-Tayeb, J. Gani and N. A. D. Parlee (Miner. Eng. Dept., Stanford Univ., Stanford, Calif.)

Trans. Met. Soc. AIME 245 [1], 184-86 (1969)

23. Measurements of heats of mixing in liquid alloys with the adiabatic calorimeter

A. Yazawa, T. Kawashima and K. Itagaki (Res. Inst. Miner. Dressing and Met., Tohoku Univ., Senda1, Japan)

Nippon Kinzoku Gakkai Shi 32 [12], 1281-87 (1968)

D. Thermodynamic properties, at temperatures below $1000^{\circ} \mathrm{C}$, of materials which melt above $1500^{\circ} \mathrm{C}$

1. Enthalpy of formation of zirconium carbide

F. B. Baker, E. K. Storms and C. E. Holley, Jr. (Los Alamos Sci. Lab., Los Alamos, N. M. 87544)

J. Chem. Eng. Data 14 [2], 244-46 (1969)

2. Specific heat of CdS, CdSe, and CdTe at 55-300 ${ }^{\circ} \mathrm{K}$

A. F. Demidenko

Izv. Akad. Nauk SSSR, Neorg. Mater. 5 [2], 252-55 (1969) 
D. 3. Thermodynamic properties of manganese silicides

V. N. Eremenko, G. M. Luka shenko and V. R. Sidorko

Porosh. Met. $\underline{9}[2], 74-76$ (Feb. 1969)

4. $\mathrm{BaFe}_{2} \mathrm{O}_{4}$ enthalpy and heat capacity in the range $25-1000{ }^{\circ} \mathrm{C}$

N. A. Landiya, T. A. Pavlenishvili and G. D. Chachanidze (Acad. Sci., Inst. Inorg. Chem. \& Electrochem., Tblisi, GeSSR)

Zh. Fiz. Khim. 43 [4], 1002-03 (1969)

5. Enthalpies of formation of some tungstates, $\mathrm{MWO}_{4}$

A. Navrotsky and 0 . J. Kleppa (Chem. Dept. and James Franck Inst., Univ. of Chicago, I11. 60637)

Inorg. Chem. $\underline{8}$ [4], 756-58 (1969)

6. Low temperature specific heat of some rare-earth orthoferrites

J. Peyrard and J. Sivardiere (CRTBT, Chem. Martyrs, Grenoble, Fr.)

Solid State Commun. 7 [8], 605-10 (1969)

7. Specific heat and paramagnetic susceptibility of stoichiometric and reduced rutile $\left(\mathrm{TiO}_{2}\right)$ from 0.3 to $20 \mathrm{~K}$

T. R. Sandin and P. H. Keesom (N. Carolina A \& T State Univ., Greensboro, N. C. 27411)

Phy. Rev. 177 [3], 1370-82 (1969)

8. Low temperature heat capacity of refractory metal borides

Y. S. Tyan, L. E. Toth and Y. A. Chang (Met. Eng. School, Univ. of Minnesota, Minneapolis)

J. Phys. Chem. Solids 30, 785-92 (1969)

9. Effect of crystal lattice imperfections on the thermodynamic properties of solid solutions of wustite with $\mathrm{MgO}$

Yu. P. Vorobev, E. G. Bogacheva, A. N. Men and G. I. Chufarov

Izv. Akad. Nauk SSSR, Neorg. Mater. 5 [2], 394-97 (1969)

10. Free energy of formation of $\mathrm{ZnO}(\mathrm{s})$ for the temperature range 420 to $908^{\circ} \mathrm{C}$

T. C. Wilder (Ledgemont Lab., Kennecott Copper Co., Lexington, Mass.)

Trans. Met. Soc. AIME 245 [6], 1370-72 (1969)

E. Properties, at temperatures above $1000{ }^{\circ} \mathrm{C}$, of materials which melt above $1500{ }^{\circ} \mathrm{C}$

a. Metallic materials

1. Thermodynamics of nonstoichiometric interstitial alloys. I. B in Pd

H. A. Brodowsky and H. J. Schaller (Inst. Phys. Chem., Univ. of Muenster, Germ.)

Trans. Met. Soc. AIME 245 [5], 1015-20 (1969) 
Ea. 2. Vaporization rates of $\mathrm{TI}, \mathrm{Zr}$, $\mathrm{Hf}$ and $\mathrm{Ta}$ carbides at high tempera tures

V. V. Fesenko and A. S. Bolgar

Teplofiz. Vys. Temp. 4 [2], 244-51 (1969)

3. Thermal expansion of zirconium refractory materials

S. K. Filatov, V. A. Frank-Kamenetskii and T. A. Zhuravina

Izv. Akad. Nauk SSSR, Neorg. Mater. 5 [2], 346-51 (1969)

4. Superplasticity in $W-\operatorname{Re}$ alloys

M. Garfinkle, W. R. Witzke and W. D. Klopp (NASA Lewis Res. Ctr., Cleveland, Ohio)

Trans. Met. Soc. AIME 245 [2], 303-08 (1969)

5. Study of the kinetics and mechanisms of vaporization during the fusion of $\mathrm{Zr}-\mathrm{O}$ and $\mathrm{Zr}-\mathrm{Si}$ alloys in an electron-bombardment furnace

G. Grosse, P. Lehr and P. Albert (Ctr. Etudes Chim. Mét., 94-Vitry/ Seine, Fr.)

Rev. Int. Hautes Temp. Réfract. 5, 299 (1968)

6. Temperature coefficients of the work functions of the (110) and (100) surfaces of $W$ single crystals and of polycrystalline $W$ foil

B. J. Hopkins, T.-J. Lee and C. B. Williams (Surface Phys., The Univ., Southampton, Eng1.)

J. App1. Phys. 40 [4], $1728-32$ (1969)

7. On the thermionic emission mechanism of refractory-metal-carbide ca thodes

Kh. S. Kan and B. S. Kulvarskaya

Izv. Akad. Nauk SSSR, Ser. Fiz. 33 [3], 439-44 (1969)

8. Creep of a dispersion strengthened $\mathrm{Nb}$-base alloy

M. J. Klein (Solar Div., Int. Harvester Co., San Diego, Calif.)

Trans. Met. Soc. AIME 245 [6], 1269-74 (1969)

9. Measurement of thermal expansion coefficient of $W$

R. H. Knibbs (AERE, Harwel1, U. K.)

J.Sci. Instr. (Ser. 2) 2, 515-17 (1969)

10. Constitution and magnetic behavior of $\mathrm{Mn}$-In alloys in the solid and liquid states

W. -U. Kopp, 0. Romer and E. Wachte1 (Max Planck-Inst. Metallforsch., Stuttgart, Germ.)

Z. Meta11k。 59, 917-23 (1968)

11. Thermoelectronic emission from certain high-melting materials and prospects of using them as thermocathodes in instruments and systems with a complex gaseous medium

B. S. Kulvarskaya, A. I. Rekova, V. E. Serebrennikova, V. A. Nikolaeva and Kh. S. Kan

Zh. Tekh. Fiz. 39 [1], 175-83 (1969) 
Ea. 12. The enthalpy of solid $\mathrm{W}$ from $2800^{\circ} \mathrm{K}$ to its melting point

L. Leibowitz, M. G. Chasanov and L. W. Mishler (Argonne Nat. Lab., Argonne, II1.)

Trans. Met. Soc. AIME 245 [5], 981-84 (1969)

13. Reflection of a rare-gas beam from a $W$ ribbon at high temperature

H. G. Lintz, A. Pentenero and P. le Goff (E.N.S. Ind. Chim., Univ. Nancy, Fr.)

J. Chim. Phys. 65, 2169 (1968)

14. Kinetics of the vaporization of metal particles in an arc plasma M. A. Luzhnova and Y. D. Raikhbaum

Teplofiz. Vys. Temp. 7 [2], 313-17 (1969)

15. Effect of the gas atmosphere upon the sintering of Pt microspheres

L. F. Norris and G. Parravano (Chem. \& Met. Eng. Dept., Univ. of Michigan, Ann Arbor, Mich.)

Engelhard Ind. Tech. Bull. 9 [4], 129-34 (1968-69)

16. Certain physical properties of sesquicarbides of $\mathrm{Y}, \mathrm{La}, \mathrm{Ce}$ and $\mathrm{Nd}$ Yu. B. Paderno, V. L. Yupko and G. N. Makarenko

Izv. Akad. Nauk SSSR, Neorg. Mater. $\underline{5}$ [2], 386-88 (1969)

17. Total hemispherical emissivity of Re at $1200-2800{ }^{\circ} \mathrm{K}$

V. E. Peletskii and V. P. Druzhinin

Teplofiz. Vys. Temp. $\underline{7}[2], 364-65$ (1969)

18. Total hemispherical emissivity of pyrolytic zirconium carbide

V. A. Petrov, V. Ya. Chekhovskoi, B. K. Dymov and V. S. Kilin

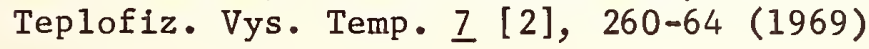

19. Creep of powder metallurgy Re at 0.43 to $0.72 \mathrm{~T}_{\mathrm{m}}$

P. L. Raffo and W. R. Witzke (NASA Lewis Res. Ctr., Cleveland, Ohio)

Trans. Met. Soc. AIME 245 [4], 889-90 (1969)

20. Mechanical behavior of polycrystalline $W$ at elevated temperature

S. L. Robinson and 0. D. Sherry (Mater. Sci. Dept., Stanford Univ., Stanford, Calif.)

Acta Met. 17 [2], 109-25 (1969)

21. Carbide growth in a Mo TZC alloy

N. E. Ryan and J. W. Martin (Met. Dept., Univ. of Oxford, U. K.)

J. Mater. Sci. 4, 471-78 (1969)

22. Electrophysical properties of groups V-VI transition metal disilicides

G. V. Samsonov, V. G. Grebenkina and L. A. Dvorina

Porosh. Met. 9 [4], 42-47 (April 1969)

23. External friction of $\mathrm{Nb}$ and $\mathrm{Ta}$ carbides at high temperatures in vacuo G. V. Samsonov, M. S. Kovalchenko and Yu. G. Tkachenko

Porosh. Met. $\underline{9}$ [2], 49-56 (Feb. 1969) 
Ea. 24. Total normal emissivity of Ta and Hf carbides at $1300-3000^{\circ} \mathrm{K}$ A. E. Sheindlin, V. A. Petrov, A. N. Vinnikova and V. A. Nikolaeva Teplofiz. Vys. Temp. I [2], 257-59 (1969)

25. Thermoelectron emission of (100) faces of single crystals of $W, R e$, Ta, and Mo alloys

N. B. Smirnova, B. G. Smirnov, S. M. Mikha1lov and E. P. Sytaya (Lenin State Univ., Tashkent, UzSSR)

Fiz. Tverd. Tela 11 [4], 962-64 (1969)

26. Thermal conductivity, electrical conductivity, and radiating characteristics of rhodium at high temperatures

A. G. Sorokin, L. N. Trukhanova and L. P. Filippov

Teplofiz. Vys. Temp. I [2], 372-74 (1969)

27. Effect of fabrication variables on the creep-rupture properties of Mo-base alloys

R. L. Stephenson (Oak Ridge Nat. Lab., Oak Ridge, Tenn.)

Trans. Met. Soc. AIME 245 [5], 997-1001 (1969)

28. Knudsen cell studies of the vaporization of samarium dicarbide

N. D. Stout and C. L. Hoenig (Lawrence Rad. Lab., Livermore, Calif. 94550) and P. C. Nordine (Chem. Dept., Univ. Kansas, Lawrence, Kansas 66045)

J. Am. Ceram. Soc. 52 [3], 145-51 (1969)

29. Activity of oxygen in 1iquid Fe-Au alloys

E. S. Tankins (Naval Air Devel. Ctr., Johnsville, Warminster, Pa.) Trans. Met. Soc. AIME 245 [5], 1141-43 (1969)

30. Separation and purification of the rare earth metals by vacuum distillation

F. Trombe and G. Malé (Lab. Terres Rares, 92-Bellevue, Fr.)

Rev. Int. Hautes Temp. Réfract. 5, 287 (1968)

31. Role of the rare earth metals in the purification of $\mathrm{Nb}$

F. Trombe and G. Malé (Lab. Terres Rares, 92-Bellevue, Fr.)

Rev. Int. Hautes Temp. Réfract. 5, 295 (1968)

32. High-temperature plastic deformation of polycrystalline $\operatorname{Re}$

R. R. Vandervoort and $W$. I. Barmore (Lawrence Rad. Lab., Livermore, Calif.)

Trans. Met. Soc. AIME 245 [4], 825-29 (1969)

33. Tungsten filament Iffe under constant-current heating

A. D. WiIson (IBM, Systems Devel. Div., Endicott, N. Y. 13760)

J.App1. Phys. 40 [4], 1956-64 (1969)

34. On the creep-rupture strength of Mo composite cast with some heat-resistant alloys

R. Yoda and T. Aral (Nat. Res. Inst. Met., Meguro-ku, Tokyo) Nippon Kinzoku Gakka1 Shi 32 [9], 836-41 (1968) 
Ea. 35. Deformation of refractory metals and alloys in vacuo at high temperatures

A. M. Zakharov and I. I. Druzhinin

Izv. Vyssh. Ucheb. Zaved., Tsvet. Met. 12 [2], 135-38 (Mar.-Apr. 1969)

36. Temperature and heat conductivity of $\mathrm{Pd}$ at high temperatures

V. E. Zinovev, R. P. Krentsis and P. V. Geld (Kirov Polytech. Inst., Sverdlovsk, USSR)

Fiz. Tverd. Tela 11 [3], 834-35 (1969)

b. Non-metallic materials

1. A thermodynamic study of the urania-uranium system

R. J. Ackermann, E. G. Rauh and M. S. Chandrasekharalah (Argonne Nat. Lab., Argonne, I11. 60439)

J. Phys. Chem. 73 [4], 762-69 (1969)

2. High temperature chemistry of simple metallic oxides

C. B. Alcock

Chem. Brit. $\underline{5}$ [5], 216-23 (1969)

3. Kinetics of the sintering of $\mathrm{ZrO}_{2}$

N. A. Andreeva, V. M. Gropyanov and L. V. Kozlovskii

Ogneupory 34 [5], 51-57 (May 1969)

4. Preparation and properties of $\mathrm{ZrO}_{2}$ refractories stabilized by $\mathrm{CeO}_{2}$ A. B. Andreeva, A. I. Leonov and E. K. Keler

Ogneupory 34 [3], 37-44 (March 1969)

5. Phase composition of reduced and reoxidized barium titanate

H. Arend (Inst. Phys., Czech. Acad. Sci., Prague) and L. Kihlborg (Inst. Inorg. \& Phys. Chem., Univ. Stockholm, Sweden)

J. Am. Ceram. Soc. $\underline{52}$ [2], 63-65 (1969)

6. Physico-chemical properties of the binary $\mathrm{ZrO}_{z}-\mathrm{CeO}_{z}$ solid electrolytes M. Asquiedge and 7 others (Electr. de France, Dir. Etudes et Rech., 92-Clamart, Fr.)

Rev. Int. Hautes Temp. Réfract. 6 [1], 35-44 (1969)

7. Resistivity-temperature dependence of high purity $\left(\mathrm{ZrO}_{2}\right)_{0.0}\left(\mathrm{Y}_{2} \mathrm{O}_{3}\right)_{0.1}$

J. E. Bauerle and J. Hrizo (Westinghouse Res. Labs., Pittsburgh, Pa. 15235)

J. Phys. Chem. Solids $\underline{30}$ [3], 565-70 (1969)

8. Cation self-diffusion in polycrystalline $\mathrm{Y}_{2} \mathrm{O}_{3}$ and $\mathrm{Er}_{2} \mathrm{O}_{3}$

M. F. Berard and D. R. Wilder (Inst. Atom. Res. \& Ceram. Eng. Dept.,

Iowa State Univ., Ames, Iowa 50010)

J. Am. Ceram. Soc. 52 [2], 85-88 (1969) 
Eb. 9. Behavior of metal oxides injected into an argon induction plasma

C. Borgianni, M. Capite111, F. Cramarossa, I. Triolo and E. Molinari

Combust. Flame 13 [2], 181-94 (1969)

10. Creep and vaporizability of basic refractories

L. B. Borovkova, E. S. Lukin, E. Ya. Shapiro and D. N. Poluboyarinov Ogneupory 34 [1], 37-43 (Jan. 1969)

11. Electrical conduction in Li-doped CoO

A. J. Bosman and C. Crevecoeur (Philips Res. Labs., Eindhoven, Netherlands)

J. Phys. Chem. Solids 30, 1151-60 (1969)

12. Defect structure of $\mathrm{Y}_{2} \mathrm{O}_{3}-\mathrm{ZrO}_{2}$ solid solutions

R. J. Bratton (Westinghouse Electric Co. R/D Ctr., Pittsburgh, Pa. 15235)

J. Am. Ceram. Soc. $\underline{52}[4], 213$ (1969)

13. Modulus of rupture as an index of potential refractory performance in service

D. S. Buist, A. Highfleld and H. Pressley (Gen. Refract. Res. Labs., Worksop, U. K.)

Trans. Brit. Ceram. Soc. 68, 45-51 (1969)

14. Effect of plastic instability on compressive deformation

D. R. Cropper and J. A. Pask (Inorg. Mater. Res. Div., Lawrence Rad. Lab. \& Mater. Sc1. and Eng. Dept., Univ. California, Berkeley, Calif.)

Am. Ceram. Soc. Bu11. $4 \underline{8}[5], 555-58$ (1969)

15. Cathodic luminescence of earth alkaline oxide layers

H. Düsterhöft and R. Köhler (Phys. Inst. 1, Humboldt Univ., Berlin)

Z. Phys. Chem. (Leipzig) 239, 173-84 (1968)

16. Measurement of the viscosity of aluminum oxide

V. P. Elyutin, V. I. Kostikov, B. S. Mitin and Yu. A. Nagibin

(Steel \& Alloys Inst., Moscow)

Zh. F1z. Khim. 43 [3], 579-83 (1969)

17. Thermodynamics of $\mathrm{Fe}_{1-x} \mathrm{O}$ in the single phase region

B. E. F. Fender and F. D. Riley (Inorg. Chem. Lab., Oxford Univ., Oxford, U. K.)

J. Phys. Chem. Solids 30, 793-98 (1969)

18. Computation of the equilibrium vapor composition over $\mathrm{UO}_{2+x}$ M. H. Fontana and R. E. Balley

Nucl. Sc1. Eng. 36 [3], 268-74 (1969) 
Eb. 19. Effect of the phase transformation on the stabilizing reaction of zirconia

O. Fukunaga and S. Saito (Res. Lab. Eng. Mater., Tokyo Inst. Tech., Tokyo)

Yogyo Kyokai Shi 76 $[879], 369-73$ (1968)

20. Reactive hot-pressing of alumina with additives

G. E. Gazza, J. R. Barfield and D. I. Preas (Army Mater. Mech.

Res. Ctr., Watertown, Mass.)

Am. Ceram. Soc. Bull. 48 [6], 606-10 (1969)

21. Formation and diffusion of point defects in $\mathrm{CaTiO}_{3}$

W. L. George (Purdue Univ., 1968)

Dissertation Abstr. 29B [8], 2910 (1968-69)

22. Hot pressing of $\mathrm{B}_{4} \mathrm{C}$

H. Hashimoto and Y. Toibana

Bu11. Govt. Ind. Res. Inst. Osaka 20 [1], 1-10 (1969)

23. High-temperature hemispherical spectral emittance of uranium oxides at 0.65 and $0.70 \mu \mathrm{m}$

P. C. Held and D. R. Wilder (Inst. Atom. Res. \& Ceram. Eng. Dept., Iowa State Univ., Ames, Iowa 50010)

J. Am. Ceram. Soc. 52 [4], 182-86 (1969)

24. Fine-grained magnesite-chrome refractories

R. H. Herron and W. J. Smothers (Bethlehem Steel Co., Homer Res. Labs., Bethlehem, $\mathrm{Pa}$. )

Am. Ceram. Soc. Bull. 48 [5], 544-48 (1969)

25. Why rapid firing is possible

W. H. Holmes (Brit. Ceram. Res. Assoc., Penkhu11, Stoke-on-Trent, U. K.)

J. Brit. Ceram. Soc. 6, 19-22 (1969)

26. Some properties of lime refractories

D. H. Hubble (U. S. Steel Appl. Res. Lab., Monroeville, Pa.)

Am. Ceram. Soc. Bull, 48 [6], 618-21 (1969)

27. Defect diffusion in single crystal $\mathrm{Al}_{2} \mathrm{O}_{3}$

T. P. Jones, R. L. Coble and C. J. Mogab (Ceram. Div., Met. Lept., Mass. Inst. Tech., Cambridge, Mass. 02139)

J. Am. Ceram. Soc. 52 [6], 331-34 (1969)

28. Effects of dopants on sintering of $\mathrm{ZnO}$ and $\mathrm{NiO}$

W. Komatsu, M. Miyamoto, S. Hujita and Y. Moriyoshi (Fac. Eng.,

Tokyo Inst. Tech., Tokyo)

Yogyo Kyokai Shi $\underline{76}$ [880], 407-12 (1968)

29. Thermal stabilization of the $\beta$-form of calcium orthosilicate

V. I. Korneev, M. M. Sychev and L. B. Baigalina

Izv. Akad. Nauk SSSR, Neorg. Mater. 5 [3], 560-64 (1969) 
Eb. 30. Grain boundaries and the phenomena of diffusion in oxides

G. C. Kuczynski (Univ. of Notre Dame, Indiana)

Bu11. Soc. Franc. Céram. [80], 45 (1968)

31. Criterla for the thermal breakdown resistance of heterogeneous refractory materials

G. V. Kukolev, I. I. Nemets and G. B. Dobrovolskii

Ogneupory 34 [2], 41-45 (Feb. 1969)

32. Oxidative capacity of Feo melts and their thermodynamic stability I. S. Kulikov

Izv. Akad. Nauk SSSR, Metal. [2], 50-52 (Mar.-Apr. 1969)

33. Time and length corrections in the analysis of the initial stages of diffusion-controlled sintering

K. W. Lay and R. E. Carter (G. E. R/D Ctr., Schenectady, N. Y. 12301)

J. Am. Ceram. Soc. $\underline{52}[4], 189-91$ (1969)

34. Thermoelectric emission of $\mathrm{ZrO}_{2}$ in the presence of $\mathrm{O}_{3}$

J. P. Loup and A. M. Anthony (Ctr. Rech. Phys. Hautes Temp., 45-Orléans-La Source, Loiret, Fr.)

C. R. Acad. Sc1. 268C, 772 (1969)

35. Annealing of irradiation-induced thermal conductivity changes in $\mathrm{ThO}_{2}-1.3 \mathrm{wt} \% \mathrm{UO}_{2}$

J. R. MacEwan and R. L. Stoute (Fuel Mater. Br., At. Energ. of Canada, Chalk River, Ont., Can.)

J. Am. Ceram. Soc. 52 [3], 160-65 (1969)

36. Effect of heat treatment on the behavior of borided pyro-carbon

S. Marinkovic (Boris Kidrick Inst. Nucl. Sc1., Belgrade, Yugoslavia)

J. Chim. Phys., Special Issue, 84 (April 1969)

37. On the thermal decomposition rate of $\mathrm{Mo}_{2} \mathrm{~S}_{3}$ in vacuum

Y. Maru, H. Yoshida and Y. Kondô (Met. Dept., Univ. of Kyoto, Japan) Trans. Japan Inst. Metals 10 [1], 8-11 (1969)

38. Thermionic emission properties of graphites

Yu. M. Morozov, B. S. Kulvarskaya and Kh. S. Kan

Izv. Akad. Nauk SSSR, Ser. Fiz. 33 [3], 435-38 (1969)

39. Electronic properties of carbons during carbonization and graphitization

S. Mrozowski (State Univ. of N. Y. at Buffalo)

J. ChIm. Phys. [Special No.], 13 (April 1969)

40. Effects of structure on the thermal stability of chamote refractories I. I. Nemets, G. B. Dobrovolski1, G. A. Gogotsi and V. M. Antoninko Ogneupory 34 [4], 56-59 (Apri1 1969) 
Eb. 41. Stress/strain behaviour of refractorles at high temperatures G. C. Padgett, J. A. Cox and J. F. Clements (Brit. Ceram. Res. Assoc., Penkhull, Stoke-on-Trent, U. K.)

Trans. Brit. Ceram. Soc. 68, 63-72 (1969)

42. The influence of $\mathrm{Al}_{2} \mathrm{O}_{3}$ on the stabilization of $\mathrm{ZrO}_{2}$ by $\mathrm{Y}_{2} \mathrm{O}_{3}$ S. F. Palguev, V. N. Strekalovskil and D. S. Stefanovich (Acad. Sc1., Electrochem. Inst., Sverdlovsk, USSR) Dokl. Akad. Nauk SSSR 184 [6], 1376-79 (1969)

43. Dissociation of chalcogenides of the $\mathrm{Zn}$ subgroup in the gaseous phase

A. S. Pashinkin and B. A. Salamatin

Izv. Akad. Nauk SSSR, Neorg. Mater. $\underline{5}$ [2], 256-59 (1969)

44. Sintering and hot-pressing of non-oxide refractorles, borides, carbides, nitrides and silicides

H. Pastor (Lab. Ctr. Ugine Carbone, Grenoble, Fr.)

Ind. Céram. [615], 89 (1969)

45. The rmal dissociation of alkaline-earth metal oxides and its role in mechanism of hot oxide-coated cathode activation

G. Ya. Pikus and V. F. Shnyukov (State Univ., Kiev, USSR)

Izv. Akad. Nauk SSSR, Ser. F1z. 33 [3], 397-402 (1969)

46. Influence of an electric fleld on vaporization of oxygen from alkaline earth oxides

G. Ya. Pikus and V. P. Teterya (State Univ., Klev, USSR)

Izv. Akad. Nauk SSSR, Ser. Fiz. 33 [3], 403-08 (1969)

47. On the existence and stability of $\mathrm{AB}_{2} \mathrm{O}_{4}$ compounds formed by the alkaline earth and lanthanide oxides

F. Queyroux (Ctr. Etudes Chim. Mét., 94-Vitry/Seine, Val de Marne, Fr.)

C. R. Acad. Sc1. 268C, 403 (1969)

48. Preparation, properties and electronic structure of refractory carbides and related compounds

L. Ramquist (Inst. Ind. Res., Nynäshamn, Sweden)

Jernkontorets Annaler 153 [4], 159 (1969)

49. Radiation coefficient of refractory compounds

G. V. Samsonov, I. A. Podchernyaeva and V. S. Fomenko

Porosh. Met. $\underline{9}$ [5], 43-50 (May 1969)

50. Study of a hard carbon (Coke de Saccharose). Effects of heat treatment

C. Schiller, J. Méring and M. Oberlin (Equipe Rech. C.N.R.S. No.3, E.S.P.C.I., Paris)

J. App1. Cryst. 1, 282 (1969) 
Eb. 51. Hot extrusion of strontium zirconate

V. S. Shakhin, N. I. Bogdanov and V. L. Balkevich

Ogneupory 34 [5], 41-45 (May 1969)

52. Magnetic investigations on arsenides of transition elements

R. Sobczak, H. Boller and H. Bittner (Inst. Phys. Chem., Univ. Wien, Austria)

Monatsh. Chem. 99, 2227-34 (1968)

53. Kinetics of precipitation and measurements of strain in the system $\mathrm{MgO}-\mathrm{Al}_{2} \mathrm{O}_{3}-\mathrm{Cr}_{2} \mathrm{O}_{3}$

V. S. Stubican, C. Greskovich and H. A. McKinstry (Mater. Sci. Dept. \& Mater. Res. Lab., Pennsylvania State Univ., Univ. Park, $\mathrm{Pa}$. 16802)

J. Am. Ceram. Soc. 52 [4], 174-77 (1969)

54. Role of electrons in the refractoriness of metal oxides

J. P. Suchet (CNRS Lab. Magnét. et Phys. Solide, 92-Bellevue-Meudon, Fr.)

C. R. Acad. Sci. 268C, 891 (1969)

55. Compressive creep of high purity $\mathrm{Al}_{2} \mathrm{O}_{3}$ refractories

L. J. Trostel, Jr. (R/D Dept., Refract. Div., Norton Co., Worcester, Mass.)

Am. Ceram. Soc. Bull. 48 [6], 601-05 (1969)

56. Enthalpy and heat capacity of $\mathrm{Gd}_{2} \mathrm{O}_{3}$ at high temperatures

D. Sh. Tsagareishvili, G. G. Gvelesiani and T. S. Yashvili (Acad. Sci., Met. Inst., Tbilisi, GessR)

Zh. Fiz. Khim. $\underline{43}$ [4], 882-85 (1969)

57. Volume change on freezing of $\mathrm{Al}_{2} \mathrm{O}_{2}$

P. Tyrolerova and W.-K. Lu (Met. \& Mater. Sci. Dept., McMaster Univ., Hamilton, Ont., Can.)

J. Am. Ceram. Soc. $\underline{52}[2], 77-79$ (1969)

58. Volume change of mullite on solidification

P. Tyrolerova and W.-K. Lu (Met. \& Mater. Sci. Dept., McMaster Univ., Hamilton, Ont., Can.)

J. Am. Ceram. Soc. $\underline{52}[5], 292$ (1969)

59. Compressive creep characteristics of selected refractories

J. F. Wosinski, G. C. Shay and W. H. Edmister (Corning Glass Works, Corning, N. Y.)

Am. Ceram. Soc. Bull. 48 [5], 540-43 (1969)

60. Siliconated pyrolytic graphite

S. Yajima and T. Hirai (Res. Inst. Metals, Tohoku Univ., Sendai, Japan)

J. Mater. Sc1. 4, 416-31 (1969) 
Eb. 61. Alumina coatings made with the plasma gun. I. Effect of some variables on the production and properties of the coatings. II. Effect of heat treatment of the coatings on their properties P. Zoltowski (Phys. Chem. Inst., Polish Acad. Sci., Warsaw 42) Rev. Int. Hautes Temp. Réfract. 5, 253 (1968) and $\underline{6}$ [1], 65-70 (1969)

c. Mixed materials

1. An investigation of the yield strength of a dispersion-hardened $\mathrm{W}-3.8$ vol pct $\mathrm{ThO}_{2}$ alloy

G. W. King (Westinghouse Electric, Lamp Div., Bloomfield, N. J.)

Trans. Met. Soc. AIME 245 [1], 83-89 (1969)

2. Thermal properties of $\mathrm{Al}_{2} \mathrm{O}_{3}$-base metal ceramics in temperature range $473-1673^{\circ} \mathrm{K}$

V. A. Osipova and M. I. Pak

At. Energ. (USSR) 26 [1], 72 (1969)

3. Thermal emission of alloys of tungsten with the lanthanide oxides

G. V. Samsonov, I. A. Podcher-Yaeva, V. S. Fomenko and I. Ya. Kondratov (Inst. Problems Mater. Sci., Acad. Sci., Kiev, USSR)

Rev. Int. Hautes Temp. Réfract. $\underline{5}, 223$ (1968)

4. Effect of $\mathrm{ThO}_{2}$ particles on grain growth and preferred orientation in $W$ sheet

J. L. Walter and A. U. Seybolt (G. E. R/D Ctr., Schenectady, N. Y.) Trans. Met. Soc. AIME 245 [5], 1093-99 (1969)

F. Properties, at temperatures above $1000{ }^{\circ} \mathrm{C}$, of materials which melt below $1500^{\circ} \mathrm{C}$

a. Metallic materials

1. The vapor pressure of liquid U; effects of dissolved Ta, P, S, C and 0

R. J. Acknermann and E. G. Rauh (Argonne Nat. Lab., Argonne, I11. 60439)

J. Phys. Chem. $\underline{73}[4], 769-78$ (1969)

2. Experimental determination of the saturated vapor pressure of Li

V. M. Anisimov and L. D. Volyak

Teplofiz. Vys. Temp. [ [2], 371-72 (1969)

3. Viscosity of $\mathbf{F e}-\mathbb{N}$ system melts

P. P. Arsentev, S. I. Filippov and B. S. Lisitskii

Izv. Vyssh. Ucheb. Zaved., Chern. Met. 11 [12], 111-13 (Dec. 1968)

4. Sulfur in liquid iron alloys. II. Effects of alloying elements

S. Ban-ya and J. Chipman (Met. Dept., Mass. Inst. Tech., Cambridge, Mass.)

Trans. Met. Soc. AIME 245 [1], 133-43 (1969) 
Fa. 5. S in liquid Fe alloys. III. Multi-component systems

S. Ban-ya and J. Chipman (Met. \& Mater. Sci. Dept., Mass. Inst. Tech., Cambridge, Mass.)

Trans. Met. Soc. AIME 245 [2], 391-96 (1969)

6. Activity of $\mathrm{C}$ in $\mathrm{Fe}-\mathrm{C}$ alloys at $1150{ }^{\circ} \mathrm{C}$

S. Ban-ya, J.F. Elliott and J. Chipman (Dept. Met. \& Mater. Sci., Mass. Inst. Tech., Cambridge, Mass.)

Trans. Met. Soc. AIME 245 [6], 1199-1206 (1969)

7. Activities in the liquid Fe-Cr-O system

R. J. Fruehan (U. S. Steel Lab. Fundmt1. Res., Monroeville, Pa.)

Trans. Met. Soc. AIME 245 [6], 1215-18 (1969)

8. Diffusion of $\mathrm{Zn}$ and $\mathrm{Ge}$ in liquid $\mathrm{Ag}$

Y. P. Gupta and H. S. Wang (School of Miner. \& Met. Eng., Univ. of Minnesota, Minneapolis, Minn.)

Trans. Met. Soc. AIME 245 [4], 619-22 (1969)

9. Electromotive force studies of liquid $U-Z n$ alloys

Y. Hoshino and J. A. Plambeck (Tokyo Inst. Tech., Chem. Dept., Meguro, Tokyo)

Can. J. Chem. 47 [6], 965-70 (1969)

10. Effect of Ca-Si additions on the dissolved $\mathrm{O}_{2}$ content of liquid stee 1

R. K. Iyengar and G. C. Duderstadt (Jones \& Laughlin Steel Co., Graham Lab.)

Trans. Met. Soc. AIME 245 [4], 807-13 (1969)

11. Density of molten lead between 330 and $1550{ }^{\circ} \mathrm{C}$

L. D. Lucas (IRSID, 78-St. Germain en Laye, Yvelines, Fr.)

C. R. Acad. Sci. 268C, 1081 (1969)

12. Very-short-time, very-high-temperature creep rupture of type 347 stainless steel and correlation of data

C. D. Lundin, A. H. Aronson, L. A. Jackman and W. R. Clough

J. Basic Eng. 91D [1], 32-36 (1969)

13. Thermodynamics of nitrogen solutions in Fe-Cr, Fe-Mn and Fe-Cr-Mn melts

V. P. Memtsenko, I. P. Malkin and S. I. Popel

Izv. Vyssh. Ucheb. Zaved., Chern. Met. 11 [12], 5-8 (Dec. 1968)

14. Mass spectrometric determination of thermodynamic activities. $\mathrm{Au}-\mathrm{Cu}$ system

A. Neckel and S. Wagner (Inst. Phys. Chem., Univ. Wien, Austria)

Ber. Bunsenges. Phys. Chem. 73 [2], 210-17 (1969)

15. Solubility of $\mathbb{N}_{2}$ in molten Fe-Cr-Mn-Si-C alloys, and its influence on the properties of steel

P. E. Nizhelskii and S. G. Ryskina

Izy. Vyssh. Ucheb. Zaved., Chern. Met, 11 [12], 47-50 (Dec. 1968) 
Fa. 16. Evaporative losses during vacuum induction melting of Ni-base alloys N. D. Obradovic and G. H. J. Bennett (Ind. Met. Dept., Univ, of Birmingham, U. K.)

J. Inst. Metals 97, 186-90 (1969)

17. Experimental study of the enthalpies of molten $\mathrm{Rb}$ and $\mathrm{Cs}$ at 400 to $1350^{\circ} \mathrm{K}$

E. E. Shpilrain and D. N. Kagan

Teplofiz. Vys. Temp. 7 [2], 362-63 (1969)

18. Radiative heat loss from the surface of molten steel held in a ladle

J. Szekely and J. W. Evans (Chem. Eng. Dept., State Univ. New York at Buffalo, N. Y.)

Trans. Met. Soc. AIME 245 [6], 1149-59 (1969)

19. Solubility of $\mathrm{N}_{2}$ in molten $\mathrm{Fe}-\mathrm{NI}$ and $\mathrm{Fe}-\mathrm{Cr}$ alloys

H. Wada, K. Gunji and T. Wada (Nat. Res. Inst. Met., Meguro-ku, Tokyo)

Nippon Kinzoku Gakka1 Shi $\underline{32}$ [10], 933-38 (1968)

20. Solubility of $\mathrm{N}_{z}$ and its interaction with $\mathrm{O}_{z}$ in liquid $\mathrm{Fe}$ H. Wada, K. Gunji and T. Wada (Nat. Res. Inst. Met., Meguro-ku, Tokyo)

Nippon Kinzoku Gakkai Shi 32 [9], 831-36 (1968)

21. Solubility of nitrogen in arc-melted and levitation-melted Fe and Fe alloys

T. Wada and M. Uta (Nat. Res. Inst. Met., Meguro-ku, Tokyo)

Rept. Nat. Res. Inst. Met. 11 [6], 55-67 (1968)

22. Microstructure and tensile properties of $\mathrm{Ni-rich} \mathrm{Ni}-\mathrm{Si}$ and $\mathrm{Ni-Si-Ti}$ alloys

K. J. Williams (Int. Nickel Co. Res. Dept., Birmingham, U. K.)

J. Inst. Metals 97, 112-18 (1969)

23. Bolling of molten alkali metals in tubes

Yu. A. Zeigarnik and V. D. Litvinov

Teplofiz. Vys. Temp. I [2], 374-76 (1969)

24. Thermal diffusivity and heat conductivity of iron at high temperatures V. E. Zinovev, R. P. Krentsis and P. V. Geld Fiz. Metal. Metallov. 26 [4], 743-44 (1968)

b. Non-metallic materials

1. Transparent glass ceramics

G. H. Beall and D. A. Duke (Res. Labs., Corning Glass Works, Corning, N. Y.)

J. Mater.Sci. 4, 340-52 (1969) 
Fb. 2. Measurements of the viscosity of supercooled slags at 750 to $1100^{\circ} \mathrm{C}$ J. Boow

Fuel (London) 48 [2], 171-78 (1969)

3. Different modes of phase separation and crystallization in the alkaline earth aluminosilicate glass-ceramics

J. Bray (Ohaverbel-Gilly, Belgium)

Bul1. Soc. Franc. Ceram. [80], 111 (1968)

4. Effect of As on gas composition in seed during glass refining M. Cable, A. R. Clarke and M. A. Haroon (Glass Tech. Dept., Univ. of Sheffield, U. K.)

Glass Technol. 10, 15-21 (1969)

5. Secondary grain growth of $\mathrm{Li}_{2} \mathrm{O}-\mathrm{Al}_{2} \mathrm{O}_{3}-\mathrm{SiO}_{2}-\mathrm{TiO}_{2}$ glass-ceramics

C. K. Chyung (R/D Labs., Corning Glass Works, Corning, N. Y. 14830)

J.Am. Ceram. Soc. $\underline{52}[5], 242-45$ (1969)

6. Diffusion of "water" in soda-lime glass within and near the transformation range

D. R. Cockram, Z. Haider and G. J. Roberts (Glass Tech. Dept., Univ. of Sheffield, U. K.)

Phys. Chem. Glasses 10, 18-22 (1969)

7. Thermodynamic properties of the ternary oxides $\mathrm{CaO} \cdot \mathrm{FeO}_{0} \mathrm{Fe}_{3} \mathrm{O}_{3}$ and $\mathrm{CaO} .3 \mathrm{FeO} . \mathrm{Fe}_{2} \mathrm{O}_{3}$

M. C. Dufour, P. Perrot and G. Tridot (Fac. Sci. Lille, 59-Annappes, Nord, Fr.)

C. R. Acad. Sci. 268C, 831 (1969)

8. Electrical conductance in the liquid $\mathrm{PbO}-\mathrm{SiO}_{2}$ binary system

T. Ejima, Y. Watanabe and M. Kameda (Met. Dept., Fac. Eng., Tohoku Univ., Sendai, Japan)

Nippon Kinzoku Gakkai Shi $\underline{32}$ [12], 1250-56 (1968)

9. Electrical conductance in the 1iquid $\mathrm{PbO}-\mathrm{SiO}_{z}-\mathrm{Mo}$ ternary system T. Ejima, Y. Watanabe and M. Kameda (Met. Dept., Fac. Eng., Tohoku Univ., Sendai, Japan)

Nippon Kinzoku Gakkai Shi 32 [12], 1256-62 (1968)

10. Conductivity of molten $\mathrm{Li}_{2} \mathrm{O}-\mathrm{RO}-\mathrm{B}_{2} \mathrm{O}_{3}$ and $\mathrm{K}_{2} \mathrm{O}-\mathrm{RO}-\mathrm{B}_{2} \mathrm{O}_{3}$ glasses

E. A. Erznkyan and K. A. Kostanyan (Chem. Sci. Res. Inst., Yerevan, ArSSR)

Arm. Khim.Zh. 22 [2], 103-10 (1969)

11. Electrical conductivity of $\mathrm{Li}_{2} \mathrm{O}-\mathrm{MO}-\mathrm{SiO}_{2}$ glasses in the molten state E. A. Erznkyan and K. A. Kostanyan

Arm. Khim. Zh. 21 [9], 759-66 (1968)

12. Physico-chemical study of lead telluride

A. M. Gaskov, 0. V. Matveev, V. P. Zlomanov and A. V. Novosiolova

(State Univ., Inorg. Chem. Dept., Moscow)

Vest. Mosk. Univ., Khim. [2], 115 (Mar.-Apr. 1969) 
Fb. 13. Behavior of bubbles of $\mathrm{O}_{2}$ and $\mathrm{SO}_{2}$ in soda-lime glass

C. H. Greene and D. R. Platts (Glass Sci. Dept., State Univ. of New York, College of Ceramics at Alfred Univ., Alfred, N. Y. 14802) J. Am. Ceram. Soc. 52 [2], 106-09 (1969)

14. Surface tension, density and viscosity of $\mathrm{PbO}-\mathrm{Na}_{2} \mathrm{O}-\mathrm{SiO}_{2}$ ternary melt M. Hino, T. Ejima and M. Kameda (Met. Dept., Fac. Eng., Tohoku Univ., Sendai, Japan)

Nippon Kinzoku Gakkai Shi $\underline{32}$ [9], 810-14 (1968)

15. Dissolution of silica particles in molten sodium disilicate J. Hlavac and H. Nademlynska (Inst. of Chem. Tech., Prague) Glass Technol. 10, 54-58 (1969)

16. Determination of the viscosity of glasses by chemical composition L. V. Isaeva

Izv. Akad. Nauk SSSR, Neorg. Mater. $\underline{5}$ [2], 331-34 (1969)

17. Change in the optical characteristics of molten open hearth slags E. A. Kairov, V. A. Krivandin and B. S. Mastryukov

Izv. Vyssh. Ucheb. Zaved., Chern. Met. 12 [1], 159-63 (Jan. 1969)

18. Dissociation of copper oxides

E. K. Kazenas, D. M. Chizhikov and Yu. V. Tsvetkov

Izv. Akad. Nauk SSSR, Meta1. [2], 60-62 (Mar.-Apr. 1969)

19. Effect of slag viscosity on the elimination of non-metallic

inclusions during electro slag remelting

V. V. Khlynov, G. A. Vatsgov and O. A. Esin

Izv. Vyssh. Ucheb. Zaved., Chern. Met. 11 [12], 9-13 (Dec. 1968)

20. The activity of iron oxide in FeO-MgO-S1O 2 slags at $1600{ }^{\circ} \mathrm{C}$ Y. Kojima, M. Inouye and K. Sano Arch. Eisenhüt tenw. 40, 37-40 (1969)

21. Sulfide capacities of basic slags containing $\mathrm{CaF}_{2}$ G. J. W. Kor and F. D. Richards on (Met. Dept., Imperial College, London)

Trans. Met. Soc. AIME 245 [2], 319-27 (1969)

22. Measurement of the dissociation pressure of potassium carbonate in the temperature range from 900 to $1500{ }^{\circ} \mathrm{K}$ T. Kosugi (Hitachi Res. Lab., Hitachi, Japan) Kogyo Kagaku Zasshi 71 [10], 1581-86 (1968)

23. Thermal properties of $A^{3} B^{5}$ compounds. II. High-temperature heat contents and heats of fusion of InAs and GaAs

B. D. Lichter and P. Sommelet (Inorg. Mater. Res. Div., Lawrence Rad. Lab. and Miner. Tech. Dept., Univ. of Californla, Berkeley) Trans. Met. Soc. AIME 245 [5], 1021-27 (1969) 
Fb. 24. Thermal properties of $A^{3} B^{5}$ compounds. I. High-temperature heat contents and heats of fusion of InSb, GaSb and AlSb

B. D. Lichter and P. Sommelet (Inorg. Mater. Res. Div., Lawrence Rad. Lab. and Dept. of Miner. Tech., Univ. of California, Berkeley)

Trans. Met. Soc. AIME 245 [1], 99-105 (1969)

25. Thermodynamic study of $\mathrm{SiO}_{2}-\mathrm{FeO}-\mathrm{MnO}$ slags

N. Meysson and A. Rist (IRSID, Maizières les Metz, Fr。)

Rev. Met. 66, 115 (1969)

26. Density of iron oxide melts in equilibrium with $\mathrm{CO}_{2}-\mathrm{CO}$ gas mixtures

K. Mori and K. Suzuki (Iron Steel Eng. Dept., Fac. Eng., Univ. of Nagoya, Japan)

Tetsu To Hagane 54 [11], 1123-27 (1968)

27. Structural change during the process of formation of a transparent glass ceramic

Y. Moriya (Govt. Ind. Res. Inst., Osaka, Ikeda, Japan)

Yogyo Kyokai Shi 76 [877], 293-305 (1968)

28. Structure and properties of glasses and glass-forming melts. II. Electrical conductivity of molten alkali borates and phosphates structure model and interpretation

K. -P. Müller

Glastech. Ber $\underline{42}$, 44-51 (1969)

29. Kinetics and mechanism of crystalization of lithlum silicate glasses

T. Ogura, R. Hayami and M. Kadota (Govt. Ind. Res. Inst., Osaka, Ikeda, Japan)

Yogyo Kyokai Shi $\underline{76}[876], 277-84$ (1968)

30. Effect of $O_{2}$ partial pressure on non-stoichiometry and electrical conductivity of $\mathrm{V}_{2} \mathrm{O}_{5}-\mathrm{Cu}_{2} \mathrm{O}$ melts

E. A. Pastukhov, O. A. Esin and N. A. Vatolin (Met. Inst., Sverdlovsk, USSR)

Zh. Fiz. Khim. 43 [3], 584-87 (1969)

31. Measurement of surface tension of glasses by a capillary flow technique

D. R. Secrist (IBM Systems Devel. Div., San Jose, Calif.)

Am. Ceram. Soc. Bu11. 48 [5], 563-69 (1969)

32. Saturated vapor pressure in the $\mathrm{PbTe}-\mathrm{PbSe}$ system

V. V. Sokolov, V. A. Dolgikh, A. S. Pashinkin and A. V. Novoselova (Chem. Fac., Moscow State Univ.)

Izv. Akad. Nauk SSSR, Neorg. Mater. $\underline{5}$ [2], 279-82 (1969)

33. Saturated vapor pressure in the PbTe-SnTe system

V. V. Sokolov, A. A. Ryazantsev, A. S. Pashinkin and A. V. Novoselova (Chem. Fac., Moscow State Univ.)

Izv. Akad. Nauk SSSR, Neorg. Mater. $\underline{5}$ [2], 275-78 (1969) 
$\mathrm{Fb}$. 34. Thermodynamics of $\mathrm{PbO}-\mathrm{B}_{2} \mathrm{O}_{3}$ and $\mathrm{PbO}-\mathrm{P}_{2} \mathrm{O}_{5}$ melts

R. Sridhar and J. H. E. Jeffes (Met. Dept., Imperial College, Lond on S.W.7)

Trans. Inst. Mining Met. $\underline{78 C}, 14-20$ (1969)

35. Flow of glass in electric furnaces

J. Stanek, L. Sasek and H. Meissnerova (Silicate Tech. Dept., Inst. of Chem. Tech., Prague)

Glass Technol. 10, 43-49 (1969)

36. Solubility of $\mathrm{H}_{2}$ in slags of the system $\mathrm{CaO}-" \mathrm{FeO} "-\mathrm{SiO}_{z}$

M. Wahlster and H.-H. Reichel

Arch. Eisenhüttenw. 40, 19-25 (1969)

37. Free energy of solution in binary silicate melts

T. Yokokawa and K. Niwa (Hokkaido Univ., Fac. Sci., Dept. Chem., Sapporo, Japan)

Trans. Japan Inst. Metals $\underline{10}$ [1], 3-7 (1969)

c. Mixed materials

1. Diffusion layers between carbon steel and cemented carbides containing $\mathrm{TaC}$ or $\mathrm{TiC}$

H. Suzuki, T. Yamamoto and I. Kawakatsu (Met. Dept., Fac. Eng., Univ. of Tokyo)

Nippon Kinzoku Gakkai Shi $\underline{32}$ [8], 721-25 (1968)

G. Phase equilibria above $1000^{\circ} \mathrm{C}$

1. The silver-calcium phase diagram

W. A. Alexander, L. D. Calvert, A. Desaulniers, H. S. Dunsmore and D. F. Sargent (Nat. Res. Council, Appl. Chem. Div., Ottawa, Ont., Canada)

Can. J. Chem. 47 [4], 611-14 (1969)

2. Phase relations in the system $\mathrm{Li}_{2} \mathrm{O}-\mathrm{Na}_{2} \mathrm{O}-\mathrm{Al}_{2} \mathrm{O}_{3}-\mathrm{SiO}$ with special emphasis on the silica polymorphs

W. B. Badger (Pennsylvania State Univ., 1968)

Dissertation Abstr. 29B [10], 3695 (1968-69)

3. Phase equilibria in the CaO-MnZn ferrite system

Y. Bando, T. Kato, Y. Ikeda and T. Takada

Bull. Inst. Chem. Res., Kyoto Univ. 46 [6], 289-94 (1968)

4. Melting point studies of the system UP-US

Y. Baskin and P. D. Shalek

J. Am. Ceram. Soc. $\underline{52}[6], 341-42$ (1969)

5. Phase diagram of the binary system $\mathrm{SrO}_{-}-\mathrm{Ga}_{2} \mathrm{O}_{3}$

P. Batti and G. Sloccari (Univ. Trieste, Inst. Chim. Appl., Trieste, Italy)

Ann. Chim. (Rome) 59 [2], 155-62 (1969) 
G. 6. Physical and chemical investigation of CdSb-Ge section of the ternary system $\mathrm{Cd}-\mathrm{Sb}-\mathrm{Ge}$

D. P. Belotsky and M. P. Kotsyumakha (State Univ., Chernovtsy, UkSSR)

Dopovidi Akad. Nauk Ukr. RSR, Ser. A-Fiz. Tekh. Mat. Nauk [3], 244-46 (1969)

7. Investigation of the $\mathrm{PbTe}-\mathrm{Tl}_{2} \mathrm{Te}$ system

L. G. Berg, Z. M. Latypov and R. M. Chechetkin (Lenin State Univ., Kazan, USSR)

Dok1. Akad. Nauk SSSR $\underline{185}$ [2], 335-37 (1968)

8. The $\mathrm{Na}_{2} \mathrm{SO}_{4}-\mathrm{Na}_{2} \mathrm{~B}_{4} \mathrm{O}_{4}-\mathrm{Na}_{4} \mathrm{P}_{2} \mathrm{O}_{7}$ system

A. G. Bergman, A. M. Gasanaliev and A. S. Trunin (Const. Eng. Inst., Rostov-on-Don, USSR)

Zh. Neorg. Khim. 14 [5], 1422-23 (1969)

9. The system $\mathrm{CaO}-\mathrm{NiO}-\mathrm{SiO}_{2}$

G. M. Biggar (Geol. Dept., Edinburgh Univ., Edinburgh, Scotland)

J. Am. Ceram. Soc. 52 [6], 316-17 (1969)

10. Monticellite and forsterite crystalline solutions

G. M. Biggar and M. J. O'Hara (Grant Inst. Geol., Univ. of Edinburgh, Scotland)

J. Am. Ceram. Soc. 52 [5], 249-52 (1969)

11. Temperature control and calibration in quench furnaces and some measurements in the system $\mathrm{CaO}-\mathrm{MgO}-\mathrm{Al}_{2} \mathrm{O}_{3}-\mathrm{SiO}_{2}$

G. M. Biggar and M. J. O'Hara (Grant Inst. Geol., Univ. of Edinburgh, Scotland)

Minera1. Mag. 37, 1-15 (1969)

12. High pressure phase of $\mathrm{Al}_{2} \mathrm{GeO}_{5}$

J. D. Birle and E. G. Ehlers (Ohio State Univ., Columbus, Ohio 43210)

J. Am. Ceram. Soc. $\underline{52}[5], 287-88$ (1969)

13. Cut of the $\mathrm{U}-\mathrm{O}-\mathrm{N}$ diagram by the $\mathrm{UO}_{2}-\mathrm{U}_{2} \mathrm{~N}_{3}$ plane

P. L. Blum, J. Laugier and J. M. Martin (C.E.N., 38-Grenoble, Isère, Fr.)

C. R. Acad. Sci. 268C, 148 (1969)

14. An induced phase transformation in $\mathrm{BaTiO}_{3}$ single crystals

V. Z. Borodin and V. G. Kuznetsov

Izv. Akad. Nauk SSSR, Fiz. 33 [2], 308-12 (1969)

15. Investigation of the $\mathrm{Zr}-\mathrm{Co}-\mathrm{Al}$ system

V. V. Burnashova and V. Ya. Markiv (State Univ., Lvov, UkSSR) Dopovidi Akad. Nauk Ukr. RSR, Ser. A-Fiz. Tekh. Mat. Nauk [1], 59-60 (1969) 
G. 16. Ternary phase equilibria of BaNa niobate

J. R. Carruthers and M. Grasso (Bell Tel. Labs., Murray Hill, N. J.)

Mater. Res. Bu11. 4 [7], 413-23 (1969)

17. The system Ta-Zn: phase studies

M. G. Chasanov, R. Schablaske and I. Johnson (Argonne Nat. Lab., Argonne, Ill. 60439)

J. Electrochem. Soc. Japan $\underline{36}$ [4], 192-95 (1968)

18. Study of the Ge-FeS and GeS-FeS sections in the Ge-Fe-S system D. M. Chizhikov, L. V. Nikiforov and Yu. A. Lainer

Izv. Akad. Nauk SSSR, Neorg. Mater. 5 [2], 290-94 (1969)

19. The system $\mathrm{Li}_{3} \mathrm{BN}_{2}$ at high pressures and temperatures

R. C. DeVries and J. F. Fleischer (G. E. R/D Ctr., Schenectady, N. Y. 12301)

Mater. Res. Bul1. 4 [7], 433-41 (1969)

20. The systems $\mathrm{MF}_{2}-\mathrm{CrF}_{2}(\mathrm{M}=\mathrm{Ca}, \mathrm{Sr}, \mathrm{Ba})$

D. Dumora and J. Ravez (Fac. Sci. Bordeaux, 33-Talence, Gironde, Fr.)

C. R. Acad. Sci. 268C, 337 (1969)

21. Occurrence of CsCl-type phases and of related distorted structures in alloys of transition metals

A. E. Dwight and P. A. Beck (Argonne Nat. Lab., Argonne, Ill. and Met. Dept., Univ. of Illinois, Urbana, Il1.)

Trans. Met. Soc. AIME 245 [2], 389-90 (1969)

22. The compounds of the $\mathrm{Cr}_{5} \mathrm{~B}_{3}$ and $\mathrm{Mn}_{5} \mathrm{Si}_{3}$ types in the rare-earth metal-gallium sys tems

D. I. Dzyana and P. I. Krypyakevich (State Univ., Lvov, UkSSR) Dopovidi Akad. Nauk Ukr. RSR, Ser. A-Fiz. Tekh. Mat. Nauk [3], 247-49 (1969)

23. Comparative study of the solubility of $\mathrm{MgO}$ and $\mathrm{Fe}_{2} \mathrm{O}_{3}$ in cubic $\mathrm{ZrO}_{2}$ S. Ferrier, M. Therasse and G. Montel (Fac. Sci., 31-Toulouse, Fr.) C. R. Acad. Sci. 268C, 1043 (1969)

24. Subsolidus relations in the system $2 \mathrm{CaO} \cdot \mathrm{SiO}_{2}-3 \mathrm{CaO} \cdot \mathrm{P}_{2} \mathrm{O}_{5}$

W. Fix, H. Heymann and R. Heinke (Inst. Eisenhüttenw., Tech. Univ. Claus tha 1, Claus thal-Zellerfeld, Germ.)

J. Am. Ceram. Soc. $\underline{52}[6], 346-47$ (1969)

25. The eta carbides of Mo-Fe, Mo-Co and Mo-Ni

A. C. Fraker (Nat. Bur. Standards, Washington, D. C.) and H. H. Stadelmaier (Met. Dept., North Carolina State Univ., Raleigh, N. C.)

Trans. Met. Soc. AIME 245 [4], 847-50 (1969) 
G. 26. The solubility of graphite in Fe-Ni and $\mathrm{Fe}-\mathrm{Co}$ alloys at $1000{ }^{\circ} \mathrm{C}$ D. J. Fray and J. Chipman (Mass. Inst. Tech., Cambridge, Mass.) Trans. Met. Soc. AIME 245 [5], 1143-44 (1969)

27. Phase equilibrium between $\mathrm{MnO}_{2}$ and $\mathrm{Mn}_{2} \mathrm{O}_{3}$

0. Fukunaga, K. Takahashi, T. Fujita and J. Yoshimoto (Nat. Inst. Res. Inorg. Mater., Bunkyo-ku, Tokyo 113)

Mater. Res. Bu11. 4 [5], 315-22 (1969)

28. Solid solutions and polymorphism in the $\mathrm{ZrO}_{2}-\mathrm{HfO}_{2}$ system

A. M. Gavrish, B. J. Sukharevski, P. P. Krivoruchko and E. I. Zoz Izv. Akad. Nauk SSSR, Neorg. Mater. $\underline{5}$ [3], 547-50 (1969)

29. New $A_{3} B_{5}$ phases of the Ti group metals with Rh

B. C. Giessen, R. Wang and N. J. Grant (Dept. Met. \& Mater. Sci.,

Mass. Inst. Tech., Cambridge, Mass.)

Trans. Met. Soc. AIME 245 [6], 1207-10 (1969)

30. The $\mathrm{Zr}-\mathrm{Re}-\mathrm{C}$ ternary system

L. V. Gorshkova, Yu. V. Voroshilov and T. F. Fedorov

Porosh. Met. 9 [2], 82-85 (Feb. 1969)

31. Investigation of the $\mathrm{Ge}-(\mathrm{Au}+0.9 \mathrm{wt} \% \mathrm{As})$ section in the temperature range $600-800{ }^{\circ} \mathrm{C}$

A. Ya. Gubenko and M. B. Miller

Izv. Akad. Nauk SSSR, Neorg. Mater. $\underline{\text { [2] }}$, 235-38 (1969)

32. Studies in the Co-rich corner in the Co-Cr-W-C system

o. Knotek, H. Seifarth and R. Kieffer (Inst. Chem. Tech. Anorg. Stoffe, T. H. Wien, Austria)

Arch. Eisenhïttenw. 39, 869-75 (1968)

33. Determination of the temperature of the phase transformation of BeO Yu. A. Kocherzhinskii, E. A. Shishkin and I. M. Yupko Ogneupory 34 [5], 50 (May 1969)

34. Recrystallization diagrams of alloyed Mo

Ch. V. Kopetskil, M. V. Pridantsev and L. G. Smolyakova

Metallov. Term. Obrab. Meta1. [1], 18-20 (Jan. 1969)

35. Isothermal cross sections of the $\mathrm{Ti}-\mathrm{Zr}-\mathrm{Cr}$ system

I. I. Kornilov, O. K. Belous ov and R. S. Musaev

Izv. Akad. Nauk SSSR, Meta1. [2], 167-69 (Mar.-Apr. 1969)

36. Equilibrium in the alumina-Al system

V. K. Kulifeev and G. A. Ukhlinov

Izv. Vyssh. Uchebn. Zaved., Tsvet. Met. 12 [2], 72-75 (Mar.-Apr. 1969)

37. X-ray diffraction study of the $\mathrm{V}-\mathrm{Cr}-\mathrm{B}, \mathrm{Nb}-\mathrm{Cr}-\mathrm{B}$ and Mo-Cr-B systems Yu. B. Kuzma, V. S. Telegus and D. A. Kovalyk

Porosh. Met. 9 [5], 79-87 (May 1969) 
G. 38. Activity-composition relations in solid Cu-Pt alloys as derived from equilibrium measurements in the system Cu-Pt-O at 1000 and $1200{ }^{\circ} \mathrm{C}$

C. Land olt and A. Muan (Pennsylvania State Univ., Univ. Park, Pa.) Trans. Met. Soc. AIME 245 [4], 791-96 (1969)

39. Solubility of $\mathrm{H}_{2}$ in $\mathrm{Ni}-\mathrm{Mo}$ and $\mathrm{Ni}-\mathrm{W}$ alloys

K. W. Lange and H. Schenck (Inst. Eisenhüttenw., Rhein.-Westfäl. T. H. Aachen, Germ.)

Z. Metallk. 60, 62-68 (1969)

40. New compounds in the $\mathrm{La}_{2} \mathrm{O}_{3}-\mathrm{SrO}$ and $\mathrm{Ce}_{2} \mathrm{O}_{3}-\mathrm{SrO}$ systems

L. M. Lopato, V. N. Pavlikov and L. I. Lugin

Zh. Neorg. Khim. 14 [3], 861-62 (1969)

41. Phase composition of the $\mathrm{Y}_{2} \mathrm{O}_{3}-\mathrm{Ta}_{2} \mathrm{O}_{5}$ system

L. N. Lykova and N. S. Afonskii (Lomonosov State Univ., Moscow)

Zh. Neorg. Khim. 14 [5], 1419 (1969)

42. Observations on the system $\mathrm{Zn}-\mathrm{Sn}-\mathrm{N} 1$

A. Mayer, U. Agnelil and G. Rocco (Univ. Trieste, Inst. Chim., Trieste, Italy)

Ann. Chim. (Rome) 59 [1], 52-80 (1969)

43. Phase relations in the $\operatorname{Ru}-\operatorname{Ir}-\mathrm{O}_{2}$ system in air

C. L. McDaniel and S. J. Schneider (Inst. Mater. Res., Nat. Bur. Standards, Washington, D. C. 20234)

J. Res. Nat. Bur. Std. $\underline{73 A}$ [2], 213-19 (1969)

44. Solubility of nitrogen in $V$

F. M. Monroe and J. R. Cost (Ford Sci. Lab., Dearborn, Mich.)

Trans. Met. Soc. AIME 245 [5], 1079-82 (1969)

45. Crystal chemistry of compounds in the systems $\mathrm{Tc}-0, \mathrm{Ln}_{2} \mathrm{O}_{3}-\mathrm{ReO}_{2}$, $\mathrm{MeO}-\mathrm{Cr}_{2} \mathrm{O}_{3}-\mathrm{O}, \mathrm{Pt}-\mathrm{O}, \mathrm{Rh}-\mathrm{O}$ and $\mathrm{Au}-\mathrm{O}$

0. Muller (Pennsylvania State Univ., 1968)

Dissertation Abstr. 29B [10], 3705 (1968-69)

46. The neodymium molybdate-tungstate system

K. Nassau, P. B. Jamies on and J. W. Shiever (Bell Te1. Labs., Murray Hill, N. J.)

J. Phys. Chem. Solids 30, 1225-35 (1969)

47. Studies on the $\mathrm{Zr}-\mathrm{C}$ system

H. Nickel, Ö. Inanc and $\mathrm{K}$. Lücke (Inst. Reaktorwerkstoffe, Kernforschungsanlage Jülich $\mathrm{GmbH}$ )

Z. Nieta11k. 59, 935-40 (1968)

48. Phase changes in the $\mathrm{ZrO}_{2}-\mathrm{TiO}_{z}$ system

T. Noguch1 and M. Mizuno (Govt. Ind. Res. Inst., Nagoya, Japan)

Bu11. Chem. Soc. Japan 41 [12], 2895-99 (1968) 
49. Reactions in the system $\mathrm{ZrO}_{2}-\mathrm{SrO}$

T. Noguchi, T. Okkubo and 0. Yonemochi (Govt. Ind. Res. Inst., Nagoya, Japan)

J. Am. Ceram. Soc. $\underline{52}[4], 178-81$ (1969)

50. Predicting ternary phase diagrams and quaternary excess free-energy using binary data

N. J. Olson and G. W. Toop (Met. Eng. Dept., Univ. of Washington, Seattle, Wash.)

Trans. Met. Soc. AIME 245 [5], 905-10 (1969)

51. Constitution diagram of the TaC-Re system

S. S. Ordanyan, N. V. Kosterova and A. I. Avgustinik

Izv. Akad. Nauk SSSR, Neorg. Mater. $\underline{5}$ [2], 389-90 (1969)

52. The Ga-GaAs-GaP system: phase chemistry and solution growth of $\mathrm{GaAs}_{x} \mathrm{P}_{1-x}$

M. B. Panish (Bell Tel. Labs., Murray Hill, N. J.)

J. Phys. Chem. Solids 30, 1083-90 (1969)

53. Phase and thermodynamic properties of the Ga-AI-P system. Solution epitaxy of $\mathrm{Ga}_{x} \mathrm{Al}_{1-x} \mathrm{P}$ and $\mathrm{AIP}$

M. B. Panish, R. T. Lynch and S. Sumski (Bell Tel. Lab., Murray Hill, N. J.)

Trans. Met. Soc. AIME 245 [3], 559-63 (1969)

54. Phase equilibria in the $\mathrm{HfO}_{2}-\mathrm{SiO}_{2}$ system

V. N. Parfenenkov, R. G. Grebenshchikov and N. A. Toropov

(Grebenshchikov Silicate Chem. Inst., Leningrad, USSR)

Dokl. Akad. Nauk SSSR 185 [4], 840-42 (1969)

55. Interaction between $\mathrm{W}, \mathrm{Cu}, \mathrm{Mn}, \mathrm{Ag}$ and $\mathrm{Sn}$

I. E. Petrunin and L. L. Grzhimalskii

Metallov. Term. Obrab. Metal. [1], 21-24 (Jan. 1969)

56. Dilatometric investigation of phase transformations in Fe-Ir alloys E. A. Plekhanova, S. Kh. Kurumchina and V. F. Egolaev

Fiz. Metal. Metallov. 27 [3], 473-77 (1969)

57. Solubility of $\mathrm{C}$ in $\mathrm{FeO}$

J. P. Plumens 1, A. Kohn, G. Vagnard and J. Manenc

Corros. Sci. 9 [5], 309-14 (1969)

58. The $\mathrm{Cr}-\mathrm{B}$ phase diagram

K. I. Portnoi, V. M. Romashov and I. V. Romanovich

Porosh. Met. 9 [4], 51-57 (April 1969)

59. Solubility of $\mathrm{Zr}$ in $\mathrm{Ag}$

N. L. Pravoverov and Yu. G. Kolon in

Izv. Akad. Nauk SSSR, Metal. [2], 188-90 (Mar.-Apr. 1969) 
G. 60. Investigations in the binary systems $\mathrm{La}_{2} \mathrm{O}_{3}-(\mathrm{CaO}, \mathrm{SrO}, \mathrm{BaO})$

G. Purt and E. Modern (Cerberus AG, Männedorf, Switzerland)

Monatsh. Chem. 99, 2171-74 (1968)

61. Intermediate compound $\mathrm{Ni}_{8} \mathrm{Nb}$ in $\mathrm{Ni}-\mathrm{rich} \mathrm{Ni}-\mathrm{Nb}$ alloys

W. E. Quist, C. J. van der Wekken, R. Taggart and D. H. Polonis

(Met. Eng. Dept., Univ. of Washington, Seattle, Wash.)

Trans. Met. Soc. AIME 245 [2], 345-49 (1969)

62. Solid solubility in the system zircon-hafnon

S. S. Ramakrishnan, K. V. G. K. Gokhale and E. C. Subbarao

(Indian Inst. Tech., Kanpur (U.P.), India)

Mater. Res. Bu11. 4 [5], 323-27 (1969)

63. The oxyfluoride of trivalent thorium ThOF. Study of the ThOF-ThO $\mathrm{T}_{z}$ $\mathrm{ThF}_{4}$ diagram

J. P. Rannou and J. Lucas (Lab. Chim. Minér. D, Fac. Sci. Rennes, 35-Rennes, Fr.)

Mater. Res. Bul1. 4 [7], 443-50 (1969)

64. Study of the $\mathrm{Zr}-\mathrm{Nb}-\mathrm{V}$ system with the electron-probe microanalyzer

G. N. Ronami, S. M. Kuznetsova, E. M. Sokolovskaya and M. V.

Raevskaya (State Univ., Solid State Phys. Dept., Moscow)

Vest. Most. Univ., Fiz. Astron. [2], 16-26 (Mar.-Apr. 1969)

65. Formation of binary and ternary solid solutions by the sesquioxides of $\mathrm{Cr}, \mathrm{Al}$ and $\mathrm{Fe}$. II. The system $\mathrm{Al}_{2} \mathrm{O}_{3}-\mathrm{Cr}_{2} \mathrm{O}_{3}$

A. Rousset and J. Pâris (Fac. Sci. Lyon, 69-Villeurbanne, Fr.)

Bull. Soc. Chim. France, 4009 (1968)

66. Temperature dependence of the electrical conductivity of cubic SiC M. S. Saidov, K. A. Shamauratov and V. V. Nikitin

Izv. Akad. Nauk Uzb.SSR, Ser. Fiz.-Mat. Nauk 13 [2], 72-73 (1969)

67. Stability region of topaz $\left[\mathrm{Al}_{2} \mathrm{SiO}_{4} \mathrm{Fe}_{X}(\mathrm{OH})_{2-x}\right]$

H. Saito and M. Ushio (Appl. Chem. Dept., Fac. Eng., Univ. of Nagoya, Japan)

Yogyo Kyokai Shi $\underline{76}$ [878], 337-50 (1968)

68. Non-stoichiometry of MnO in thermal equilibrium

N. G. Schmah1 and D. Hennings (Inst. Phys. Chem., Univ. Saarlandes, Saarbrücken, Germ.)

Z. Phys. Chem. (Frankfurt) 63, 111-24 (1969)

69. $\mathrm{Mn}_{3} \mathrm{O}_{4}-\mathrm{MnRh}_{2} \mathrm{O}_{4}$ solid solutions in the ternary system $\mathrm{Mn}-\mathrm{Rh}-\mathrm{O}$ N. G. Schmah1, D. Hennings and W. Schneider (Inst. Phys. Chem.,

Univ. Saarlandes, Saarbrücken, Germ.)

Z. Phys. Chem. (Frankfurt), 63, 125-31 (1969)

70. Co-rich ternary phases in the systems Co-Hf-B and Co-Zr-B J. -D. Schöbel and H. H. Stadelmaier (Eng. Res. Dept., North

Carolina State Univ., Raleigh, N. C.)

Metal1 23, 25-27 (1969) 
G. 71. Glass formation in the $\mathrm{Cs}_{2} \mathrm{O}-\mathrm{Al}_{2} \mathrm{O}_{3}$ system

N. N. Semenov

Izv. Sib. Otd. Akad. Nauk SSSR, Ser. Khim. Nauk [2], 148-50 (1969)

72. Phase relations in the system $U-S-0$

P. D. Shalek (Univ. of Illinois, 1968)

Dissertation Abstr. 29B [8], 2861 (1968-69)

73. Phase equilibrium diagram of the system Hf-Mn

A. K. Shurin and G. P. Dmitrieva (Acad. Sci., Metallophys. Inst., Kiev, UkSSR)

Dopovidi Akad. Nauk Ukr. RSR, Ser. A-Fiz. Tekh. Mat. Nauk [1], 67-69 (1969)

74. High temperature reactions and phase equilibria in the $\mathrm{SrO}^{-} \mathrm{ZrO}_{2}$ system

W. C. Simmons (Ohio State Univ., 1968)

Dissertation Abstr. 29B [9], 3299-3300 (1968-69)

75. Solid solutions in the $\mathrm{Y}_{2} \mathrm{Si}_{2} \mathrm{O}_{7}-\mathrm{Y}_{2} \mathrm{Ge}_{2} \mathrm{O}_{7}$ sys tem

A. N. Sokolov, N. A. Toropov and R. G. Grebenshchikov (Lensovet

Tech. Inst., Leningrad, USSR)

Dok1. Akad. Nauk SSSR 185 [1], 107-10 (1969)

76. Phase studies in the system $\mathrm{BaO} \cdot \mathrm{Fe}_{2} \mathrm{O}_{3}-\mathrm{Fe}_{2} \mathrm{O}_{3}$

H. Stäblein and W. May (Fr. Krupp GmbH, Zentralinst. Forschung und Entwicklung, Essen, Germ.)

Ber. Deut. Keram. Ges. 46, 69-74 (1969)

77. The T-phase in the $\mathrm{Ni}-\mathrm{Mn}-\mathrm{B}$ system

H. H. Stadelmaier (Eng. Res. Dept., North Carolina State Univ., Raleigh, N. C.)

Metall 23, 11-13 (1969)

78. Diagram of the Cr-Nd system

V. N. Svechnikov, G. F. Kobzenko, E. L. Martynchuk and V. G. Ivanchenko (Acad. Sci., Metallophys. Inst., Kiev, UkSSR)

Dopovidi Akad. Nauk Ukr. RSR, Ser. A-Fiz. Tekh. Mat. Nauk [1], 61-63 (1969)

79. The diagram of state for Fe-Al solid solutions

P. R. Swann, W. R. Duff and R. M. Fisher

Trans. Met. Soc. AIME 245 [4], 851-53 (1969)

80. The solubility of graphite and cementite in $(\alpha, \delta) \mathrm{Fe}$

J. C. Swartz (U.S. Steel Lab. Fundmtl. Res., Monroeville, Pa.)

Trans. Met. Soc. AIME 245 [5], 1083-87 (1969)

81. Phase transitions in the highly basic part of the CaO-SiO $\mathrm{O}_{z}$ system M. M. Sychev, V. I. Korneev and L. B. Baigalina

Izv. Vyssh., Ucheb. Zaved., Khim. Khim. Tekhno1. 11 [12], 1370-75 (1968) 
G. 82. The $\mathrm{Cr}-\mathrm{Re}-\mathrm{B}$ ternary system

V. S. Telegus, Yu. B. Kuzma and T. K. Stefanishina

Porosh. Met. 9 [2], 64-69 (Feb. 1969)

83. The solubility of $\mathrm{MgO}$ in the metastable cubic $\mathrm{ZrO}_{2}$ obtained at low temperature

M. Therasse and G. Monte1 (Dépt. Chim. Inorg., 31-Toulouse, Fr.)

C. R. Acad. Sci. 268C, 495 (1969)

84. Solid solution in the $\mathrm{Si}_{3} \mathrm{~N}_{4}-\mathrm{SiO}_{2}$ system

N. C. Tombs, F. A. Sewe11, Jr. and J. J. Comer (Sperry Rand Res. Ctr., Sudbury, Mass.)

J. Electrochem. Soc. 116 [6], 862-63 (1969)

85. Solid solutions in the $\mathrm{Y}_{2} \mathrm{SiO}_{5}-\mathrm{Y}_{2} \mathrm{GeO}_{5}$ sys tem

N. A. Toropov, R. G. Grebenshchikov and A. N. Sokolov

Izv. Akad. Nauk SSSR, Neorg. Mater. 5 [2], 321-24 (1969)

86. Solid solutions in the $\mathrm{Nd}_{2} \mathrm{SiO}_{5}-\mathrm{Nd}_{2} \mathrm{GeO}_{5}$ system

N. A. Toropov and M. V. Kougiya

Izv. Akad. Nauk SSSR, Neorg. Mater. 5 [2], 398-400 (1969)

87. The Ti-rich corner of the Ti-Al-V system

T. Tsujimoto (Nat. Res. Inst. Met., Tokyo)

Nippon Kinzoku Gakkai Shi 32 [10], 970-75 (1968)

88. Phase diagram of mixed uranium oxide-sodium fluoride system

V. K. Valtsev (Acad. Sci., Inorg. Chem. Inst., Novosibirsk, USSR)

Zh. Neorg. Khim. 14 [2], 581-83 (1969)

89. Metastability of high cristobalite in vitreous silica

F. E. Wagstaff (G. E. R/D Ctr., Schenectady, N. Y.)

Phys. Chem. Glasses 10, 50-53 (1969)

90. Phase equilibria in a portion of the system $\mathrm{Fe}-\mathrm{C}-\mathrm{O}$ from 250 to 10,000 bars and 400 to $1200^{\circ} \mathrm{C}$ and its petrologic significance

J. R. Weidner (Pennsylvania State Univ., 1968)

Dissertation Abstr. 29B [10], 3708-09 (1968-69)

91. Coherent and incoherent precipitation in the Au-Pt system

J. Weise and V. Gerold (Max Planck Inst. Metallforsch., Stuttgart, Germ.)

Z. Meta11k. 59, 904-09 (1968)

92. $\mathrm{CaCl}_{2}-\mathrm{rich}$ region of the $\mathrm{CaCl}_{2}-\mathrm{CaF}_{2}-\mathrm{CaO}$ system

D. A. Wenz, I. Johnson and R. D. Wolson (Argonne Nat. Lab., Argonne, I11. 60439)

J. Chem. Eng. Data 14 [2], 250-52 (1969)

93. Phase diagram of the $\mathrm{MgO}-\mathrm{V}_{2} \mathrm{O}_{\bar{B}}$ system

R. Wollast and A. Tazairt (Univ. Libre de Bruxelles, Belg.)

Silicates Ind. 34, 37 (1969) 
G. 94. Phase diagram of the La-Se system

E. I. Yarembash, E. S. Vigileva, R. R. Kagramanova and L. Kh. Kravchenko

Izv. Akad. Nauk SSSR, Neorg. Mater. $\underline{5}$ [2], 260-64 (1969)

95. Refinement of the metastable equilibrium diagram of the Fe-C-Si system

A. A. Zhukov

Izv. Akad. Nauk SSSR, Meta1. [2], 155-58 (Mar.-Apr. 1969)

H. Reactions at temperatures above $1000^{\circ} \mathrm{C}$

1. Action of $\mathrm{Fe}$ as a promoter of carbon graphitization

P. Albert (Carbone Lorraine, Paris)

J. Chim. Phys. [Special No.], 171 (April 1969)

2. Investigation of the formation of $\mathrm{TI}$ and $\mathrm{Zr}$ carbides during reduction of chlorides by $\mathrm{H}_{2}$ on a graphite substrate

R. S. Ambartsumyan and B. N. Babich

Izv. Akad. Nauk SSSR, Neorg. Mater. 5 [2], 301-04 (1969)

3. Oxidative calcination of $\mathrm{Zn}-\mathrm{V}$ spinel

S. A. Amirova, V. G. Prokhorova, V. P. Kudryashov and T. G. Danilova (Polytech. Inst., Perm, USSR)

Zh. Neorg. Khim. 14 [2], 315-19 (1969)

4. On Si transfer from molten slag to molten iron

M. Ashizuka, M. Tokuda and M. Ohtani (Res. Inst. Miner. Dressing and Met., Tohoku Univ., Sendai, Japan)

Tetsu To Hagane $\underline{54}$ [14], 1437-46 (1968)

5. Reaction of Si melts with high-melting metals

A. I. Avgustinik, G. I. Zhuravlev and I. A. Matusov

Zh. Prikl. Khim. 42 [3], 689-90 (1969)

6. The diffusion of $\mathrm{Fe}, \mathrm{Ni}$ and $\mathrm{Co}$ in the Fe-group transition metals M. Badia and A. Vignes (E.N.S. Mét. et Ind. Mines Nancy, Univ. de Nancy, Fr.)

Acta Met. 17 [2], 177-87 (1969)

7. Synthesis and optical properties of $\mathrm{YAlO}_{3}$ crystals activated by $\mathrm{Nd}^{3+}$ ions

Kh. S. Bagdasarov, A. A. Kaminskii and G. I. Rogov (Acad. Sci., Cryst. Inst., Moscow)

Dokl. Akad. Nauk SSSR $\underline{185}$ [5], 1022-24 (1969)

8. Cation diffusion in fluorite single crystals

M. Baker and A. Taylor (Mater. Sci. Dept., Cornell Univ., Ithaca, N. Y.)

J. Phys. Chem. Solids 30, 1003-07 (1969) 
H. 9. Synthesis and investigation of $(\mathrm{Y}, \mathrm{Nd})_{3} \mathrm{Al}_{5} \mathrm{O}_{13}$ solid solutions R. V. Bakradze, L. M. Kovba, G. P. Kuznetsova and V. V. Bratsev Dok1. Akad. Nauk SSSR 185 [5], 1049-51 (1969)

10. The reaction between $\mathrm{ZrO}_{2}$ and the iron oxides at high temperatures D. Becherescu and $\mathrm{F}$. Winter

Silicates Ind. 34, 17 (1969)

11. Study of the flame-spraying of borides and nitrides with the plasma torch. II. Characteristics of the films

G. Bentz, G. Prevost and C. Urban (Soc. Air Liquide, Soc. Franc. Céram. and Soc. L. Desmarquest, Fr.)

Bul1. Soc. Franc. Céram. [81], 23 (1968)

12. Mechanisms of oxidation of Ta-low alloy coated with tungsten disilicide

J. B. Berkowitz-Mattuck (A. D. Little, Cambridge, Mass.)

J. Electrochem. Soc. 116 [5], 700-09 (1969)

13. Preparation and properties of a new trirutile oxide $\mathrm{Ta}_{2} \mathrm{CrO}_{6}$

J. C. Bernier and P. Massard (Fac. Sci., 91-Orsay, Fr.)

C. R. Acad. Sci. 268C, 498 (1969)

14. On the mechanism of formation of synthetic diamonds from graphite in the presence of metals

G. B. Bokil and A. I. Volkov

Kristallografiya 14 [1], 147-49 (1969)

15. Graphite and pyro-graphite reaction with $\mathrm{TI}$ and $\mathrm{Zr}$ nitrides

A. L. Borykina and T. M. Evtushok

Porosh. Met. 9 [5], 51-58 (May 1969)

16. Influence of mechanical properties of surface oxide films on oxidation mechanisms

D. Bruce and P. Hancock

J. Inst. Metals 97, 140-55 (1969)

17. The reaction of $\mathrm{Cr}$ with $\mathrm{N}_{2}$ at elevated temperatures

L. Cadiou and J. Paidassi (C.E.N. Saclay, 91-Gif/Yvette, Essonne, Fr.)

C. R. Acad. Sci. 268C, 743 (1969)

18. Interdiffusion studies on $\mathrm{Cu}_{2} \mathrm{O}$ and $\mathrm{FeO}$

R. H. Campbell (Arizona State Univ., 1969)

Dissertation Abstr. 29B [10], 3696-97 (1968-69)

19. Oxygen self-diffusion in CoO

W. K. Chen and R. A. Jackson (Met. Div., Argonne Nat. Lab., Argonne, II1. 60439)

J. Phys. Chem. Solids 30, 1309-14 (1969) 
H. 20. The oxidation of $\mathrm{Zr}$ at high temperatures. The oxidation kinetics of $\mathrm{Zr}$ powder in $\mathrm{O}_{2}$ and $\mathrm{CO}_{2}$ atmosphere

D. Cismaru and E. Dobroghiu (Acad. Sc1., Inst. Phys. Chem., Bucharest, Roumania)

Rev. Roumaine Chim. 14 [3], 291-96 (1969)

21. $\mathrm{SiO}_{2}$ thermally grown in a silicon nitride ambient

R. A. Cohen (MIT Lincoln Lab., Lexington, Mass.) and R. Wheeler (Sprague Electric Co., Worcester, Mass.)

J. Electrochem. Soc. 116 [4], 506 (1969)

22. Self-diffusion and solute diffusion of La, Ho and In in BCC $\operatorname{Pr}$ and of Au in FCC La

M. Darle1, G. Erez and G. M. J. Schmidt (Nucl. Res. Ctr., Negev, Israe 1)

Ph11. Mag. 19, 1045-59 (1969)

23. Interaction between US and $\mathrm{N}_{2}$

Z. Despotovic and Z. Ban

Croat. Chem. Acta 41 [1], 25-29 (1969)

24. Kinetics and mechanism of high-temperature reactions of kaolinite minerals

J. F. Duncan, K. J. D. Mackenzie (Chem. Dept., Victoria Univ. of Wellington, New Zealand) and P. K. Foster (New Zealand Pottery \& Ceram. Res. Assoc., Lower Hutt, New Zealand)

J. Am. Ceram. Soc. 52 [2], 74-77 (1969)

25. High pressure, high temperature syntheses of rare earth diantimonides and $\mathrm{Th}_{3} \mathrm{P}_{4}$-type polymorphs of rare-earth sesquisulfides

N. L. Eatough (Brigham Young Univ., 1968)

Dissertation Abstr. 29B [8], 2826 (1968-69)

26. Kinetics of the reaction of $\mathrm{ZrO}_{2}$ with $\mathrm{C}$ at high temperatures V. P. Elyutin, Yu. A. Pavlov, A. V. Manukhin and V. F. Melekhin Izv. Vyssh. Ucheb. Zaved., Chern. Met. 12 [3], 5-9 (Mar. 1969)

27. Oxidation behavior of $\mathrm{Cr}-\mathrm{Al}-\mathrm{Y}$ alloys

E. J. Felten (Advanced Mater. R/D Lab., Pratt \& Whitney Alrcraft, Middletown, Conn.)

Trans. Met. Soc. AIME 245 [6], 1349-55 (1969)

28. The influence of high temperature plastic deformation on the kinetics of graphitization of pyrolytic carbons

D. B. Fischbach (Calif. Inst. Tech., Pasadena, Calif.)

J. Chlm. Phys. [Special No.], 121 (Apri1 1969)

29. Electrotransport and diffusion in Mo-W and Fe-Ni alloys

I. N. Frantsevich, D. F. Kalinovich, I. I. Kovenskil and M. D. Smolin (Inst. Mater. Sci., Acad. Sc1., Klev, UkSSR)

J. Phys. Chem. Solids 30, 947-57 (1969) 
H. 30. Diffusion of Mn in molten $\mathrm{Cu}$

M. G. Frohberg and J. Poetschke

Z. Naturforsch. 24A [4], 679-81 (1969)

31. Reduction and oxidation equilibria between divalent and trivalent chromium in molten $\mathrm{CaO}-\mathrm{SiO}_{2}$-chromium oxide slags

M. G. Frohberg and K. Richter (Inst. Allg. Met., Tech. Univ., Berlin)

Arch. Eisenhüttenw. 39, 799-802 (1968)

32. Preparation of stabilized cubic $\mathrm{ZrO}_{2}$

Yu. M. Galkin, V. G. Chukhlantsev and Yu. M. Polezhaev (Kirov

Polytech. Inst., Sverdlovsk, USSR)

Zh. Prik1. Khim. 42 [3], 682-83 (1969)

33. Mechanism of the surface siliciding of $W$

C. Gelain, A. Cassuto and P. Le Goff (Ctr. Cinét. Phys. et Chim., CNRS, Villers, Nancy, Fr.)

Bu11. Soc. Franc. Céram. [80], 23 (1968)

34. Kinetics of $O_{z}$ evolution at a $P t$ anode in lithium silicate melts A. Ghosh and T. B. King (Mass. Inst. Tech., Cambridge, Mass.)

Trans. Met. Soc. AIME 245 [1], 145-52 (1969)

35. Preparation of single crystals of $\mathrm{FeCr}_{2} \mathrm{~S}_{4}$

P. Gibart and A. Begouen-Demeaux (Fac. Sci., 21-Dijon, Côte d'Or, Fr.)

C. R. Acad. Sci. 268C, 816 (1969)

36. The oxy-reactivity of vitreous carbon

F. Girard and H. Guerin (Fac. Sci. Orsay, Fr.)

Bul1. Soc. Chim. France 3982 (1969)

37. Contact interaction of SiC with molten $\mathrm{Cu}$

G. G. Gnesin and Yu. V. Naidich

Porosh. Met. $\underline{9}$ [2], 57-63 (Feb. 1969)

38. Hedvall effect and synthesis of zircon

K. Gokhale, S. V. Ramani and E. C. Subbarao (Indian Inst. Tech., Kanpur)

J. Mater. Sci. 4, 468-69 (1969)

39. Interstitial compounds

H. J. Goldschmidt (B.S.A. Res. Ctr., Birmingham, U. K.)

J. Inst. Metals 97, 173-79 (1969)

40. On the rate of decarburization of liquid metals with $\mathrm{CO}-\mathrm{CO}_{2}$ gas mixture

K. Goto, M. Kawakami and M. Someno (Met. Eng. Dept., Tokyo Inst. Tech., Meguro-ku, Tokyo)

Trans. Met. Soc. AIME 245 [2], 293-301 (1969) 
H. 41. Interdiffusion in the system $\mathrm{MgO}^{-} \mathrm{Cr}_{2} \mathrm{O}_{3}$

C. Greskovich and V. S. Stubican (Mater. Sci. Dept., Pennsylvania

State Univ., Univ. Park, Pa. 16802)

J. Phys. Chem. Solids 30, 909-17 (1969)

42. Catalysis of the graphitization of certain carbons by the mixture $\mathrm{Cr}, \mathrm{O}_{2}$ and $\mathrm{S}$

J. Guillot and B. Lux (Inst. Battelle, Geneva)

J. Chim. Phys. [Special No.], 172 (April 1969)

43. Reaction of nitrides with oxygen and oxides

Yu. G. Gurevin

Izv. Vyssh. Ucheb. Zaved., Chern. Met. 11 [12], 18-22 (Dec. 1968)

44. Interdiffusion in Fe-Ti alloys

K. Hirano and Y. Ipposhi (Mater. Sci. Dept., Fac. Eng., Tohoku Univ., Sendai, Japan)

Nippon Kinzoku Gakka1 Shi 32 [9], 815-21 (1968)

45. Capillary seed technique in crystal pulling

S. E. R. Hiscocks (Royal Radar Estab1., Great Malvern, U. K.)

J. Mater. Sci. 4, 310-12 (1969)

46. Emission of high-energy electrons during alloy-evaporation processes on hot metal filaments

S. A. Hoenig and R. A. Pope (Electr. Eng. Dept., Univ. of Arizona, Tucson, Ariz. 85721)

App1. Phys. Letters 14 [9], 271-72 (1969)

47. Oxidation kinetics of powdered silicon nitride

R. M. Horton (Met. Dept., Washington State Univ., Pullman, Wash. 99163)

J. Am. Ceram. Soc. $\underline{52}[3], 121-24$ (1969)

48. Kinetics of degassing of $\mathrm{V}-0$ solid solutions

G. Hörz (Max Planck Inst. Metallforsch., Stuttgart, Germ.)

Z. Metallk. 60, 50-57 (1969)

49. Initial stresses in high temperature oxidation of $\mathrm{Fe}-\mathrm{Cr}$ alloys V. R. Howes and C. N. Richards on (C.E.R.L., Lea therhead, U. K.) Corrosion Sci. 9, 385-94 (1969)

50. Relation between growth temperature and the structure of SiC crystals grown by sublimation method

Y. Inomata, Z. Inoue, M. Mitomo and H. Suzuki (Nat. Inst. Res. Inorg. Mater., Tokyo)

Yogyo Kyokai Shi 76 [877], 313-19 (1968)

51. Effect of the growth rate on the structure and stacking disorder of SiC crystals grown in the cavity of Lely's procedure

Y. Inomata, H. Komatsu, Z. Inoue and M. Mitomo (Nat. Inst. Res. Inorg. Mater., Tokyo)

Yogyo Kyokai Shi 76, [876], 268-76 (1968) 
H. 52. Growth process of SiC crystals prepared by sublimation method Y. Inomata, M. Mitomo, Z. Inoue and H. Tanaka (Nat. Inst. Res. Inorg. Mater., Tokyo)

Yogyo Kyokai Shi $\underline{76}$ [878], 355-62 (1968)

53. Production of refractory crystals by chemical transport reactions J. H. E. Jeffes and C. B. Alcock (Imperial College, London)

Bu11. Soc. Franc. Céram. [80], 31 (1968)

54. High pressure hot-pressing refractory materials

D. Kalish and E. V. Clougherty (ManLabs Inc., Cambridge, Mass.) Am. Ceram. Soc. Bull. 48 [5], 570-78 (1969)

55. Effect of pressure on graphitization of carbon. IV. Abrupt graphitization of hard carbon under $5 \mathrm{Kbar}$

K. Kamiya, M. Inagaki, M. Mizutani and T. Noda (Fac. Eng., Univ. of Nagoya, Japan)

Bu11. Chem. Soc. Japan 41 [9], 2169-72 (1968)

56. Gallium ion diffusion in MgO

G. Katz, S. Kachi and R. Roy (Israel Mining Ind. R/D Inst., Haifa, Israe1)

Japan. J. App1. Phys. 8 [4], 429-35 (1969)

57. Preparation and properties of interstitial compounds

R. Kieffer (Inst. Chem. Tech., Tech. Hochschule Wien, Austria)

J. Inst. Metals 97, 164-72 (1969)

58. Carbothermic reduction of silica

T. Kikuchi, T. Kurosawa and T. Yagihashi (Nat. Res. Inst. Met., Meguro-ku, Tokyo)

Rept. Nat. Res. Inst. Met. 11 [6], 27-34 (1968); Nippon Kinzoku Gakkai Shi 32 [9], 866-72 (1968)

59. Action of a molten basic open hearth slag with a composition in the $\mathrm{MgO}-\mathrm{MgAl}_{2} \mathrm{O}_{4}-\mathrm{MgCr}_{2} \mathrm{O}_{4}$ sys tem

Ya. V. Klyucharov and Yu. D. Kuznetsov

Ogneupory 34 [4], 48-52 (April 1969)

60. Microstructural changes in UN fuel elements under the influence of a temperature gradient

T. Kubota and S. Takahashi (Mitsubishi Atomic Power Ind. Res. and Eng. Lab., Omiya, Japan)

Nippon Kinzoku Gakkai Shi 32 [7], 665-69 (1968)

61. On the exchange of matter between ascending globular bubbles and liquid metal melts

K. W. Lange, M. Ohji, D. Papamantellos and H. Schenck (Inst.

Eisenhüttenw., Rhein. -Westfä1. T. H. Aachen, Germ.) Arch. Eisenhüttenw. 40, 99-107 (1969) 
H. 62. Kinetics of the graphite $-\mathrm{UO}_{2}$ reaction from 1400 to $1756{ }^{\circ} \mathrm{C}$

T. L. Lindemer, M. D. Allen and J. M. Leitnaker (Metals \& Ceram.

Div., Oak Ridge Nat. Lab., Oak Ridge, Tenn. 37830)

J. Am. Ceram. Soc. $\underline{52}[5], 233-37$ (1969)

63. Interaction of $\mathrm{Fe}, \mathrm{Mn}$ and $\mathrm{Si}$ with magnesite refractories

T. I. Litvinova, T. F. Raichenko and V. P. Pirozhkova

Ogneupory 34 [4], 52-56 (April 1969)

64. Reduction of high-alumina refractories in Fe-C melts

H. Maas and H. Abratis (Forschungsabt., Rheinstahl Hüt tenwerke AG, Hattingen, Germ.)

Arch. Eisenhüttenw. 40, 153-57 (1969)

65. Transformation of pyrocarbon to graphite

J. Maire and J. Rappeneau (Carbone Lorraine, Gennevilliers and C.E.A., Saclay, Fr.)

J. Chim. Phys. [Special No.], 141 (April 1969)

66. Irreversible thermal decomposition reactions of some oxides

G. I. Malinin and Yu. M. Tolmachev

Zh. Neorg. KhIm. 14 [2], 307-10 (1969)

67. Synthesis of $\mathrm{ZrB}_{2}$ by chemical vapor deposition

T. Manabe and T. Gejo (Ctr. Res. Lab., Hitachi Ltd., Kokubunji, Tokyo)

Yogyo Kyokai Shi $\underline{76}[877], 324-30$ (1968)

68. Mg-thermal method for obtaining metal borides

I. Ya. Markovsky, N. V. Vekshina, E. T. Bezruk, G. V. Sukhareva and T. K. Voevods kaya

Porosh. Met. 9 [5], 13-18 (May 1969)

69. Formation of AIN by use of a transferred plasma torch

0. Matsumoto (Aoyama Gakuin Univ., Coll. Sci. \& Eng., Dept. Chem., Tokyo)

J. Electrochem. Soc. Japan 36 [4], 207-12 (1968)

70. Formation of zirconium nitride with a $\mathbf{N}_{z}$ plasma jet

0. Matsumoto (Aoyama Gakuin Univ., Coll. Sci. \& Eng., Dept. Chem., Tokyo)

J. Electrochem. Soc. Japan 36 [4], 213-18 (1968)

71. Nitrization of $\mathrm{ZrO}_{2}$ by means of a nitrogen plasma jet

0. Matsumoto (Chem. Dept., Coll. Sci. \& Eng., Aoyama Gakuin Univ., Tokyo)

Denki Kagaku $\underline{36}$ [12], 877-83 (1968)

72. Nitrization of $\mathrm{TiO}_{z}$ by means of a nitrogen plasma jet

0. Matsumoto and Y. Shirato (Chem. Dept., Coll. Sci. \& Eng., Aoyama Gakuin Univ., Tokyo)

Denki Kagaku $\underline{36}$ [7], 519-27 (1968) 
H. 73. Formation of $\mathrm{AlN}$ by the reaction between $\mathrm{Al}_{2} \mathrm{O}_{3}$ and a $\mathrm{N}_{2}$ plasma jet

O. Matsumoto, Y. Shirato and M. Miyazaki (Aoyama Gakuin Univ.,

Col1. Sci. \& Eng., Dept. Chem., Tokyo)

J. Electrochem. Soc. Japan 36 [4], 219-25 (1968)

74. Diffusivities of $O$ and $S$ in liquid $\mathrm{Fe}$

R. L. McCarron and G. R. Belton (Dept. Met. \& Mater. Sci., Univ. of Pennsylvania, Philadelphia, Pa.)

Trans. Met. Soc. AIME 245 [6], 1161-66 (1969)

75. Preparation and structure of the rare earth titanates

G. J. McCarthy, W. B. White and R. Roy (Mater. Res. Lab., Pennsylvania

State Univ., Univ. Park, Pa. 16802)

Mater. Res. Bull. 4 [4], 251-55 (1969)

76. Compounds of rare earth metals with elements of the nitrogen sub-group

K. E. Mironov (Inorg. Chem. Inst., Siber. Div.,Acad. Sci. USSR,

Novosibirsk 90, USSR)

Mater. Res. Bull. 4 [4], 257-64 (1969)

77. Determination of the activity of $\mathrm{Al}$ in liquid $\mathrm{A} 1-\mathrm{Fe}$ alloys by the bubbling method

H. Mitani and H. Nagai (Met. Dept., Fac. Eng., Univ. of Osaka, Japan)

Nippon Kinzoku Gakkai Shi 32 [8], 752-55 (1968)

78. Al diffusion in SiC

E. N. Mokhov, Yu. A. Vodakov and G. A. Lomakina (Acad. Sci., Inst. Semiconductors, Leningrad, USSR)

Fiz. Tverd. Tela 1 l $[2], 519-21$ (1969)

79. Diffusion in iron oxide melts

K. Mori and K. Suzuki (Fac. Eng., Univ. of Nagoya, Japan)

Tetsu To Hagane 54 [12], 1199-1203 (1968)

80. Oxidation kinetic studies of $\mathrm{ZnS}$ as a single particle and in a fluidized bed reactor

K. Natesan (Carnegie-Mellon Univ., 1968)

Dissertation Abstr. 29B [9], 3335 (1968-69)

81. Kinetics of the reaction of $\mathrm{Zr}$ with low-pressure $\mathrm{O}_{2}$ at high temperatures

J. Nierlich and J. Paidassi (C.E.N. Saclay, 91-Gif/Yvette, Essonne, Fr.)

C. R. Acad. Sci. 267C, 1429 (1968)

82. Influence of different factors on graphitization

T. Noda (Mie Univ., Tsu, Mie, Japan)

J. Chim. Phys. [Special No.], 151 (April 1969) 
H. 83. Study by electron microscopy and diffraction of the partial graphitization of hard carbons; effect of promoters

A. Oberlin, F. Rousseau and J. P. Rouchy (Fac. Sci. Paris)

J. Chim. Phys. [Special No.], 160 (April 1969)

84. Kinetic study of graphitization

A. Pacault, A. Marchand, H. Gasparoux, S. Flandrois and J. C. Rouillon (Ctr. Rech. Paul Pascal, 33-Talence, Fr.)

J. Chim. Phys. [Special No.], 104 (April 1969)

85. The reaction of $\mathrm{Cr}$ with $\mathrm{CO}_{2}$ at elevated temperatures

J. Paidassi, L. Cadiou and R. Darras (C.E.N. Saclay, 91-Gif/Yvette, Essonne, Fr.)

Mém. Sc1. Rev. Mét. 65, 833 (1968)

86. Diffusion of ${ }^{51} \mathrm{Cr}$ into $\mathrm{Nb}$ single crystals

J. Pelleg (Nat. Aero. Establ., Nat. Res. Council, Ottawa, Can.)

Phil. Mag. 19, 25-32 (1969)

87. Diffusion of $\mathrm{C}, \mathrm{N}$ and $\mathrm{O}$ in beta-Th

D. T. Peterson and T. Carnahan (Ames Lab., U.S. AEC, Ames, Iowa)

Trans. Met. Soc. AIME 245 [2], 213-15 (1969)

88. Production and investigation of single crystals of Be-doped SiC

I. G. Pichugin and N. A. Smirnova

Izv. Akad. Nauk SSSR, Neorg. Mater. 5 [2], 231-34 (1969)

89. Solid state reactions in lithium ferrite

A. J. Pointon and R. C. Saull (Phys. Dept., College of Tech., Portsmouth, Eng1.)

J.Am. Ceram. Soc. $\underline{52}[3], 157-60$ (1969)

90. The influence of reduced pressures of $\mathrm{CO}$ on the $\mathrm{C}-\mathrm{O}_{2}$ reaction in 0.21 pct $\mathrm{C}-\mathrm{Fe}$ melts

A. E. Rathke and S. K. Tarby (Lehigh Univ., Bethlehem, Pa.)

Trans. Met. Soc. AIME 245 [1], 119-26 (1969)

91. Oxidation of $\mathrm{W}$ during thermal cycling

R. E. Royce and E. F. I. Roberts (Cass College, London E.1.)

Corrosion Sci. 9, 357-61 (1969)

92. Growth of $\mathrm{Bi}_{12} \mathrm{FeO}_{20}$ single crystals and their optical properties A. I. Safonov, S. A. Baryshev, T. I. Nikiforova, G. N. Antonov and S. A. Fedulov

Kristallografiya $\underline{14}$ [1], 152 (1969)

93. Thermal field in single crystals of si during growth from the melt B. A. Sakharov, Yu. M. Shashkov and V. B. Silkin

Izv. Akad. Nauk SSSR, Neorg. Mater. $\underline{5}$ [2], 225-30 (1969) 
H. 94. Controlling of the equilibria between $\mathrm{C}$ and $\mathrm{O}_{2}$ in molten $\mathrm{Fe}$ by $\mathrm{Ni}, \mathrm{Cr}$ and $\mathrm{Si}$ in the temperature range of molten steel

H. Schenck, E. Steinmetz and P. Chang-Hee-Rhee (Inst. Eisenhüttenw., Rhein.-Westfäl. T. H. Aachen, Germ.)

Arch. Eisenhüttenw. 39, 803-08 (1968)

95. The phase diagram FeO-NiO and the equilibria between FeO-NiO- $\left(\mathrm{Al}_{2} \mathrm{O}_{3}\right)$ slags and $\mathrm{Fe}-\mathrm{Ni}$ melts at the temperature of steel-making H. Schenck, E. Steinmetz and R. Grundmann (Inst. Eisenhüttenw., Rhein.-Westfäl. T. H. Aachen, Germ.)

Arch. Eisenhüttenw. 39, 895-901 (1968)

96. Preparation of metallic Dy by reduction of its oxide with Th

G. Schiffmacher and F. Trombe (Lab. Terres Rares, 92-Bellevue, Hauts de Seine, Fr.)

C. R. Acad. Sci. 268C, 159 (1969)

97. The Importance of the temperature and FeO content of slags during the dissolution of lime in the basic open-hearth process

E. Schürmann, K. Nürnberg, W. Ullrich and E. Overkott (Inst. Giessereiwesen, Tech. Univ. Clausthal, Germ.)

Arch. Eisenhüttenw. 39 , 815-21 (1968)

98. Relative rate of $\mathrm{Cr}$ and $\mathrm{C}$ oxidation from $\mathrm{Fe}-\mathrm{Cr}-\mathrm{C}$ melts

Yu. S. Shchekalev, S. I. Popel and A. I. Pastukhov (Ural Ferrous

Met. Inst., Sverdlovsk, USSR)

Zh. Fiz. Khim. 43 [4], 1004-05 (1969)

99. Dissolution of alumina in C-saturated liquid Fe

A. Simkovich, K. Li and C. L. McCabe (Chem. Eng. Dept., CarnegieMellon Univ., Pittsburgh, $\mathrm{Pa}$. )

Trans. Met. Soc. AIME 245 [5], 897-903 (1969)

100. Formation of active carbon in twin-crucible studies of vanadium carbonitride solutions

K. E. Spear and J. M. Leitnaker (Metals \& Ceram. Div., Oak Ridge Nat. Lab., Oak Ridge, Tenn. 37830)

J. Am. Ceram. Soc. $\underline{52}[5], 257-62$ (1969)

101. Reaction rate of hydrogen with diamond powder

W. S. Stanko and J. C. Angus (Chem. Eng. Sci. Div., Case Western Reserve Univ., Cleveland, Ohio 44106)

J. Chem. Eng. Data 14 [2], 223-24 (1969)

102. Mass-spectrometric investigation of the reaction of $\mathrm{H}_{\mathcal{Z}}$ with graphite at $1900-2400{ }^{\circ} \mathrm{K}$

S. J. Steck, G. A. Pressley, Jr., S. S. Lin and F. E. Stafford (Chem. Dept. \& Mater. Res. Ctr., Northwestern Univ., Evanston, I11. 60201)

J. Chem. Phys. 50 [8], 3196-3207 (1969) 
H. 103. Mass spectrometric investigation of the high-temperature reaction of $\mathrm{H}_{2}$ with $\mathrm{B}_{4} \mathrm{C}$

S. J. Steck, G. A. Pressley, Jr. and F. A. Stafford (Chem. Dept. \& Mater. Res. Ctr., Northwestern UnIv•, Evanston, Ill. 60201)

J. Phys. Chem. 73 [4], 1000-08 (1969)

104. Growth of $\mathrm{Ni}-\mathrm{Ge}$ alloy single crystals from a melt

N. I. Sudakov, V. I. Kovrigin and B. A. Ayurzanain (Non-Ferrous

Metals Inst., Krasnoyarsk, USSR)

Kristallografiya 14 [2], 379 (1969)

105. Growth of $\mathrm{Co}_{3} \mathrm{O}_{4}$ single crystals and its reaction mechanism

T. Takada, Y. Bando, N. Yamamoto and K. Nagasawa (Kyoto Univ.,

Inst. Chem. Res., Uji, Kyoto, Japan)

Japan. J.App1. Phys. $\underline{8}$ [5], 619 (1969)

106. The effect of small amounts of $\mathrm{Be}$ on the high temperature oxidation of $80 \mathrm{Ni}-20 \mathrm{Cr}$ alloy

A. Takei and H. Takaishi (Nat. Res. Inst. Met., Meguro-ku, Tokyo)

Nippon Kinzoku Gakkai Shi 32 [12], 1221-28 (1968)

107. Role of chemical equilibria in the silico-thermic reduction of $\mathrm{MO}_{3}$ in the presence of $\mathrm{Fe}$

J. K. Thorne (Univ. of Michigan, 1968)

Dissertation Abstr. 29B [8], 2914-15 (1968-69)

108. The growing of single yttrium iron garnet crystals out of the $\mathrm{PbO}-\mathrm{PbF}_{2}-\mathrm{B}_{2} \mathrm{O}_{3}$ solvent

A. G. Titova and I. I. Sapozhnikov

Izv. Akad. Nauk SSSR, Neorg. Mater. 5 [3], 569-71 (1969)

109. Equilibria between iron and lime-saturated, sulfur-containing iron oxide slags at 1400 and $1600{ }^{\circ} \mathrm{C}$

G. Trömel, K. Koch and J. Gelseler (Inst. Eisenhüttenw., Tech. UnIv. Clausthal, Germ.)

Arch. Eisenhüttenw. 40, 87-98 (1969)

110. Oxidation of iron in oxygen-water vapour mixtures

C. W. Tuck, M. Odgers and K. Sachs

Corrosion Sci. 9, 271-85 (1969)

111. The synthesis of "carbonade" diamonds

L. E. Vereshchagin, E. N. Yakovlev, T. D. Varfolomeeva, V. N. Slesarev and I. E. Shterenberg (Acad. Sci., Inst. Phys. High Pressures, Moscow)

Dok1. Akad. Nauk SSSR 185 [3], 555-56 (1969)

112. Electroconductivity and diffusion coefficient of oxygen in $\mathrm{CeO}_{z}$ single crystals

I. V. Vinokurov and V. A. Joffe (Grebenshchikov Silicate Chem. Inst., Leningrad, USSR)

Fiz. Tverd. Tela 11 [2], 257-60 (1969) 
H. 113. Reaction of $\mathrm{MgO}$ and $\mathrm{Al}_{2} \mathrm{O}_{3}$ in high temperature gas flows V. A. Vishnevskaya, Z. Z. Konstant, T. N. Miller and A. Ya. Vaivad Latv. PSR Zinat. Akad. Vestis, Kim. Ser. [1], 14-18 (1969)

114. The behavior of $\mathrm{H}_{2}$ between gas, slags and steel in basic refining processes

H. von Emde, K. Hagen and H. Trenkler (Forschungsinst. Mannesmann AG, Duisburg-Huckingen, Germ.)

Arch. Eisenhüt tenw. 40, 27-36 (1969)

115. Chemical compatibility of $\mathrm{Ni}$ and Mo fibers with Be

C. R. Watts (Aerospace Corp., El Segundo, Calif.)

Trans. Met. Soc. AIME 245 [2], 329-33 (1969)

116. Growth of complex oxide single crystals from fluoride melts

E. A. Weaver and C. T. Li (Owens-Illinois, Inc., Toledo, Ohio 43601)

J. Am. Ceram. Soc. $\underline{52}[6], 335-38$ (1969)

117. Growth of $\mathrm{Fe}-\mathrm{Ni}$ oxide spinel single crystals by arc Image techniques E. A. Weaver, H. D. Merchant and R. P. Poplawsky (Unive of Toledo, Ohio 43606)

J. Am. Ceram. Soc. 52 [4], 214-15 (1969)

118. High pressure, high temperature synthesis of selected rare earth polysulfides and polyselenides

A. W. Webb (Brigham Young Univ., 1969)

Dissertation Abstr. 29B [10], 3708 (1968-69)

119. Microscopy studies of graphitization

E. M. Woodruff (Battelle Mem. Inst., Richland, Wash.)

J. Chim. Phys. [Special No.], 96 (April 1969)

120. Effect of raw gas pressure on the formation and structural

features of pyrolytic graphite

S. Yajima and T. Hirai (Res. Inst. Iron, SteeI \& Other Met.,

Tohoku Univ., Sendai, Japan)

Zairyo 17 [182], 1022-27 (1968)

121. Oxygen potentials of a jet interacting with an Fe-C melt

V. V. Yakovlev and S. I. Filippov

Izv. Vyssh. Ucheb. Zaved., Chern. Met. 11 [12], 14-17 (Dec. 1968)

122. Reaction of cubic carbides of $\mathrm{T} 1, \mathrm{~V}, \mathrm{Nb}$ and $\mathrm{Ta}$ with $\mathrm{Be}$

Yu. G. Zainulin, S. I. Alyamovskii, G. P. Shveikin, E. N. Shchetnikov and P. V. Geld

Zh. Prikl. Khim. 42 [3], 693-94 (1969) 
I. Books

1. High temperatures-high pressures (An international journal)

Edited by E. Fitzer for high temperatures (Inst. Chem. Tech., Univ. Karlsruhe, W. Germ.) and J. Lees for high pressures (Std. Telecomm. Labs., Harlow, Essex, Engl.)

Plon, London, 1969 (six issues); £15.0.0 (\$36 U. S.) per annum; one-half rate for individuals

2. Ionization potentials, appearance potentials and heats of formation of gaseous positive ions

J. L. Franklin and J. G. Dillard (Rice Univ.), H. M. Rosenstock, J. T. Herron and K. Drax 1 (Nat. Bur. Std.), and F. H. Field (Esso Res. \& Eng. Co.)

NSRDS-NBS-26, U. S. Govt. Printing Office, 1969, \$1.25

3. Kinetics of reactions in ionic systems. Vo1. 4 of Materials Science Research (Proc. Int. Symp. Special Topics in Ceramics, 1967, Alfred, Univ.)

Ed. by T. J. Gray and V. D. Fréchette

Plenum, 1969, $571 \mathrm{p}, \$ 27.50$

4. Refractory metal alloys-metallurgy and technology (Proc. Symp. Met.

Tech. Refractory Meta1s, 1968, Washington, D. C.)

Ed. by I. Machlin, R. T. Begley and E. D. Weisert

P1enum Press, 1968, 491 p, \$22.50 
A. Spectroscopy of interest to high temperature chemistry

1. Photoionization of cadmium and mercury vapors.

Berkowitz, J.; Lifshitz, C. (Argonne Nat. Lab., Argonne, Ill.). Proc. Phys. Soc., London, At. Mol. Phys. 1968, [2] 1(3), 438-40.

2. Reactions of metal atoms. I. The combinations of mercury and chlorine atoms and the dimerization of mercurous chloride. Horne, D. G.; Gosavi, R.; Strausz, O. P. (Univ. Alberta, Edmonton, Alberta).

J. Chem. Phys. 1968, 48(10), 4758-64 (Eng).

3. Morse Franck-Condon factors and $r$-centroids for the so B $3-X^{3} \Sigma^{-}$ system.

Smith, I. W. M. (Univ. Cambridge, Cambridge, Engl.).

J. Quant. Spectrosc. Radiat. Transfer 1968, 8(7), 1437-41 (Eng).

4. Theoretical investigations of the oscillator strengths in the $\mathrm{nx}$-mp series of the alkali metals.

Kancerevicius, A.; Zilionyte, S. (Inst. Phys. Math., Vilnyus USSR) .

Liet. Fiz. Rinkinys, Liet. TSR Mokslu Akad., Liet. TSR Aukst. Mokyklos 1967, 7(1), 73-83 (Russ). CA Vol. 69, 47647 (1968).

5. Determination of the refractive index of argon and of the oscillator strengths of its resonance lines.

Chashchina, G. I.; Gladushchak, V. I.; Shreider, E. Ya. (USSR). Opt. Spektrosk. 1968, 24(6), 1008-10 (Russ). CA Vol.69, 47650 (1968).

6. Synthetic profiles of $\mathrm{C}_{3}$ cometary emissions.

Denis-Gausset, L.; Sauval, A. J. (Univ. Liege, Liege, Belg.).

Bull. Soc. Roy. Sci. Liege 1968, 37(1-2), 48-54 (Fr).

7. Level-crossing experiment to investiate the hyperfine structure of the $6 \mathrm{~s} 6 \mathrm{p} 3 \mathrm{Pl}_{1}$ level of $\mathrm{Ba} I$ spectrum.

Von Oppen, Gebhard (Tech. Univ. Berlin, Berlin, Ger.).

Z. Phys. 1968, 213(3), 254-60 (Ger).

8. Synthetic quartz with high ultraviolet transmission.

Ballman, A. A.; Dodd, D. M.; Kuebler, N. A.; Laudise, R. A.; Wood, D. L.; Rudd, D. W. (Bell Teleph. Lab., Inc., Murray Hill, N. J.) .

Appl. Opt. 1968, 7(7), 1387-90 (Eng). 
A. 9. Effective interactions between d electrons in the second spectra of the iron group.

Shadmi, Y.; Oreg, J.; Stein, J. (Hebrew Univ., Jerusalem, Israel)。 J. Opt. Soc. Amer. 1968, 58(7), 909-14 (Eng).

10. The infrared spectrum of $\mathrm{CrH}$ and $\mathrm{CrD}$.

O'Connor, S. (Univ. Coll., Dublin, Ireland).

Proc. Roy. Irish Acad., Sect. A 1967, 65(-10), 95-111 (Eng).

1l. Widths and transition probabilities of argon lines studied with a plamsa Jet.

Chapelle, J.; Sy, A.; Cabannes, F.; Blandin, J. (Lab. Exchanges Therm., Bellevue-Meudon, Fr.).

J. Quant. Spectrosc. Radiat. Transfer 1968, 8(5), 1201-16 (Fr).

12. Scattering theory of pressure broadening of rotational and vibration-rotation transitions.

Trindle, C. O.; Illinger, K. H. (Tufts Univ., Medford, Mass.). J. Chem. Phys. 1968, 48(10), 4415-26 (Eng).

13. Rotational and vibration-rotation line shifts and widths. Distorted-wave approximation.

Illinger, K. H.; Trindle C. O. (Tufts Univ., Medford, Mass.). J. Chem. Phys. 1968, 48(10), 4427-41 (Eng).

14. Dependence of the moment of the electronic transition, $R_{e}$, on the internuclear spacing, $r$, for the Meinel band system of $\mathrm{N}_{2}{ }^{+}$ion. Koppe, V. T.; Koval, A. G.; Gritsyna, V. V.; Fogel, Ya. M. (USSR). Opt. Spektrosk. 1968, 24(5), 821-3 (Russ). CA Vol. 69, 47798 (1968).

15. Evidence for the $3 \triangle_{u} \rightarrow \beta 3 I I_{g}$ transition in nitrogen. Wu, H. L.; Benesch, W. (Univ. of Maryland, College Park, Md.). Phys. Rev. 1968, 172(1), 31-5 (Eng).

16. Far infrared radiation of xenon plasma from high-pressure lamps. Filippov, O. K. ; Ukhanov, E. V. (USSR). Opt. Spektrosk. 1968, 24(4), 648-50 (Russ). CA Vol. 69, 47823 (1968).

17. An experimental determination of the oscillator strengths for some transition in the Lyman bands of molecular hydrogen. Raddad, G. N.; Lokan, K. H.; Farmer, A. J. D.; Carver, J. H. (Adelaide Univ., Adelaide, Aust.).

U. S. Clearinghouse Fed. Sci. Tech. Inform. 1967, AD 661986, 21 pp. (Eng). Avail. CFSTI. From U. S. Govt. Res. Develop. Rep. 1968, 68(2), 62. 
A. 18. Absorption line series and autoionization resonance structure analysis in the ultraviolet spectrum of strontium $I$.

Parkinson, William H.; Reeves, Emond M.; Grasdalen, Gary; Garton, William R. S.; Codling, Kenneth (Harvard Coll. Obs., Cambridge, Mass.).

U. S. Clearinghouse Fed. Sci. Tech. Inform. 1967, AD 661354 45 pp. (Eng). Avail. CFSTI. From U. S. Govt. Res. Develop Rep. 1968, 68(2), 58.

19. Electronic quenching and the rotational relaxation rate of $\mathrm{OH}^{*}$ $\left(2 \Sigma^{+}\right)$produced by the vacuum-ultraviolet photo-decomposition of water.

Kaneko, Motohisa; Mori, Yuji; Tanaka, Ikuzo (Tokyo Inst. Technol., Tokyo, Japan).

J. Chem. Phys. 1968, 48(10), 4468-73 (Eng).

20. The excitation of the $6^{I_{P_{1}}}$ and $6^{3} P_{0,1,2}$ states of mercury by electron impact.

McConnell, J. C.; Moiseiwitsch, B. L. (Queen's Univ. Belfast, N. Ireland).

Proc. Phys. Soc., London, At. Mol. Phys. 1968, [2] 1(3), 406-13.

21. Ionization states of some unidentified lines in nitrogen.

Fink, Uwe (Univ. of Arizona, Tucson, Ariz.).

J. Opt. Soc. Amer. 1968, 57(7), 937-40 (Eng).

22. Shock-tube measurements of absolute gf-values for neutral and . singly ionized titanium.

Boni, A. A. Jr. (Univ. of California, La Jolla, Calif.). J. Quant. Spectrosc. Radiat. Transfer 1968, 8(7), 1385-97 (Eng).

23. Some new applications of electrodeless lamps in atomic absorption spectrophotometry.

Ivanov, N. P.; Kozyreva, G. V. (USSR).

Vestn. Mosk. Univ., Ser. II. 1968, 23(2) 127-30 (Russ). CA Vol. 47914 (I968).

24. Isolation and detection of atomic resonance lines. Sullivan, J. V.; Walsh, A. (Div. Chem. Phys., C. S. I. R. O., Melbourne, Aust.).

Appl. Opt. 1968, 7(7), 1271-80 (Eng).

25. Sharp and diffuse series in the spectrum of atomic aluminum. Borje, Karl; Eriksson, S.; Isberg. H. Bengt S. (Univ. Lund, Lund, Swed.).

Ark. Fys. 1967, 33(39), 593-5 (Eng). 
A. 26. Additions to the normal term system of the spectrum of atomic oxygen, $O I$.

Isberg, Bengt (Univ. Lund, Lund. Swed.).

Ark. Fys. 1967, 35(40), 495-8 (Eng).

27. Absorption in the vicinity of the $\mathrm{Mg}$ I-resonance line $=2852 \mathrm{~A}$. in the King-type furnace.

Edelhof, Bert; Kusch, Hans Juergen; Lochte-Holtgreven, Walter (Inst. Exp. Phys. Kiel, Kiel, Ger.).

Rev. Roum. Phys. 1968, 13(2), 125-35 (Ger).

28. Rotational analysis of the A-X bands of lead chloride molecule. Singh, O. N.; Singh, I. S. (Banaras Hindu Univ. Varanasi, India). Curr. Sci. 1968, 37(10), 282-3 (Eng).

29. Emission spectrum of the $\mathrm{BeBr}$ molecule excited in the presence of argon.

Reddy, Y. P.; Rao, P. T. (Andhra Univ., Waltair, India). Proc. Phys. Soc., London, At. Mol. Phys. 1968, [2] 1(3), 482-4 (Eng). See CA 68: 82839w.

30. Fine-structure analysis and isotope-effect studies in B-X, C-X, and D-X system of SbO molecule.

Rao, D. V. Krishna; Rao, P. Tiruvenganna (Andhra Univ., Visakhapatnam, India).

Curr. Sci. 1968, 37(11), 310 (Eng).

31. Feasibility of using a uranium hollow cathode lamp as primary source in atomic absorption spectroscopy.

Rossi, G.; Omenetto, N. (Eur. At. Energy Community, Ispra, Italy). Communaute Eur. Energ. At.-EURATOM 1967, EUR-3558.e 12 pp. (Eng). Avail. Dep. From Nucl. Sci. Abstr. 1967, 21(13), 42870.

32. Isotope shift studies of the high-pressure carbon bands. Dhumwad, R. K.; Narasimham, V. A. (Spectrosc. Div., Bhabha At. Res. Center, Trombay, India).

Can. J. Phys. 1968, 46(10)(Pt. 1), 1254-5 (Eng).

33. Emission spectrum of $\mathrm{SiBr}^{+}$molecule.

Kuznetsova, L. A.; Kuz'menko, N. E.; Kuzyakov, Yu. Ya. (USSR). Opt. Spektrosk. 1968, 24(5), 812-14 (Russ). CA Vol. 69, 47972 (1968).

34. Fluorescence spectra of the excited ion $\mathrm{N}_{2}{ }^{+}$resulting from vacuum ultraviolet photon impact on molecular nitrogen. Judge, D. L.; Weissler, G. L. (univ. of Southern California, Los Angeles, Calif.).

J. Chem. Phys. 1968, 48(10), 4590-6 (Eng). 
A. 35. The $b^{l_{\Sigma}}{ }^{+}-\mathrm{X}^{3} \Sigma^{-}$band system of so.

Colin, R. (Nat. Res. Counc. Canada, Ottawa, Can.).

Can. J. Phys. 1968, 46(13), 1539-46.

36. The Swan System of the $\mathrm{C}_{2}$ molecule and the spectrum of the $\mathrm{HgH}$ molecule (Berkeley Analyses of Molecular Spectra, Vol. 2). Phillips, John G.; Davis, Summer P. (Univ. of California

Press; Berkeley, Calif.). 1968. 260 pp.

37. Metastable states of multiply charged ions.

Dmitriev, I. S.; Nikolaev, V. S.; Teplova, Ya. A. (Moscow State Univ., Moscow, USSR).

Phys. Lett., A 1968, 27(2), 122-3.

38. Measured shifts of cesium atomic lines: correlation with electron density derived from widths.

Majkowski, R. F.; Donohue, R. J. (Res.Lab., Gen.Motors Corp., Warren, Mich.).

Phys. Rev. 1968, 173(1), 177-83.

39. The problem of the uniqueness of the $R_{e}\left(r v^{\prime} v^{\prime \prime}\right)$ function for the $\left(A^{2} \sum-X{ }^{2} \Sigma\right)$ system of AlO.

Tawde, N. R.; Korwar, V. M. (Marathwada Univ., Aurangabad, India).

Proc. Phys. Soc., London, At. Mol. Phys. 1968, [2] 1(4), 753-4.

40. Spectral distribution of atomic oscillator strengths.

Fano, U.; Cooper, J. W. (Univ. of Chicago, Chicago, Ill.).

Rev. Mod. Phys. 1968, 40(3), $441-507$.

41. Modern polarizing light filters.

Faerman, G. P. ; Godina, D. A.; Savko. S. S.

Opt.-Mekh. Prom. 1967, 34(12), 49-54 (Russ). CA Vol. 69, $55743 z$ (1968).

42. Computer method for the automatic reduction of spectroscopic data.

Ditzel, Earle F.; Giddings, Lorraine E., Jr. (Nov. Res. Lab., Washington, D.C.).

U.S. Clearinghouse Fed. Sci. Tech. Inform. 1968, AD 665281, 86 pp. Avail. CFSTI. From U.S. Govt. Res. Develop. Rep. 1968, $68(7), 136$.

43. Iarge vibration-rotation interaction effects in calculated Franck-Condon factors.

Villarejo, D.; Stockbauer, R.; Inghram, M. (Univ. of Chicago, Chicago, Ill.).

Chem. Phys. Lett. 1968, 2(1), 11-13. 
A. 44. Franck-Condon factors and r-centroids for some bands of $\mathrm{SrH}$ [strontium hydride].

Singh, P. D.; Srivastava, Y. P. (Univ. Gorakhpur, India). J. Quant. Spectrosc. Radiat. Transfer 1968, 8(7), 1443-6.

45. Avoided crossings in bound potential-energy curves of diatomic molecules: derivation and analysis of the vibrational Hamiltonian.

Lewis, J. K.; Hougen, J. T. (Carleton Univ•, Ottawa, Can.). J. Chem. Phys. 1968, 48(12), 5329-36.

46. Oscillator strength of the molecular hydrogen $(4,0)$ Lyman band. Hesser, James E.; Brooks, Neil H.; Lawrence, George M. (Princeton Univ. Observ., Princeton, N.J.).

Astro-phys. J. 1968, 153(1)(Pt. 2), I65-I66.

47. Experimental oscillator strengths for the O I lines $\lambda \lambda 1302-1306$ and $1152 \mathrm{~A}$.

Gaillard, Michel; Hesser, James E. (Princeton Univ. Observ., Princeton, N.J.).

Astrophys. J. 1968, 152(3)(Pt. 1), 695-700.

48. Relative strengths of resonance lines in the neon $I$ and argon I isoelectronic sequences.

Murphy, P. W. (Univ. of Maryland, College Park, Md.).

Astrophys. J. 1968, 153(1)(Pt. 1), 301-6.

49. Aligned excitation of metastable $6 \mathrm{~s} 5 \mathrm{~d}$ levels in $\mathrm{Ba}$ I spectra and measurement of the $\mathrm{gJ}_{\mathrm{J}}$ values.

Von Oppen, Gebhard (Tech. Univ. Berlin, Berlin, Ger.).

z. Phys. 1968, 213(3), 261-72 (Ger).

50. Oscillator strengths of lines in the spectra of atoms and ions of the carbon and silicon isoelectronic series.

Gruzdev, P. F. (USSR).

Opt. Spektrosk. 1968, 24(6), 860-5 (Russ). CA Vol. 69, 55811v (1968).

51. Calculation of Franck-Condon factors with Poeschl-Teller

wavefunctions. I. Probability of some vibrational transitions in the $D^{I} \Sigma_{u}^{+}-B^{I} I I$ band system of molecular $\mathrm{He}_{2}$.

Zhirnov, N. I. ; Shadrin, O. P. (USSR).

Opt. Spektrosk. 1968, 24(6), 890-5 (Russ). CA Vo1. 69, 55813x (1968). 
A. 52. Some electronic transition probabilities in $\mathrm{CO}$ and $\mathrm{CN}$. Moore, John H., Jr.; Robinson, Dean W. (Johns Hopkins Univ., Baltimore, Md.).

J. Chem. Phys. 1968, 48(11), 4870-4.

53. Attenuation cross sections of mono- and diatomic xenon near resonance line 1469.6 A.

Shardanand (Meas. and Instrum. Tech. Lab., IIASA, Cambridge, Mass.).

J. Quant. Spectrosc. Radiat. Transfer 1968, 8(8), 1533-6.

54. Probabilities of intercombination transitions in series of zinc I, cadmium I, and lead III atoms.

Kancerevicius, A. (Inst. Fiz. Mat., Vi.Inyus, USSR).

Liet. Fiz. Rinkinys, Liet. TSR Mokslu Akad., Liet. TSR Aukst. Mokyklos 1967, 7(2), 32l-7 (Russ). CA Vol. 69, 55828f (1968).

55. Rotational line intensities in $3 \Sigma-\Sigma l$ electronic transitions. Watson, James K. G. (Univ. Reading, Reading, Engl.).

Can. J. Phys. 1968, 46(14), 1637-43 (Eng).

56. Criteria for maximizing steady-state population of the lowest excited triplet state.

Henry, Bryan R.; Kasha, Michael (Florida State Univ., Tallahassee, Fla.).

J. Mol. Spectrosc. 1968, 26(4), 536-42 (Eng).

57. A method for improved resolution of level-crossing curves: application to the hyperfine structure of the level $3^{2} \mathrm{P}_{3} / 2$ in atomic sodium.

Copley, G.; Kibble, B. P.; Series, G. W. (Univ. Windsor, Windsor, Ont.).

Proc. Phys. Soc., Iondon, At. Mol. Phys. 1968, [2] 1(4), 724-35.

58. Optical transition probabilities of the configurations 3 p54s$3 \mathrm{p} 55 \mathrm{p}$ of argon $I$.

Wende, B. (Phys. Tech. Bundesanst. Braunschweig, Braunschweig, Ger.).

Z. Phys. 1968 213(4), 341-51 (Ger).

59. Forced resonance effects in potassium vapors.

Movsesyan, M. E.; Badalyan, N. N. ; Iradyan, V. A. (Erevansk Gos. Univ., Erevan).

Dokl. Akad. Nauk Arm. SSR 1967, 45(3), 118-20 (Russ). See CA 68: 118428c. CA Vol. 69, 55836 (1968). 
A. 60. Analysis of autoionization resonance structure in the spectrum of calcium vapor.

Newsom, G. H.; Shore, B. W. (Harvard Coll. Observ., Cambridge, Mass.).

Proc. Phys. Soc., London, At. Mol. Phys. 1968 [2] 1(4), 742-4.

61. Matrix-isolation study of the reaction of $F_{2}$ and of $F$ atoms with NCN. The infrared spectra of the species NF2CN and FNCN. Milligan, Dolphus E.; Jacox, Marilyn E. (Nat. Bur. of Stand., Washington, D. C.).

J. Chem.Phys. 1968, 48(11), 4811-16.

62. Ultraviclet absorption spectrum of germanium monoxide molecule. Majumdar, K.; Mohan, Hari (Univ. Allahabad, Allahabad, India). Indian J. Pure Appl. Phys. 1968, 6(4), 183-6.

63. Ultraviolet emission spectrum of CaBr molecule. Reddy, Y. Prabhakara; Rao, P. Tiruvenganna (Andhra Univ., Waltair, India).

Indian J. Pure Appl. Phys. 1968, 6(4), 181-2.

64. High-resolution vacuum ultraviolet absorption spectra of the $\mathrm{B}+\Sigma^{I}-\mathrm{X}^{1} \Sigma^{+}, \mathrm{C}^{1} \Sigma^{+}-\mathrm{X}^{1} \Sigma^{+}$, and $\mathrm{j}^{3 \Sigma^{+}-\mathrm{X}^{1} \Sigma^{+}}$transitions in carbon monoxide.

Tilford, S. G.; Vanderslice, Joseph T. (Nav. Res. Lab., E. 0. Hulburt Center for Space Res., Washington, D. C.).

J. Mol. Spectrosc. 1968, 26(4), 419-31.

65. Measurement of the oscillator strength of the silicon monoxide

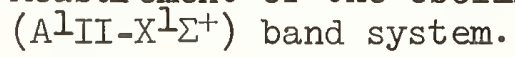

Main, R. P.; Morsell, A. L.; Hooker, W. J. (Heliodyne Corp., Van Iruys, Calif.).

J. Quant. Spectrosc. Radiat. Transfer 1968, 8(8), 1527-32.

66. Absorption coefficients for water vapor in the 600-1000-cm.-1 Varanasi, P.; Chou, S.; Penner, S. S. (State Univ. of New York, Stony Brook, N. Y.).

J. Quant. Spectrosc. Radiat. Transfer 1968, 8(8), 1537-41.

67. Broadening the 2537-A. Hg line due to vapors of some metals. Zav'yalov, G. I.; Zav'yalov, G. I.; Zav'yalova, A. Yu.; Prilezhaeva, N. A.; Belyaev, M. P.; Gileva, M. V.; Grudanov, V. S.

Izv. Vyssh. Ucheb. Zavod., Fiz. 1968, 11(3), 156-8 (Russ). CA Vol. 69, 55967 (1968). 
A. 68. Absorption bands of $\operatorname{SrH}$ and $\operatorname{SrD}$ in the ultraviolet region. Khan, M. Aslam; Butt, M. R. (Univ. Karachi, Karachi, Pakistan). Proc. Phys. Soc., London, At. Mol. Phys. 1968, [2]1(4), 745-50.

69. Estimation of the position of an intensity maximum in an absorption band.

Lesk, A. M.; Vark. A. (Princeton Univ., Princeton, N. J.). Proc. Phys. Soc., London, Atom. Mol. Phys. 1968, [2] 1(4) $752-3$.

70. Rydberg adsorption series and ionization energies of the oxygen molecule. I.

Yoshino, K.; Tanaka, Y. (Office of Aerosp. Res., Air Force Cambridge Res. Lab., Bedford, Mass.).

J. Chem. Phys. 1968, 48(11), 4859-67.

71. Analysis of two systems of bands due to $I_{\triangle} \rightarrow I_{I I}$ and $3 \Sigma \rightarrow 3_{I I}$ transitions of the methylidyne cation, $\mathrm{CH}^{+}$.

Carre, Michel; Dufay, Maruice (Lab. Phys. Atmos., Fac. Sci. Lyon, Villeurbanne, Fr.).

C. R. Acad. Sci., Paris, Ser. A, B 1968, 266(21), 1367-9 (Fr).

72. High-energy satellites in the vacuum ultraviolet spectra of beryllium II and beryllium IV.

Frankel, B. S.; Goldsmith, S.; Feldman, U. (Hebrew Univ., Jerusalem, Israel).

Phys. Lett., A 1968, 27(2), 111-12.

73. Determination of cross sections for the quenching of resonance radiation of metal atoms. IV. Lithium.

Jenkins, D. R. (Thernton Res. Centre, "Shell" Res. Itd., Chester, Engl.).

Proc. Roy. Soc., Ser. A 1968, 306 (1486), 413-21 (Eng).

74. Decay of the first positive group of molecular nitrogen and the asundi bands of carbon monoxide.

Hartfuss, H. J.; Schmillen A. (Univ. Giessen, Giessen, Ger.). Z. Naturforsch., A 1968, 23(5), 722-6 (Ger).

75. Consequences of photoselection on the intensity and polarization of luminescent molecules.

Kalantar, A. H. (Univ. Alberta, Edmonton, Alberta). J. Chem. Phys. 1968, 48(11), 4992-6.

76. Conservation of hertzian coherence in sensitized fluorescence. Cheron, Bernard; Barrat, Jean Pierre (Lab. Spectrosc. At., Fac. Sci., Caen, Fr.).

C. R. Acad. Sci., Paris, Ser. A, B 1968, 266B(20), 1324-7 (Fr). 
A. 77. Microwave rotational spectrum of silicon monoxide. Toerring, T. (Freie Univ. Berlin, Berlin, Ger.). Z. Naturforsch., A 1968, 23(5), 777-8 (Ger).

78. One band system in the discharge spectrum in lanthanum trifluoride vapors.

Shenyavskaya, E. A.; Gurvich, L. V.; Mal'tsev, A. A. (USSR). Opt. Spektrosck. 1968, 24(6), 1025-6 (Russ). CA Vol. 69, 56070 (1968).

79. High-resolution study of electron-impact spectra of kinetic energies between 33 and $100 \mathrm{eV}$. and scattering angles of $16^{\circ}$. Lassettre, Edwin N.; Skerbele, Ausma; Dillon, Michael A.; Ross, Kevin J. (Carnegie-Mellon Univ., Pittsburgh, Pa.). J. Chem. Phys. 1968, 48(11), 5066-96.

80. Role of cascade transitions in the excitation of the $4 \mathrm{~s} 5 \mathrm{~s} 3 \mathrm{~s}_{1}$ level of zinc and of the $5 \mathrm{~s} 6 \mathrm{~s}^{3} \mathrm{~S}_{1}$ level of cadmium. Klyucharev, A. N. (USSR).

Opt. Spektrosk. 1968, 24(6), 1017-20 (Russ), CA Vol. 69, 56074 (1968).

81. Determination of the natural linewidth and the effective cross sections of quenching collisions by the total absorption method.

Frish, S. E.; Makarov, A. P. (USSR).

Opt. Spektrosk. 1968 24(5), 831-2 (Russ). CA Vol. 69, 56075 (1968).

82. Determination of the lifetimes of atomic states. Bakos, Jozsef (Kozp. Fiz. Kut. Int., Hung.). Fiz. Szemie 1968, 18(4), 100-5 (Hung).

83. Theory of atomic structure including electron correlation. Sinanoglu, Oktay; Oksuz, Iskender (Yale Univ., New Haven, Conn.).

Phys. Rev. Lett. 1968, 21(8), 507-11.

84. Calculation of the potential functions of several excited singlet states of hydrogen, deuterated hydrogen, and deuterium molecules. Monfils, A. (Univ. Liege, Liege, Belg.). Bull. Cl. Sci., Acad. Roy. Belg. 1968, 54(I), 44-80 (Fr).

85. Potential energy curves and issociation energies of some diatomic molecules.

Laud, B. B.; Kalsulkar, D. R. (Marathwada Univ., Aurangabad, India) .

Indian J. Phys. 1968, 42(I), 50-4. 
A. 86. Possible existence of double minima in potential energy surfaces of $\mathrm{AB}_{2}$-type molecules.

Hayes, Edward F.; Pfeiffer, Gary V. (Princeton Univ., Princeton, N. J.).

J. Amer. Chem. Soc. 1968, 90(18), 4773-7.

87. Time dependence of the population of $3 \mathrm{p}^{0}$ and $l_{\mathrm{p}} \mathrm{O}$ neon atoms during postluminescence of this gas subjected to pulsed centimeter waves.

Bouvier, Annie; Bouvier, Albert; Janin, Joseph (Univ. Lyon, Lyons, Fr.).

C. R. Acad. Sci., Paris, Ser. A, B 1968, 266B (26), 1571-4 (Fr).

88. Isotopic shifts and hyperfine structure of the 1850-A. resonance line of mercury.

Lecler, Daniel (Lab. Opt., Fac. Sci., Caen, Fr.).

C. R. Acad. Sci., Paris, Ser. A,B 1968, 266B (25), 1509-12 (Fr).

89. Theory of dissociative recombination.

Bardsley, J. N. (Univ. Manchester, Manchester, Engl.) •

Proc. Phys. Soc., London, At. Mol. Phys. 1968, [2] 1(3), 365-80.

90. Use in optics of techniques of delayed coincidences between cascade transitions. Measurement of the lifetime and of population and depopulation rates of the $7^{3} \mathrm{~S}_{1}$ mercury level. Pardies, Jean (Lab. Phys. Exp., Fac. Sci. Bordeaux, Talence, Fr.)

C. R. Acad. Sci., Paris, Ser. A B 1968, 266B(26), 1586-8 (Fr).

91. Improved values for energy levels, Ritz standards, and interferometrically measured wavelengths, in thorium $I$.

Valero, Francisco P. J. (Univ. Nac. La Plata, La Plata, Argent.) J. Opt. Soc. Amer. 1968, 58(8), 1048-53.

92. Observation and interpretation of the $\mathrm{O}_{2}\left({ } \triangle_{\mathrm{g}}-3 \Sigma_{\mathrm{g}}{ }^{-}\right)$airglow emissions.

Gattinger, R. I. (Nat. Res. Counc. Canada, Ottawa, Can.). Can. J. Phys. 1968, 46(14), 1613-26.

93. Forbidden lines of neutral sulfur in the Fraunhofer spectrum. Swensson, J. W. (Univ. Lund, Lund, Swed.).

Z. Astrophys. 1968, 68(2), 151-5.

94. Photodissociation of $\mathrm{C}_{2}$ molecules in the atmosphere of comets. Mokhnach, D. O. (Gl. Astron. Observ., Pulkovo, USSR). Dokl. Akad. Nauk SSSR 1968, 180(4), 817-20 (Russ). CA Vol. 69 63129 (1968). 
A. 95. New spectrum of the $\mathrm{SiO}^{+}$molecule.

Nagaraj, S.; Verma, R. D. (Univ. New Brunswick, Fredericton, New Brunswick).

Can. J. Phys. 1968, 46(14), 1597-602.

96. Excited electronic states of the $\mathrm{NO}^{+}$ion.

Huber, K. P. (Nat. Res. Counc. Canada, Ottawa, Can.).

Can. J. Phys. 1968, 46(15), 1691-5.

97. Identification method for interpreting vibrational strucutures of diatomic molecules.

Kovalenok, G. V. (Tomsk. Politekh. Inst. im. Kirova, Tomsk. USSR) .

Izv. Vyssh. Ucheb. Zaved., Fiz. 1968, 11(5), 130-2 (Russ). CA Vol. 69, 63208 (1968).

98. Precision measurements of the hyperfine splittings in the optical spectrum of indium hydride.

Larsson, T.; Neuhaus, H.; Aslund, N. (Univ. Stockholm, Stockholm Swed.).

Ark. Fys. 1968, 37(13), 141-9.

99. Absorption coefficients of $\mathrm{O}_{4}$ at oxygen windows.

Shardanand (Electron, Res. Center, Cambridge, Mass.).

INASA Tech. Note 1967, TN D-4225, 6pp.

100. Properties of iodine uv counters.

Cose, V. (Univ. Zurich, Zurich, Switz.).

Rev. Sci. Instrum. 1968, 39(7), 1055-6.

101. Lithium-fluoride overcoated aluminum mirrors with highest reflectance in the vacuum ultraviolet.

Cox, J. T.; Hass, G.; Waylonis, J. E. (Night Vision Lab., U. S. Army Electron. Command, Fort Belvior, Va.).

App1. Opt. 1968, 7(8), 1535-40.

102. Hyperfine structure and lifetimes of the $4^{2} \mathrm{P}_{3} / 2$ and $5^{2} \mathrm{P}_{3} / 2$ states of potassium-39.

Schmieder, Robert W.; Iurio, Allen; Happer, W. (Columbia Univ., New York, N. Y.).

Phys. Rev. 1968, 173(1), 76-9.

103. Ultraviolet absorption spectrum of germanium (II) fluoride. Hauge, R.; Khanna, V. M.; Margrave, J. L. (Rice Univ., Houston, Tex.).

J. Mol. Spectrose. 1968, 27(1-4), 143-7. 
A. 104. New band system of CS [carbon monosulfide] in the near ultraviolet region.

Tewarson, A.; Palmer, H. B. (Pennsylvania State Univ., University Park, Pa.).

J. Mol. Spectrosc. 1968, 27(104), 246-51.

105. Effect of modulations of orientation and alignment of the ground state of the atom on the dispersion and absorption properties of mercury-20l vapor.

Laloe, Franck; Leduc, Michele; Minguzzi, Paolo (Ecole Norm. Super, Paris, Fr.).

C. R. Acad. Sci., Paris, Ser. A, B 1968, 266B(25), 1517-20 (Fr).

106. Forbidden lines in the psectrum of tin $I$.

Kornalewski, T.; Niewodniczanski, H. (Jagellonian Univ., Cracow, Poland).

Acta Phys. Pol. 1967, 32(1), 197-9.

107. Rotational structure of the 2650-2850-A. system of the BiF molecule.

Mohanty, R. S.; Rai, D. K.; Upadhya, K. N.; Singh, N. L. (Banaras Hindu Univ., Varanasi, India).

Proc. Phys. Soc., London, At. Mol. Phys. 1968, [2] 1(3), $532-4$.

108. Atomic emission lines below 2000 angstroms. Hydrogen through argon.

Kelly, Raymond I. (Nav. Res. Lab., Washington, D. C.). U. S. Clearinghouse Fed. Sci. Tech. Inform., AD. 1968, AD 666545, 356 pp. (Eng). Avail. CFSTI. From U. S. Govt. Res. Develop. Rep. 1968, 68(9), 64 .

109. Hyperfine-splitting factors of some antimony I levels. Kopff, M.; Les. F.; Les, Z.; Malczyk, B. (Jagellonian Univ., Cracow, Poland).

Acta Phys. Pol. 1967, 31(4), 781-2.

110. Triplet to singlet excitation of carbon $v$ ions in hightemperature plasmas.

Prasad, A. N.; El-Menshawy, M. F. (Univ. Liverpool, Liverpool, Engl.).

Proc. Phys. Soc., London, At. Mol. Phys. 1968, [2] 1 (3), 471-8.

111. Microwave spectrum of the ClO [chlorine monoxide] radical. Amano, Takayoshi; Hirota, Eizi; Morino, Yonezo (Univ. Tokyo, Tokyo, Japan).

J. Mol. Spectrosc, 1968, 27 (1-4), 257-65. 
A. 112. Level-crossing signal line shapes andordering of energy levels. Stroke, H. H.; Fulop, G.; Klepner, S.; Redi, O. (New York Univ., New York, N. Y.).

Phys. Rev. Lett. 1968, 21(2), 61-4 (Eng).

113. Atomic term patterns.

Judd, B. R. (Johns Hopkins Univ., Baltimore, Md.).

Phys. Rev. 1968, 173(1), 39-40 (Eng).

114. Oscillator strengths of resonance lines of Ge I, As II; Sn I, $\mathrm{Sb} I I$; and $\mathrm{Pb} \mathrm{I}, \mathrm{Bi}$ II.

Gruzdev, P. F. (USSR).

Opt. Spektrosk. 1968, 25(1), 3-11 (Russ). CA Vol. 69, 63432 (1968).

115. Design characteristics of a phase fluorometer for the study of lifetimes of molecules.

Pant, D. D.; Srivastava, B. N.; Sharma, V. K.; Tripathi, H. B. (D. S. B. Govt. Coll., Naini Tal, India).

Indian J. Pure Appl. Phys. 1968, 6(5), 236-8 (Eng).

116. Tables of Molecular Vibrational Frequencies, Pt. 3. Shimanouchi, T. (U. S. Govt. Printing Office: Washington D. C.). $196839 \mathrm{pp}$.

117. The Detection and Measurement of Infra-Red Radiation (Monographs on the Physics and Chemistry of Materials). 2nd ed.

Smith, R. A.; Jones, F. E. (Oxford Univ. Press: Iondon). $1968503 \mathrm{pp}$.

118. Molecular beam studies of scandium monofluoride.

Green, David W. (Lawrence Rad. Lab., Univ. of California, Berkeley, Calif.).

U. S. At. Energy Comm. 1968, UCRL-17961, 79 pp. (Eng).

Avail. Dept.: CFSTI. From Nucl. Sci. Abstr. 1968, 22(11), 21056.

119. Rotational and vibrational excitation of molecular ions by electrons.

Boikova, R. F.; Ob'edkov, V. E. (Ieningrad. Gos. Univ.,

Leningrad, USSR).

Zh. Eksp. Teor, Fiz. 1968, 54(5), 1439-44 (Russ).

CA Vol. 69, 69740 (1968).

120. Excitation of molecular oxygen by low-energy electrons. Skubenich, V. V. (USSR).

Opt. Spektrosk. 1968, 25 (1), 169-70 (Russ), CA Vol. 69 69741 (1968). 
A. 121. Vibrational-vibrational-translational energy transfer between two diatomic molecules.

Zelechow, Ann; Rapp, Donald. Sharp, Terry E. (Polytech. Inst. of Brooklyn, Brooklyn, N. Y.).

J. Chem. Phys. 1968, 49(1), 286-99 (Eng).

122. Photoionization of the $\mathrm{H}_{2}$ molecule near threshold. Chupka, William A.; Berkowitz, Joseph (Argonne Nat. Lab., Argonne, IIl.).

J. Chem. Phys. 1968, 48(12), 5726-8 (Eng).

123. Autoionization phenomenon observed in the experimental study of the ionization of krypton by impact of monoenergetic electrons. Peresse, J.; Tuffin, F.; Le Coz, G. (Fac. Sci. Brest. Brest, Fr.).

Phys. Lett., A 1968 27(6), 356-7 (Fr).

124. Inverted population in dissociation of cesium bromide molecules. Berry, R. Stephen; Cernoch, Thomas; Coplan, Michael; Ewing, James J. (Univ. of Chicago, Chicago, Ill.). J. Chem. Phys. 1968, 49(1), 127-34 (Eng).

125. First ionization potential of nitrogen dioxide. Natalis, P.; Collin, J. E. (Univ. Liege, Liege, Belg.). Chem. Phys. Lett. 1968, 2(2), 79-82 (Eng).

126. Dependence of the concentration of metastable helium and neon atoms on the parameters of a hollow-cathode discharge. Znamenskii, V. B. (USSR).

Opt. Spektrosk. 1968, 25(1), 17-23 (Russ), CA Vol. 69, 71669 (1968).

127. Experimental spectroscopy.

Dieke, G. H. (Johns Hopkins Univ., Baltimore, Md.).

Phonons, Perfect. Lattices, Lattice Point Imperfections, Scot. Univ. Summer Sch., 6th Aberdeen, Scot. 1965 (Pub. 1966), 269-313 (Eng).

128. Lifetimes of the metastable states of the helium-like ions. Senashenko, V. S.; Teku, B. (USSR).

Vestn. Mosk. Univ., Fiz., Astron, 1968, 23(3), 120-2 (Russ). CA Vol. 69, 72273 (1968).

129. Effect of pumping light filtration conditions on the frequency of the 0-0 transition of rubidium-87 atoms.

Alekseev, E. I.; Bazarov, E. N.; Grigor'ev, V. I. (USSR). Radiotekh. Elektron, 1968, 13(6), 1041-4 (Russ). CA Vol. 69, 72274 (1968). 
A. 130. Optical pumping of neon metastable $\left(3 \mathrm{P}_{2}\right)$ atoms.

Schearer, I. D. (Texas Instrum. Inc., Dallas, Tex.).

Phys. Rev. Lett. 1968, 21(10), 660-1 (Eng).

131. Vibrational levels of a diatomic molecule.

Rush, D. G. (Sir Juhn Cass Coll., London, Engl.).

Trans. Faraday Soc. 1968, 64(8), 2013-16 (Eng).

132. Determination of the electron transfer moment of the first positive system of nitrogen $\mathrm{N}_{2}(1+)$ bands.

Egorov, V. N.; Tunitskii, I. N.; Cherkasov, E. M. (USSR). Zh. Prikl. Spektrosk. 1968, 8(3), 479-88 (Russ). CA Vol. 69, 72501 (1968).

133. Unfolding spectrometer slit broadening effects from spectra. Berreman, D. W. (Bell Teleph. Lab., Inc., Murray Hill, N. J.). Appl. Opt. 1968, 7(8), 1447-53 (Eng).

134. Measuring the absolute energy distribution in a spectrum of xenon light sources.

Kekhlibarov, T.; Zschaeck, H.

Izv. Fiz. Inst. ANEB, Bulg. Akad. Nauk. 1968, 17, 217-31 (Bulg).

135. Emission spectrum of vo molecule.

Laud, B. B.; Kalsulkar, D. R. (Marathwada Univ., Aurangabad, India).

Indian J. Phys. 1968, 42(1), 61-71 (Eng).

136. Fluroescence of nitric oxide. V. Mean lifetime in the $D^{2} \Sigma^{+}$ state.

Callear, A. B.; Pilling, M. J.; Smith, I. W. M. (Phys. Chem. Lab., Cambridge, Engl).

Trans. Faraday Soc. 1968, 64(9), 2296-103 (Eng).

137. Electron collision cross sections and generalized oscillator strengths for potassium.

Hertel, I. V.; Ross, K. J. (Southampton Univ., Southampton, Engl).

Proc. Phys. Sco., London, At. Mol. Phys. 1968, [2] 1(4), 697704 (Eng).

138. Electronic configurations and nitrogen-14 quadrupole and hyperfine couplings in the $\Sigma$ states of $\mathrm{CN}$.

Purcell, Keith F. (Kansas State Univ., Manhattan, Kans.). J. Chem. Phys. 1968, 48(12), 5735-6. (Eng). 
B. Reactions between gases and condensed phases

1. Accurate thermogravimetry in flowing gases.

Sharp, W. B. A.; Mortimer, D. (Cent. Elec. Res. Lab., Leatherhead, Engl.).

J. Sci. Instrum. 1968, [2] I(8), 843-6 (Eng).

2. Boron and Boron carbide by vapor deposition.

Donaldson, James G.; Stephenson, James B.; Cochran, Andrew A. (Rolla Met. Res. Center, Bur. of Mines, Rolla, Mo.).

U. S. Bur. Mines, Rep. Invest. 1968, No. 7150, 15 pp. (Eng).

3. Solubility of nitrogen in liquid iron and liquid iron-carbon alloys. Gomersall, D. W.; McLean, A.; Ward, R. G. (Inland Steel Co., East Chicago, Indiana).

Trans. Met. Soc. AIME (Amer. Inst. Mining, Met., Petrol. Eng.) 1968, 242(7), 1309-15 (Eng).

4. Kinetics of oxygen effusion from induction-stirred liquid silver. Utine, M. T.; Parlee, N. A. D. (Stanford Univ•, Stanford, Calif.). Trans. Met. Soc. AIME (Amer. Inst. Mining, Met., Petrol. Eng.) 1968, 242(7), 1458-60 (Eng).

5. Oxidation behavior of niobium up to $1000^{\circ}$.

Bollenrath, F.; Poddey, P. (Rhein.-Westf. Tech. Hochsch. Aachen, Aachen, Ger.).

Metall (Berlin) 1968, 22(7), 702-6 (Ger).

6. Photoionization of high-temperature vapors. II. Sulfur molecular species.

Berkowitz, J.; Lifshitz, C. (Argonne Nat. Lab., Argonne, IIl.). J. Chem. Phys. 1968, 48(10), 4346-50 (Eng).

7. Diffusion in three-component gas mixtures in the transition region between Knudsen and molecular diffusion.

Cunningham, R. S.; Geankoplis, C. J. (Ohio State Univ., Columbus, Ohio).

Ind. Eng. Chem., Fundam. 1968, 7(3), 429-32 (Eng).

8. Vapor pressure of thallium and activity measurements on liquid silver-thallium alloys by the torsion effusion method.

Desre, Pierre J.; Hawkins, Donald T.; Hultgren, Ralph (Univ. Grenoble, Grenoble, Fr.).

Trans. Met. Soc. AIME (Amer. Inst. Mining, Met., Petrol, Eng.) 1968, 242(7), 1231-2 (Eng).

9. Production of electrons from alkaline earths in flames: equilibrium and kinetic considerations. Jensen, D. E. (AeroChem Res. Lab., Inc., Princeton, N. J.) . Combust. Flame 1968, 12(3), 261-8 (Eng). 
B. 10. Thermochemical Kinetics, Methods for the Estimation of Thermochemical Data and Rate Parameters. Benson, Sidney W. (Wiley: New York). 1968. 223 pp.

11. Ruthenium dioxide-oxygen-ruthenium tetroxide equilibrium.

Penman, B. D.; Hammer, R. R. (Idaho Nucl. Corp., Idaho Falls, Idaho).

U. S. At. Energy Comm. 1968, IN-1013, 7 pp. (Eng). Avail. Dep.; CFSTI. From Nucl. Sci. Abstr. 1968, 22(8), 15251.

12. Anomalies in the equilibrium of the reaction of solid cuprous sulfide with gaseous hydrogen to yield solid copper and gaseous hydrogen sulfide. Arndt, D.; Kordes, E. (Univ. Bonn, Bonn, Ger.). Z. Anorg. Allg. Chem. 1968, 359(1-2), 1-13(Ger).

13. Reduction equilibrium of nickel-magnesium olivines. Abbattista, Fedele. Atti Accad. Sci. Torino. Cl. Sci. Fis., Mat. Natur. 1966, 100, 191-9(Ital). From CZ 1967, (51/52), Abstr. No. 523.

14. Reduction equilibrium of cobalt-magnesium olivines. Abbattista, Fedele.

Atti Accad. Sci. Torino. Cl. Sci. Fis., Mat. Natur. 1966, 100, 255-63 (Ital). From CZ 1967, (51/52), Abstr. No. 524.

15. Transpiration vapor pressure measurements for the molten salt systems lead chloride + cesium chloride and cadmium chloride + cesium chloride.

Bloom, H.; Hastie, J. W. (Univ. Tasmania, Hobart, Aust.). J. Phys. Chem. 1968, 72(7), 2361-5 (Eng).

16. Entropy of gaseous polyatomic ions at various temperatures. Krestov, G. A. (Ivanov. Khim.-Tekhnol. Inst., Ivanovo, USSR). Zh. Fiz. Khim. 1968, 42(4), 866-73 (Russ). CA Vol. 69, 46543 (1968).

17. The growth of gold films on rocksalt in high vacuum. Henning, C. A. O. (Univ. Witwatersrand, Johannesburg, S. Africa). Surface Sci. 1968, 9(2), 277-95 (Eng).

18. The rhodium-mercury system.

Jangg, Gerhard, Kirchmayr, Hans Rudolf; Mathis, H. B. (Tech. Hochsch, Vienna, Austria).

Z. Metallk. 1967, 58(10), 724-6 (Ger). 
B. 19. Preparation of silicon tetraiodide, some of its thermodynamic properties, and some experiments on the crystal growth of silicon by the disproportionation reaction of silicon diiodide.

20. The vacuum stability of $A^{I I I_{B} V}$ compounds.

Mironov, K. E.; Brygalina, G. P.; Eikhe, S. N. (Inst. Neorg. Khim., Novosibirsk, USSR).

Izv. Sib. Otd. Akad. Nauk SSSR, Ser. Khim. Nauk 1967, No. 5, 114-15 (Russ) CA Vol. 69, 46987 (1968).

21. Effect of molecular association on the electrical conductivity of sodium vapor.

Leckenby, R. E.; Robbins, E. J. (Reactor Eng. Lab., U. K. At. Energy Auth., Risley/Warrington, Engl.).

Proc. Phys. Soc., London, At. Mol. Phys. 1968, [2]1(3), 441-4 (Eng).

22. Mass-spectrometric study of photoionization. IX. Hydrogen cyanide and acetonitrile.

Dibeler, Vernon H.; Liston, Susan K. (Int. for Basic Stand., Nat. Bur. of Stand., Washington, D. C.).

J. Chem. Phys. 1968, 48(10), 4765-8 (Eng).

23. Mass-spectrometer study of metal-containing flames.

Milne, Thomas A.; Greene, Frank T. (Midwest Res. Inst., Kansas City, Mo.).

U. S. Clearinghouse Fed. Sci. Tech. Inform., AD 1968, AD 664832; 25 pp. (Eng). Avail. CFSTI. From U. S. Govt. Res. Develop. Rep. 1968, 68(7), 149.

24. Reaction of equilibrium of $2 \mathrm{CrCl}_{3}$ (solid. gas) $+\mathrm{Cl}_{2}$ (gas) $=\mathrm{CrCl}_{4}$ (gas). Oppermann, H. (Deut. Akad. Wiss. Berlin, Berlin, Ger.). Z. Anorg. Allg. Chem. 1968, 359(1-2), 51-7 (Ger).

25. Reaction of silicon dioxide with silicon carbide at $1870-2670^{\circ} \mathrm{K}$. Borisov, V. G. (USSR).

Tr. Vses. Inst. Nauch.-Issled. Proekt. Rab. Ogneupor. Prom. 1967, No. 39, 128-45 (Russ). CA Vol. 69, 48877 (1968).

26. Saturated vapor pressure of cesium.

Volyak, I. D.; Vinogradov, Yu. K.; Anisimov, V. M. (Mosk. Aviats, Inst., Moscow, USSR)

Teplofiz. Vys. Temp. 1968, 6(3), 545-7 (Russ) CA Vol.69, 54499 (1968). 
B. 27. Arsenic selenide vapor pressure.

Gorbov, S. I.; Krestovnikov, A. N. (Mosk. Inst. Stali Splavov, Moscow, USSR)

Zh. Neorg. Khim. 1968, 13(6), 1482-7 (Russ). CA Vol. 69, 54502 (1968).

28. Partition functions and thermodynamic properties to high temperatures for $\mathrm{H}_{3}{ }^{+}$and $\mathrm{H}_{2}{ }^{+}$.

Patch, R. W.; McBride, Bonnie J. (Lewis Res. Center, Cleveland, Ohio).

NASA (Nat. Aeronaut. Space Admin.) Tech. Note 1968, (TN D-4523), 73 pp. (Eng). Avail. CFSTI 3 dollars.

29. Experimental study of the $\mathrm{K}_{2} \mathrm{O}-\mathrm{Al}_{2} \mathrm{O}_{3}-\mathrm{SiO}_{2}-\mathrm{H}_{2} \mathrm{O}$ system at $340-760^{\circ}$ and $\mathrm{P}=\mathrm{P}_{\mathrm{H}} \mathrm{O}=1000 \mathrm{~kg} \cdot / \mathrm{cm}$ ?

Zharikov, V. A.; Ivanov, I. P.; Fonarev, V. I.; Dyuzhikova, T. N.; Shmonov, V. M. (Inst. Geol. Rud. Mestorozh. Petrogr. Mineral. Geokhim., Moscow, USSR) .

Dokl. Akad. Nauk SSSR 1968, 180(4), 955-7 (Russ). CA Vol.69, 54698 (1968).

30. The system nickel-hydrogen at high pressures of gaseous hydrogen. Baranowski, Bogdan; Bochenska, Krystyna; Majchrzak, Stanislaw (Polska Akad. Nauk, Warsaw, Poland).

Rocz. Chem. 1967, 41(12), 2071-82 (Eng).

31. Carbon monoxide equilibrium pressure of niobium-oxygen-carbon solid solutions.

Fromm. Eckehard; Spaeth, Gernot (Max-Planck-Inst. Metallforsch., Stuttgart, Ger.).

Z. Metallk. 1968, 59(1), 65-8 (Ger).

32. Phase diagram of the niobium-oxygen system.

Fromm, E.; Jehn, H. (Max-Planck-Inst. Metallforsch., Stuttgart, Ger.).

J. Less-Common Metals 1968, 15(2), 242-3 (Eng).

33. Equilibration in the dissociation of solid solutions of iron titanate and magnesium titanate.

Shchepetkin, A. A.; Antonov, V. K.; Dvinin, V. I.; Chufarov, G.I. (Inst. Met., Sverdlovsk, USSR).

Dokl. Akad. Nauk SSSR 1968, 180(3), 672-4 (Russ). CA Vol. 69, 54917 (1968).

34. Mechanism of epitaxial crystallization from an atomic beam. Dorfman, V. F.; Trusov, I. I. (Inst. Elektron. Upravlyayushchikh Mash., Moscow, USSR).

Kristallografiya 1968, 13(3), 502-7 (Russ). CA Vol. 69, 55012, (1968). 
B. 35. Mechanism of epitaxial crystallization from an atomic beam. Dorfman, V. F.; Trusov, L. I. (Inst. Elektron. Upravlyayushchikh Mash., Moscow, USSR).

Kristallografiya 1968, 13(3), 502-7 (Russ). CA Vol. 69, 55012, (1968).

36. Selected values of electric dipole moments for molecules in the gas phase.

Nelson, Ralph D., Jr.; Lide, David R.; Maryott, Arthur A. (Middlebury Coll., Middlebury, Vt.).

Nat. Stand. Ref. Data Ser., Nat. Bur. Stand. (U.S.) 1967, No. 10, $49 \mathrm{pp}$. (Eng).

37. Modifications of the oxygen potential diagram for the system iron-calcium-oxygen.

Reeve, D. A.; Gregory, A. G. (Univ. Birmingham, Birmingham, Engl.). Inst. Mining Met. Trans. Sect. C 1967, 76(Dec.), 273-7 (Eng).

38. Sensitive and versatile differential vapor pressure apparatus. Farm, R. J. Bruckenstein, Stanley (Univ. of Minnesota, Minneapolis, Minn.).

Anal. Chem. 1968, 40(11), 1651-7 (Eng).

39. Gold-wire seals for ultrahigh vacuum.

Hawrylak, Roman A. (Univ. of Rochester, Rochester, N. Y.). U. S. Clearinghouse Fed. Sci. Tech. Inform., PB Rep. 1967, PB 177429, 19 pp. (Eng). Avail. CFSTI. From U. S. Govt. Res. Develop. Rep. 1968, 68(9), 140.

40. Mass-spectrometric study of desulfurization of certain iron alloys by vacuum melting.

Kato, E.; Fukube, Y. (Waseda Univ., Waseda, Japan).

Cast Metals Res. J. 1968, 4(2), 105 (Eng).

41. Activity of oxygen in liquid iron.

Omori, Yasuo; Suzuki, Kenichiro; Aratani, Fukuo; Sanbongi, Koji (Tohoku Univ., Sendai, Japan).

Tohoku Daigaku Senko Seiren Kenkyusho Iho 1967, 23(2), 129-36 (Japan). CA Vol. 69, 60958 (1968).

41. Activity of oxygen in liquid iron-chromium and iron-vanadium alloys.

Omori, Yasuo; Sanbongi, Koji (Tohoku Univ., Sendai, Japan). Tohoku Daigaku Sendo Seiren Kenkyusho Iho 1967, 23(2), 129-36 (Japan). CA Vol. 69, 60959 (1968).

42. Hydrogen solubility in liquid iron alloys.

Bagshaw, T.; Mitchell, A. (Univ. Sheffield, Sheffield, Engl.). J. Iron Steel Inst. (London) 1967, 205(7), 769-71 (Eng). 
B. 43. Change of chemical potential of oxygen in liquid metals and liquid oxide phases.

Goto, Kazuhiro; Sasabe, Minoru; Someno, Mayumi (Tokyo Inst. Technol., Tokyo, Japan).

Trans. Met. Soc. AIME (Amer. Inst. Mining, Met., Petrol. Eng.) 1968, 242(8), 1757-9 (Eng).

44. Evidence for molecular dimers, $\left(I_{2}\right)_{2}$, in iodine vapor.

Passchier, A. A.; Gregory, N. W. UUniv. of Washington, Seattle, Wash.).

J. Phys. Chem. 1968, 72(8), 2697-702(Eng).

45. Measurement of the saturated vapor pressure of strontium chloride. Naryshkin, I. I.; Glazov, V. I.; Kharlamov, V. M. (Leningrad. Politekh. Inst. im. Kalinina, Leningrad, USSR).

Zh. Prikl. Khim. (Leningrad) 1968, 41(6), 1329-32 (Russ). CA Vol. 69, 61689 (1968).

46. Calculation of vapor pressure during Knudsen Measurements in instances of complete dissociation of evaporating compounds. III. General formula for the calculation.

Pashinkin, A. S. (USSR).

Zh. Fiz. Khim. 1968, 42(6), 1511-12 (Russ). CA Vol. 69, 61690 (1968).

47. Partial vapor pressures of components of rubidium bromide-cesium bromide and rubidium iodide-cesium iodide solid solutions at $650-850^{\circ} \mathrm{K}$.

Makarov, L. L.; Stupin, D. Yu. (Leningrad. Gos. Univ. im. Zhdanova, Leningrad, USSR) .

Zh. Fiz. Khim. 1968, 42(6), 1508-11 (Russ). CA Vol. 69, 61691 (1968).

48. Vapor pressure of potassium to $2170^{\circ} \mathrm{K}$.

Bowles, Kenneth J. (Lewis Res. Center, Cleveland, Ohio). INASA Tech. Note 1968, NASA TN D-4535, 11 pp. (Eng). Avail. CFSTI.

49. Realization of quantitative differential thermal analysis.

II. A solid-gas reaction.

Speros, D. M.; Woodhouse, R. L. (Lighting Res. Lab., Gen Elec. Co., Cleveland, Ohio).

J. Phys. Chem. 1968, 72(8), 2846-51 (Eng).

50. Iron-sulfur system. I. Growth rate of ferrous sulfide on iron and diffusivities of iron in ferrous sulfide.

Turkdogan, E. T. (Edgar C. Bain Lab. for Fundam. Res., U. S. Steel Corp., Monroeville, Pa.).

Trans. Met. Soc. AIME (Amer. Inst. Mining, Met., Petrol. Eng.) 1968, 242(8), 1665-72 (Eng). 
B. 51. Iron-sulfur system. II. Rate of reaction of hydrogen sulfide with ferrous sulfide.

Worrell, W. L.; Turkdogan, E. T. (Univ. of Pennsylvania, Philadelphia, Pa.).

Trans. Met. Soc. AIME (Amer. Inst. Mining, Met., Petrol. Eng.) 1968, 242(8), 1673-8 (Eng).

52. Reduction of molybdenum oxides by means of hydrogen.

Iordanov, Kh. V.; Nikolov, T. G.; Chimbulev, M. T. (Bulg.). Neue Huette 1968, 13(4), 215-18 (Ger).

53. Determination of the limits of the phases of the uraniumoxygen system by oxygen transfer. Phase diagram for oxygen-touranium ratios of $2.19-2.63$ at $1080-1200^{\circ}$.

Kotlar, Alain; Gerdanian, Paul; Dode, Maurice (Lab. Chim. Thermodyn. Fac. Sci. Orsay, Orsay, Fr.).

J. Chim. Phys. Physicochim. Biol. 1968, 65(4), 687-91 (Fr).

54. High-temperature solubility of nitrogen in molybdenum.

Fromm, E.; Jehn, H. (Max-Planck-Inst. Metallforsch., Stuttgart, Ger.).

J. Less-Common Metals 1968, 14(4), 474-5 (Ger).

55. Growth of zinc selenide-zinc telluride solid solutions in $\mathrm{Te}_{2}$ atmosphere.

Aven, M.; Hall, R. B.; Prener, J. S. (Gen. Elec. Res. and

Develop. Center, Schenectady, N. Y.).

J. Electrochem. Soc. 1968, 115(8), 846-50 (Eng).

56. The chemical activities of iron and chromium in binary iron chromium alloys.

Reese, Richard B.; Rapp, Robert A.; St. Pierre, George E. (Ohio State Univ., Columbus, Ohio).

Trans. Met. Soc. AIME (Amer. Inst. Mining, Met., Petrol. Eng.) 1968, 242(8), 1719-26 (Eng).

57. Equilibriums of reactions for reducing calcium molyldate and tungstate by carbon monoxide and carbon.

Zelikman, A. N.; Belyaevskaya, I. V.; Bobylev, V. M. (USSR). Izv. Akad. Nauk SSSR, Metal. 1968, (3), 80-7 (Russ). CA Vol. 69, 62113 (1968).

58. Mass spectrometry of the vapors over $\mathrm{PbCl}_{2}+\mathrm{ACl}$ mixtures $(\mathrm{A}=$ $\mathrm{Na}, \mathrm{K}, \mathrm{Rb}$, or $\mathrm{Cs}$ ). I. Thermodynamic studies. Bloom, H.; Hastie, J.W. (Univ. Tasmania, Hobart, Aust.). J. Phys. Chem. 1968, 72(8), 2706-10 (Eng). 
B. 59. The vapor pressure and thermal stability of gallium sulfide. Lieth, R. M. A.; Heijligers, H. J. M.; Van der Heijden, C. W. M. (Tech. Unv., Eindhoven, Neth.).

Mater. Sci. Eng. 1967, 2(4), 193-200 (Eng).

60. Electron diffraction study of the structure of gaseous selenium and tellurium molecules.

Barzdain, P. P.; Alekseev, N. V. (USSR).

Zh. Strukt. Khim. 1968, 9(3), 520-2 (Russ). CA Vol. 69, 62345 (1968).

61. Effect of an electric field on the ion-molecular reactions of water ion clusters in a gas-dynamic jet. Pozharov, S. L.; Chernov, I. G. (Inst. Yad. Fiz., Tashkent, USSR).

Khim. Vys. Energ. 1968, 2(4), 291-6 (Russ). CA Vol. 69, 62581 (1968).

62. Gas analysis by modulated molecular beam mass spectrometry. Olander, D. R.; Waddel, W. W. (Lawrence Radiat. Lab., Univ. of California, Berkeley, Calif.). Anal. Chem. 1968, 40(11), 1687-93 (Eng).

63. Chemical synthesis by means of radicals formed at high temperatures.

Timms. P. L. (Univ. Bristol, Bristol, Engl.). Endeavour 1968, 27(102), 133-7 (Eng).

64. Equilibrium of the hydrogen reduction of $\mathrm{Nd}_{2} \mathrm{O}_{3} \cdot-3 \mathrm{WO}_{3}$ at $800-1100^{\circ}$. Vasil'eva, I. A.; Mudretsova, S. N.; Kireeva, I. M. (Mosk. Gov. Univ. im. Lomonosova, Moscow, USSR).

Izv. Akad. Nauk SSSR, Neorg. Mater. 1968, 4(8), 1315-18 (Russ). CA Vol. 69, 69076 (1968).

65. Reduction of rubidium fluoride by silicon-calcium.

Zviadadze, G. N.; Shengeliya, O. V.; Tabatadze, L. S.; Vatsadze, D. V. (USSR) .

Izv. Akad. Nauk SSSR, Metal. 1967, (6), 33-7 (Russ).

CA Vol. 69, 69077 (1968)

66. Reduction of tantalum pentachloride by hydrogen on a heated surface.

Polyakov, Ya. M.; Lisovik, I. F.; Krestovnikov, A. N. (USSR) . Izv. Akad. Nauk SSSR, Metal. 1968, (3), 88-93 (Russ).

CA Vol. 69, 69078 (1968). 
B. 67. Solubility of nitrogen in arc-melted and levitation-melted iron and iron alloys.

Uda, Masahiro; Wada, Tsuguyasu.

Trans. Nat. Res. Inst. Metals (Tokyo) 1968, 10(2), 79-91 (Eng).

68. Phase diagram of the copper-oxygen system in the liquid-phase temperature range.

Osterwald, Joerg (Tech. Univ. Berlin, Berlin, Ger.).

Z. Metallik. 1968, 59(7), 573-6 (Ger).

69. Sintering behavior of silicon-carborundum compositions in a carbon monoxide-nitrogen medium.

Sadkovskii, E. P.; Guzman, I. Ya.; Kutukov, V. F.; Tumakova, E. I. (Mosk. Khim.-Tekhnol. Inst. im. Mendeleeva, Moscow, USSR) Izv. Akad. Nauk SSSR, Neorg. Mater. 1968, 4(7), 1186-8 (Russ). CA Vol. 69, 69450 (1968).

70. Intermediate energy molecular beams from free jets of mixed gases. Anderson, J. B. (Princeton Univ., Princeton, N. J.). Entropie 1967, No. 18, 33-7 (Eng).

71. Microwave discharge source for atomic and molecular beam production. Brink, Gilbert 0.; Fluegge, Robert A.; Hull, Robert J. (Cornell Aeronaut. Lab., Buffalo, N. Y.). Rev. Sci, Instrum. 1968, 39(8), 1171-2 (Eng).

72. Molecular beam studies of scandium monofluoride. Green, David W. (Lawrence Radiat. Lab., Univ. of California, Berkeley, Calif.).

U. S. At. Energy Comm. 1968, UCRL-17961, 79 pp. (Eng).

73. Dissociation energies of bismuth-antimony molecules. Kohl, Fred J.; Carlson, K. Douglas (Case Western Reserve Univ. Cleveland, Ohio).

J. Amer. Chem. Soc. 1968, 90 (18), 4814-17 (Eng).

74. New method for preparing thin layers in quasithermodynamic equilibrium.

Haymann, P.; Trillat, J. J. (Fac. Sci., Rouen, Fr. ). Vide 1967, 22(127), 1-6 (Fr).

75. Kinetic energy of molecules that traverse an excess-energy Barrier during sublimation. Mar, Raymond W.; Searcy, Alan W. (Lawrence Radiat. Lab., Univ. of California, Berkeley, Calif.).

J. Chem. Phys. 1968, 49(I), 182-5 (Eng). 
B. 76. Comment on the composition of selenium vapor.

Berkowitz, J.; Chupka, W. A. (Argonne Nat. Lab., Argonne, Ill.). J. Chem. Phys. 1968, 48(12), 5743-4 (Eng).

77. Saturated vapor pressure of solid antimony telluride.

Boncheva-Mladenova, Z.; Pashinkin, A. S.; Novoselova, A. V.

(Mosk. Gos. Univ. im. Lomonosova, Moscow, USSR). .

Izv. Akad. Nauk SSSR, Neorg. Mater. 1968, 4(8), 1211-15 (Russ). CA Vol. 69, 69874 (1968).

78. Saturated vapor pressure of arsenic sulfides.

Ustyugov, G. P.; Kudryavtsev, A. A.; Kuadzhe, B. M. (USSR).

Izv. Akad. Nauk SSSR, Neorg. Mater. 1968, 4(8), 1338-9 (Russ).

CA Vol. 69, 69875 (1968)

79. Composition of vapor over lead oxide.

Kazenas, E. K.; Chizhikov, D. M.; Tsvetkov, Yu. V. (Inst. Met. im. Baidova, Moscow, USSR).

Dokl. Akad. Nauk. SSSR 1968, 181(1), 158-9 (Russ). CA Vol. 69, 69876 (1968).

80. Chemisorption of carbon monoxide on tantalum monocarbide.

Gasser, R. P. H.; Gowan, P. M.; Newman, D. G. (Phys. Chem. Lab., Oxford, Engl.).

Surface Sci. 1968, Il(2), 317-26 (Eng).

81. Desorption by electron impact: oxygen adsorbed on tungsten. Madey, Theodore E.; Yates, John T., Jr. (Nat. Bur. of Stand. Washington, D. C.).

Surface Sci. 1968, 11(2), 327-51 (Eng).

82. Mass spectrometric investigation of oxygen adsorption on molybdenum single crystal face (100).

Vas'ko, M. P.; Ptushins'kii, Yu. G. (Inst. Fiz., Kiev, USSR). Ukr. Fiz. Zh. (Ukr. Ed.) 1968, 13(2), 344-7 (Ukrain).

CA Vol. 69, 69934 (1968).

83. Dissolciative electronic desorption of carbon monoxide from tungsten.

Coburn, J. W. (Univ. of Minnesota, Minneapolis, Minn.). Surface Sci. 1968, 11(1), 61-81 (Eng).

84. Interaction of oxygen, carbon monoxide, and nitrogen with (0OI) and (110) faces of molybdenum.

Hayek, K.; Farnsworth, H. E.; Park, R. L. (Brown Univ., Providence, R. I.).

Surface Sci. 1968, 10(3), 429-45 (Eng). 
B. 85. What happens during a collision when two molecules collide and react.

Henchman, Michael (Brandeis Univ., Waltham, Mass.). Advan. Sci. 1968, 24(122), 404-18 (Eng).

86. Decomposition of carbon monoxide $2 \mathrm{CO} \rightleftharpoons \mathrm{CO}_{2}+\mathrm{C}$ in the presence of iron.

Meroc, Jean Fabien; Boulle, Andre (Ecole Mines Paris, Paris, Fr.).

C. R. Acad. Sci., Paris, Ser. C 1968, 266(26), 1770-3 (Fr).

87. Tables of bimolecular gas reactions.

Trotman-Dickenson, A. F.; Milne, G. S. (Edward Davies Chem. Lab., Averystwyth, Wales).

Nat. Stand. Ref. Data Ser., Nat. Bur. Stand. (U.S.) 1967, NSRDS-NBS 9, 129 pp (Eng).

88. Kinetics of germanium dioxide reduction by carbon monoxide. Gol'shtein, T. V.; Berezkina, L. G. (USSR).

Met. Tsvet. Redk. Metal., Akad. Nauk SSSR, Inst. Met. 1967, 61-5 (Russ). CA Vol. 69, 70250 (1968).

89. Experimental investigation of chemical reactions of uranium, uranium dioxide, and uranium carbide with air and water vapor in the temperature range from 600 to $1300^{\circ}$.

Poeschel, E.; Skoutajan, R. (Battelle Inst. e. V., Frankfurt/ M., Ger.).

U. S. At. Energy Comm. 1967, (BMwF-FBK-67-13), 112 pp. (Ger.) Avail. Dep. From Nucl. Sci. Abstr. 1967, 21(15), 2581-4.

90. Thermal dissociation of nitrogen and synthesis of ammonia from atomic nitrogen on pure iron.

Tret'yakov, I. I.; Shub, B. R.; Sklyarov, A. V. (Inst. Khim. Fiz., Moscow, USSR).

Dokl. Akad. Nauk SSSR 1968, 181(3), 648-51 (Russ). CA Vol. 69, 70316 (1968).

91. Thermal decomposition of nitrous oxide at high temperatures. Borisov, A. A. (Inst. Khim. Fiz., Moscow, USSR). Kinet. Katal. 1968, 9(3), 482-9 (Russ). CA Vol. 69, 70318 (1968).

92. Carbon monoxide isotope exchange with tantalum monocarbide. Gasser, R. P. H.; Gowan, P. M.; Newman, D. G. (Phys. Chem. Lab., Oxford, Engl.).

Trans. Faraday Soc. 1968, 64(8), 2196-9 (Eng). 
B. 93. Hydration of sodium chloride in aqueous and vapor solutions at high temperatures.

Khaibullin, I. Kh. (Energ. Inst. im. Krzhizhanovskogo, Moscow, USSR).

Teploenergetika 1968, 15(5), 46-9 (Russ). CA Vol. 69, 70375 (1968).

94. Equilibrium composition of the vapor phase of zinc sulfidecadmium sulfide solid solutions during roasting in hydrogen. Bundel, A. A.; Zhukova, V. N. (USSR).

Tr. Mosk. Khim.-Tekhnol. Inst. 1967, No. 54, 19-22 (Russ). CA Vol. 69, 70385 (1968).

95. Indium arsenide-indium phosphide phase diagram.

Ugai, Ya. A.; Goncharov, E. G.; Kitina, Z. V.; Shvyreva, T. N. (Voronezh. Gos. Univ., Voronezh, USSR).

Izv. Akad. Nauk SSSR, Neorg. Mater. 1968, 4(3), 348-51 (Russ). CA Vol. 69, 70398 (1968).

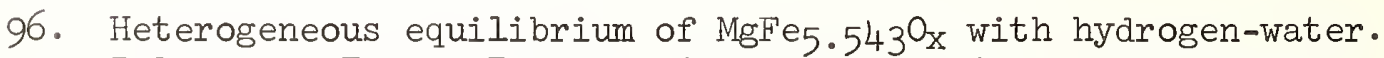
Bulgakova, T. I.; Zaitsev, O. S.; Guzei, A. S.; Tokhtavaeva, G. M. (Mosk. Gos. Univ. im. Lomonosova, Moscow, USSR).

Izv. Akad. Nauk SSSR. Neorg. Mater. 1968, 4(8), 1387-9 (Russ). CA Vol. 69, 70400 (1968).

97. P-T-f 02 [pressure-temperature-oxygen fugacity] relations in the system iron-oxygen-magnesium oxide-silicon dioxide. Speidel, D.H.; Nafziger, R. H. (Pennsylvania State Univ., University Park, Pa.).

Amer. J. Sci, 1968, 266(5), 361-79 (Eng).

98. P-T-fo2 [pressure-temperature-oxygen fugacity] relations for the system iron-oxygen-silicon dioxide.

Lindsley, D. H.; Speidel, D. H.; Nafziger, R. H. (Carnegie Inst. of Washington, Washington D. C.).

Amer. J. Sci. 1968, 266(5), 342-60 (Eng).

99. Diopside melting under conditions of very high water-vapor pressures.

Ryabchikov, I. D. (Inst. Geol. Rud. Mestorozhd. Petrogr. Miner . Geokhim., Moscow, USSR). Dok]. Akad. Nauk SSSR 1968, 181 (1) 207-9 (Russ). CA Vol. 69, 70446 (1968).

100. Preparation of germanium iodide, and determination of its saturated vapor pressure over liquid and solid phases. Chernyaev, V. N.; Chetverikov, N. I.; Kernozhitskii, V. K.; Noak, E. (Mosk. Energ. Inst. im. Lenina, Moscow, USSR). Izv. Akad. Nauk SSSR, Neorg. Mater. 1968, 4(6), 821-4 (Russ). CA Vol. 69, 70466 (1968). 
B. 101. Comparative calculation of physical-chemical properties in correlating data on the solubility of substances in water vapor.

Tskhvirashvili, D. G. (Gruz, Inst. Energ., USSR) . Soobshch. Akad. Nauk Gruz. SSSR 1968, 49(3), 653-8 (Russ). CA Vol. 69, 70476 (1968).

102. Solubility of water in a basalt melt.

Khitarov, N. I.; Kadik, A. A.; Lebedev, E. B. (Inst. Geokhim. Anal. Khim. im. Vernadskogo, Moscow, USSR) . Geokhimiya 1968, (7), 763-72 (Russ). CA Vol. 69, 70478 (1968).

103. Solubility of hydrogen in liquid niobium. Kalinyuk, N. N.; Lakomskii, V. I. (USSR). Izv. Akad. Nauk SSSR, Metal. 1968, (4), 28-32 (Russ). CA Vol. 69 70485 (1968).

104. Chemical equilibria in heterogeneous systems. III. The ironiodine system at higher temperatures.

Bartovska. L.; Bartovsky, T.; Cerny, C. (Vys. Sk. Chem.-Technol., Prague, Czech.).

Collect. Czech. Chem. Commun. 1968, 33(8), 2355-62 (Eng).

105. Transfer of $\mathrm{ZnSiP}_{2}$ during chemical transport reactions in an iodide system.

Valov, Yu. A.; Ushakova, T. N. (Fiz.-Tekh. Inst. im. Ioffe, Leningrad. USSR).

Izv. Akad. Nauk SSSR, Neorg. Mater. 1968, 4(7), 1054-9 (Russ). CA Vol. 69, 70668 (1968).

106. Thermodynamics and kinetics of preparing carbon-titanium carbide system alloys by precipitation from a gas phase.

Kilin, V. S.; Evstyukhin, A. I.; Dergunova, V. S. (Mosk. Inzh.Fiz. Inst., Moscow, USSR).

Zh. Fiz. Khim. 1968, 42(3), 785-92 (Russ). CA Vol. 69, 70725 (1968).

107. Vapor-gas mixture (silicon tetrachloride, argon) and (molybdenum pentachloride, helium) of a given composition for the preparation of MoSi coatings.

Lysov, B. S.; Shimbarevich, V. A. (Mosk. Inst. Stali Splavov, Moscow, USSR).

Izv. Akad. Nauk SSSR, Neorg. Mater. 1968, 4(4), 506-9 (Russ). CA Vol. 69, 70760 (1968). 
B. 108. Thermodynamic properties of solid chromium-aluminum alloys at $1000^{\circ}$.

Johnson, W.; Komarek, K.; Miller, E. (New York Univ., New York, N. Y.).

Trans. Met. Soc. AIME (Amer. Inst. Mining, Met., Petrol. Engl.) 1968, 242(8), 1685-8(Eng).

109. Thermodynamic activity of components of a solid solution of cobalt(II) and iron(II) oxides at $1000^{\circ}$.

Dobrovinskii, R. Yu.; Balakirev, V. F.; Men, A. N.; Chufarov, G. I. (Inst. Met., Sverdlovsk, USSR).

Zh. Fiz. Khim. 1968, 42(4), 1001-3 (Russ). CA Vol. 69, 70796 (1968).

110. Thermodynamics of the dissociation of magnesium copper ferrites. Shchepetkin, A. A.; Antonov, V. K.; Chufarov, G. I. (Inst. Met., Sverdlovsk, USSR).

Izv. Akad. Nauk SSSR, Neorg. Mater. 1968, 4(7), 1156-9 (Russ). CA Vol. 69, 70801 (1968).

1l1. A thermodynamic study of liquid manganese-tin alloys.

Spencer, P. J.; Pratt, J. N. (Univ. Birmingham, Birmingham, Engl.). Trans. Met. Soc. AIME (Amer. Inst. Mining, Met., Petrol. Eng.) 1968, 242(8), 1709-11 (Eng).

112. Some thermodynamic characteristics of the reduction and formation of $\mathrm{MnFe}_{2} .065 \mathrm{O}_{\mathrm{x}}$.

Rozanov, A. G.; Bulakova, T. I.; Zaitsev, O. S. (Mosk. Gos. Univ. im. Lomonosova, Moscow, USSR).

Izv. Akad. Nauk SSSR, Neorg. Mater. 1968, 4(8), 1385-6 (Russ). CA Vol. 69, 70803 (1968).

113. Thermodynamic properties of solid rhodium-palladium alloys. Myles, K. M. (Met. Div., Argonne Nat. Lab. Argonne Ill.). Trans. Met. Soc. AIME (Amer. Inst. Mining, Met., Petrol. Eng.) 1968, 242(8), 1523-6 (Eng).

114. Mass-spectrometric study of the thermodynamic properties of the sodium fluoride-beryllium fluoride system.

Belousov, V. I.; Sidorov, I. N.; Akishin, P. A. (USSR).

Izv. Sib. Otd. Akad. Nauk SSSR, Ser. Khim. Nauk 1968, (1), 131-6 (Russ). CA Vol. 69, 70810 (1968).

115. Gaseous metal nitrides. II. The dissociation energy, heat of sublimation, and heat of formation of zirconium mononitride. Gingerich, Karl A. (Battelle Mem. Inst., Columbus, Ohio). J. Chem. Phys. 1968, 49(1), 14-18 (Eng). 
B. 116. Gaseous metal nitrides. III. Dissociation energy of thorium mononitride and predicted dissociation energies of diatomic Group III-VI transition-metal nitrides. Gingerich, Karl A. (Battelle Mem. Inst., Columbus, Ohio). J. Chem. Phys. 1968, 49(1), 19-24 (Eng).

117. Dissociation pressure of cadmium selenite.

Bakeva, S. S.; Buketov, E. A.; Pashinkin, A. S. (Khim.-Met. Inst., Karaganda, USSR).

Zh. Neorg. Khim. 1968, 13(7), 1779-81 (Russ). CA Vol. 69, 70846 (1968).

118. Melting point and saturated vapor pressure of neptunium tetrachloride.

Choporov, D. Ya.; Chudinov, E. G. (USSR). Radiokhimiya 1968, 10(2), 221-7 (Russ). CA Vol. 69, 70849 (1968).

119. Behavior of germanium telluride during distillation in vacuum. Karbanov, S. G.; Pashinkin, A. S.; Salamatin, B. A.; Zlomanov, V. P.; Novoselova, A. V. (Mosk. Gos. Univ. im. Lomonosova, Moscow, USSR).

Izv. Akad. Nauk SSSR Neorg. Mater. 1967, 3(10), 1793-6 (Russ). CA Vol. 69, 70967 (1968).

120. Fractionation of nickel-chromium-copper-aluminum alloys during vacuum evaporation.

Swift, Robert A.; Noval, Barry A.; Merz, Kenneth M. (IRC, Inc. Philadelphia, Pa.)

J. Vac. Sci. Technol. 1968, 5(3), 79-83 (Eng).

121. An electron diffraction investigation of the structure of zirconium tetrafluoride in the vapor phase.

Spiridonov, V. P. (USSR).

Vestn. Mosk. Univ., Khim. 1968, 23(1), 113-14 (Russ). CA Vol. 69, 71358 (1968).

122. Mass Spectrometry in Science and Technology. White, F. A. (Wiley: New York). $1968352 \mathrm{pp}$.

123. Thermodynamic and electrical properties of combustion gas and its phasma. I. Theoretical calculations. Mori, Yasuo; Ohtake, Kazutomo; Yamanoto, Mitsuyoshi; Imani, Kazutake (Tokyo Inst. Technol., Tokyo, Japan). Bull. JSME (Jap. Soc. Mech. Eng.) 1968, 11(44), 241-52 (Eng). 
B. 124. Ideality of the uranium carbide-uranium nitride solid solutions. Leitnaker, J. M. (Metals and Ceram. Div., Oak Ridge Nat. Lab., Oak Ridge, Tenn.).

Thermodyn. Nucl. Mater., Proc. Symp., Vienna 1967 (Pub. 1968) 317-30 Eng). From Nucl. Sci. Abstr. 1968, 22(15), 31468.

125. Stable composition range and decomposition pressure of uranium carbide-uranium nitride solid solution. Sano, T.; Katsura, M.; Kai, H. (Osaka Univ., Osada, Japan). Thermodyn. Nucl. Mater., Proc. Symp., Vienna 1967 (Pub. 1968), 301-15 (Eng). From Nucl. Sci. Abstr. 1968 22(15), 31466. 


\section{Announcement of New Bibliographies on the High Temperature Chemistry and Physics of Materials}

Superintendent of Documents, Government Printing Office, Washington, D.C. 20402

Dear Sir:

Please add my name to the announcement list of new publications to be issued in the series: National Bureau of Standards Special Publication 315 .

Name

Company

Address

City

State

Zip Code

(Notification Key N-380) 


\section{Announcement of New Bibliographies on the High Temperature Chemistry and Physics of Materials}

Superintendent of Documents, Government Printing Office, Washington, D.C. 20402

\section{Dear Sir:}

Please add my name to the announcement list of new publications to be issued in the series: National Bureau of Standards Special Publication 315 .

Name

Company

Address

City

State

Zip Code

(Notification Key N-380) 
